\title{
Agency Costs, Charitable Trusts, and Corporate Control: Evidence from Hershey's Kiss-Off
}

\section{Citation}

Robert H. Sitkoff \& Jonathan Klick, Agency Costs, Charitable Trusts, and Corporate Control: Evidence from Hershey's Kiss-Off, 108 Colum. L. Rev. 749 (2008).

\section{Permanent link}

http://nrs.harvard.edu/urn-3:HUL.InstRepos:14976044

\section{Terms of Use}

This article was downloaded from Harvard University's DASH repository, and is made available under the terms and conditions applicable to Other Posted Material, as set forth at http:// nrs.harvard.edu/urn-3:HUL.InstRepos:dash.current.terms-of-use\#LAA

\section{Share Your Story}

The Harvard community has made this article openly available.

Please share how this access benefits you. Submit a story.

\section{Accessibility}


ISSN 1936-5349 (print)

ISSN 1936-5357 (online)

\title{
HARVARD
}

JOHN M. Olin CENTER FOR LAW, ECONOMICS, AND BUSINESS

\begin{abstract}
AGENCY COSTS, CHARITABLE TRUSTS, AND CORPORATE CONTROL: EVIDENCE FROM HERSHEY'S KISS-OFF
\end{abstract}

Jonathan Klick \& Robert H. Sitkoff

Discussion Paper No. 593

$08 / 2007$

Harvard Law School

Cambridge, MA 02138

This paper can be downloaded without charge from:

The Harvard John M. Olin Discussion Paper Series: http://www.law.harvard.edu/programs/olin_center/

The Social Science Research Network Electronic Paper Collection:

$\underline{\text { http://ssrn.com/abstract=1009353 }}$

This paper is also a discussion paper of the

John M. Olin Center's Program on Corporate Governance. 


\title{
Agency Costs, Charitable Trusts, and Corporate Control: Evidence From Hershey's Kiss-Off
}

\author{
Jonathan Klick* \\ Robert H. Sitkoff**
}

\begin{abstract}
In July of 2002 the trustees of the Milton Hershey School Trust announced a plan to diversify the Trust's investment portfolio by selling the Trust's controlling interest in the Hershey Company. The Company's stock jumped from $\$ 62.50$ to $\$ 78.30$ on news of the proposed sale. But the Pennsylvania attorney general, who was then running for governor, brought suit to stop the sale on the grounds that it would harm the central Pennsylvania community. In September 2002, after the attorney general obtained a preliminary injunction, the trustees abandoned the sale and the Company's stock dropped to $\$ 65.00$. Using standard event study econometric analysis, we find that the sale announcement was associated with a positive abnormal return of over 25 percent and that canceling the sale was followed by a negative abnormal return of nearly 12 percent. Our findings imply that instead of improving the welfare of the needy children who are the Trust's main beneficiaries, the attorney general's intervention preserved charitable trust agency costs on the order of roughly $\$ 850$ million and prevented the Trust from achieving salutary portfolio diversification. Overall, blocking the sale destroyed roughly $\$ 2.7$ billion in shareholder wealth, reducing aggregate social welfare by preserving a suboptimal ownership structure of the Hershey Company. Our findings contribute to the literature of trust law by supplying the first empirical analysis of agency costs in the charitable trust form and by highlighting shortcomings in supervision of charitable entities by the state attorneys general. Our findings also contribute to the literature of corporate governance by measuring the difference in firm value when the Hershey Company was subject to a takeover versus under the control of a controlling shareholder.
\end{abstract}

* Visiting Professor of Law, University of Pennsylvania (Fall 2007); Visiting Professor of Law, Columbia University (Spring 2008); Jeffrey A. Stoops Professor of Law, Florida State University $<$ jklick@law.fsu.edu>.

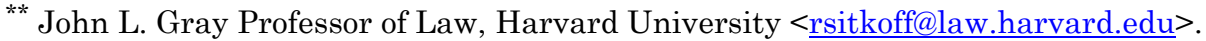

The authors thank Evelyn Brody, John Coates, John Columbo, Harvey Dale, Joel Dobris, Einer Elhauge, Allen Ferrell, Jonah Gelbach, Eric Helland, Adam Hirsch, Edward Iacobucci, Marcel Kahan, Louis Kaplow, Ehud Kamar, Reinier Kraakman, Robert Lawless, John Langbein, James Lindgren, Yair Listokin, Geoffrey Manne, Henry Manne, John McGinnis, Richard Posner, Edward Rock, Larry Ribstein, Dan Rubinfeld, Max Schanzenbach, Kathryn Spier, Mark Weinstein, and workshop participants at FSU, Harvard, Illinois, Northwestern, NYU, and the 2007 Annual Meeting of the American Law and Economics Association for helpful comments and suggestions; Teresa Gallego O'Rourke, Kelley Smith, Shira Tydings, Ethan White, Rachel Zeehandelaar, and Annmarie Zell for superb research assistance; and Harvard Law School and NYU School of Law for financial support. 


\section{Agency Costs, Charitable Trusts, and Corporate Control: Evidence From Hershey's Kiss-Off}

\section{TABLE OF CONTENTS}

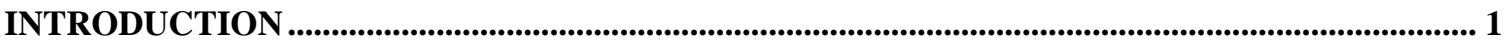

I. MILTON HERSHEY'S CHOCOLATE EMPIRE ................................................................. 8

II. AGENCY COSTS AND THE ABORTED 2002 SALE...................................................... 15

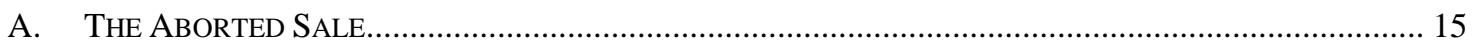

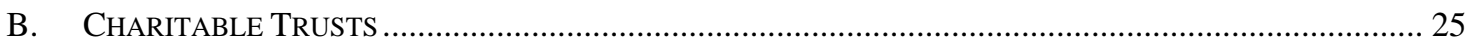

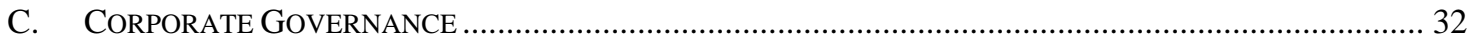

III. EMPIRICAL ANALYSIS .......................................................................................................... 35

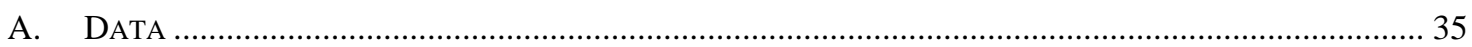

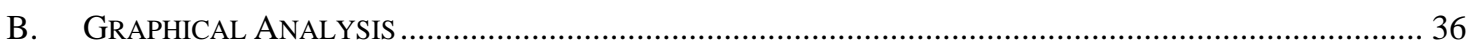

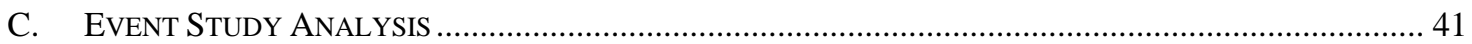

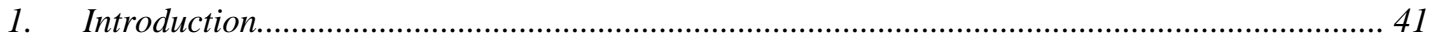

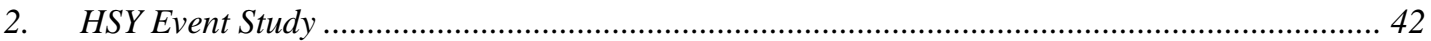

3. Competitor-Based Controls ………………………................................................................ 50

4. The Problem of a Single-Firm Event Study ………............................................................... 54

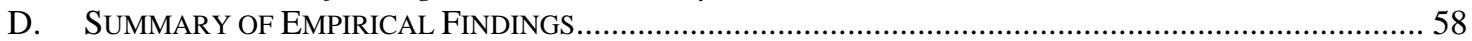

IV. IMPLICATIONS FOR POLICY ANALYSIS..................................................................... 61

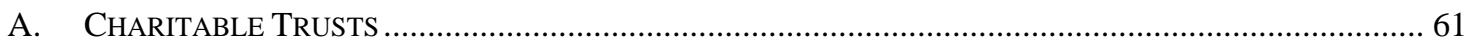

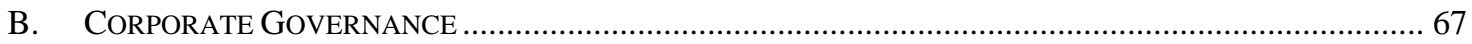

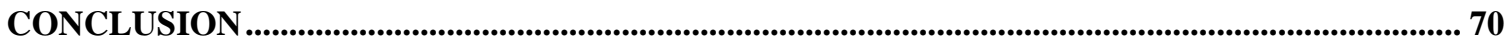

APPENDIX A: EXTENDED PRICE DYNAMIC GRAPHS.......................................................... 72

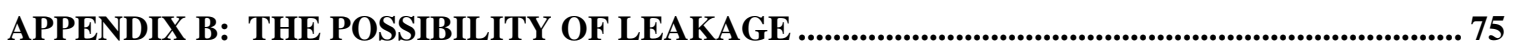

APPENDIX C: HOW UNLIKELY ARE THE ABNORMAL RETURNS? ....................................... 77 


\section{Agency Costs, Charitable Trusts, and Corporate Control: Evidence From Hershey's Kiss-Off}

\section{INTRODUCTION}

Domestic tax-exempt charitable organizations hold roughly $\$ 2$ trillion in assets. ${ }^{1}$ This impressive figure speaks to the American impulse toward philanthropy. ${ }^{2}$ But the ugly secret about charitable organizations is that their lack of a clearly defined owner invites deadweight losses arising from agency costs. True, the state attorneys general have formal authority to ensure that the managers of such organizations efficiently pursue a bona fide charitable purpose. In reality, however, the typical state attorney general is an elected political official for whom the supervision of charitable organizations has little political payoff. Accordingly, scholars tend to assume the existence of significant agency costs in charitable trusts and other charitable organizations. ${ }^{3}$

A separate agency problem arises in the context of the public corporation. Here the concern is that the interests of the company's managers will diverge from those of the shareholders. To align the incentives of managers with the interests of shareholders, the law gives shareholders various rights, including the right to sell their shares, which invites a takeover bid if the company's current management yields inferior returns. An alternative mechanism for minimizing corporate agency costs arises when the firm has a controlling shareholder or a large blockholder. ${ }^{4}$ Such a shareholder is more likely than an ordinary shareholder to have a concrete financial incentive to monitor actively and, if necessary, to impose value-maximizing operations on the company's managers. Indeed, a host of scholars and policymakers have come to embrace the utility of monitoring by blockholders, ${ }^{5}$ and the incidence of such control blocks is increasing among public U.S. firms and is even more common among public companies in Europe. ${ }^{6}$

${ }^{1}$ See http://www.irs.gov/pub/irs-soi/03eo01as.xls (providing an estimate of assets held by entities exempt from taxation under section 503(c)(3) of the Internal Revenue Code in tax year 2003).

2 Measured as a share of Gross Domestic Product, charitable giving by Americans is estimated to be "roughly three times larger than" in the second-place United Kingdom. Joel L. Fleishman, Public Trust in Not-for-Profit Organizations and the Need for Regulatory Reform 175, in Charles T. Clotfelter \& Thomas Ehrlich, eds., Philanthropy and the Nonprofit Sector in a Changing America (1999).

3 See, e.g., Richard A. Posner, Economic Analysis of Law $§ 18.5$ (7th ed. 2007); infra notes 180-191 and text accompanying.

${ }^{4}$ See, e.g., Bernard S. Black, Agents Watching Agents: The Promise of Institutional Investor Voice, 39 UCLA L. Rev. 811, 813 (1992).

5 See, e.g., Ronald J. Gilson \& Jeffrey N. Gordon, Controlling Controlling Shareholders 152 U. Pa. L. Rev. 785, 785 (2003); Jesse Eisinger, Long and Short: Hedge-Fund Activism Wins Plaudits, But the Focus Is Really on Firms' Cash, Wall St. J., Oct. 12, 2005, at C1.

${ }^{6}$ See John C. Coates IV, Ownership, Takeovers, and EU Law: How Contestable Should EU Corporations Be?, in Guido Ferrarini, et.al., ed., Reforming Company and Takeover Law in Europe 678-709, 
In 2002 the foregoing agency problems collided in a salient real world event: the attempted sale of the Hershey Company by its controlling shareholder, the Hershey Trust, a Pennsylvania charitable trust. This paper uses the 2002 Hershey incident as a natural quasi-experiment to investigate empirically: (1) the agency costs that are inherent in the charitable trust form; (2) the deficiencies of supervision of charitable entities by the state attorneys general; and (3) the comparative merits of takeovers (i.e., the market for corporate control) versus monitoring by controlling shareholders (i.e., the market for partial corporate control) in minimizing agency costs in corporate governance. ${ }^{7}$ In so doing, we make fresh contributions to the literatures of trust law and corporate law, and to the technical literature on event study methodology.

Background. The largest confectionary outfit in North America, the publiclytraded Hershey Company is the maker of such familiar goodies as Almond Joy, Jolly Ranchers, Kit Kats, Milk Duds, Reese's Pieces, Twizzlers, York Peppermint Patties, and, of course, Hershey's Chocolate Bars, Chocolate Kisses, and Chocolate Syrup. ${ }^{8}$ The Hershey Company (the "Company") is based in Hershey, Pennsylvania, a town that fancies itself "The Sweetest Place On Earth."9 In Hershey, Cocoa Avenue intersects with East Chocolate Avenue, the streetlights are shaped like Hershey's Kisses, and tourists are invited to stay in the Hotel Hershey or the Hershey Lodge while visiting local attractions such as Hershey's Chocolate World and Hersheypark.

Also based in Hershey, Pennsylvania is the Milton Hershey School for needy children (the "School"), a boarding school that enrolls, feeds, and clothes about 1,400

687 (2004) (Europe); Clifford G. Holderness, A Survey of Blockholders and Corporate Control, 2003 Econ. Pol. Rev. 51, 52-53 (2003) (United States).

${ }^{7}$ Although there is an article, a student note, and a business school case about the 2002 Hershey incident, and an article that uses the Hershey incident as one of four case studies on charity governance, none investigates empirically agency costs in the charitable trust form or addresses corporate agency costs. See Evelyn Brody, Whose Public? Parochialism and Paternalism in State Charity Law Enforcement, 79 Ind. L. J. 937, 985-99 (2004); Kenneth M. Eades et al., Hershey Foods Corporation: Bitter Times in a Sweet Place, UVA-F-1409, available at http://ssrn.com/abstract=909738; Mark Sidel, The Struggle for Hershey: Community Accountability and the Law in Modern American Philanthropy, 65 U. Pitt. L. Rev. 1 (2003); Jennifer L. Komoroski, Note, The Hershey Trust's Quest to Diversify: Redefining the State Attorney General's Role When Charitable Trusts Wish to Diversify, 45 Wm. \& Mary L. Rev. 1769 (2004). A recent biography of Milton Hershey describes the 2002 incident but offers no policy analysis. See Michael D'Antonio, Hershey: Milton S. Hershey's Extraordinary Life of Wealth, Empire, and Utopian Dreams 1-8, 242-67 (2005). In an unpublished manuscript, Harvey Dale uses the 2002 Hershey incident as one of three case studies on distortions in prudent trust investment laws applicable to charitable entities. See Harvey P. Dale, Prudence Perverted: Politics, Perceptions, and Pressures. Finally, several casebooks on trusts and estates note the Hershey incident in their treatment of charitable trusts. See Roger W. Andersen \& Ira Mark Bloom, Fundamentals of Trusts and Estates 46567 (3d ed. 2007); Lawrence W. Waggoner et al., Family Property Law: Cases and Materials on Wills, Trusts, and Future Interests 15-38 - 15-39 (4th ed. 2006).

8 See The Hershey Company, Form 10-K, Annual Report for the fiscal year ended December 31, 2006 , at $1-3$.

${ }^{9}$ See http://www.hersheypa.com/. 
students whose families have an average income of just under $\$ 14,000 .{ }^{10}$ The School's operations are funded by the Milton Hershey School Trust (the "Trust"), a Pennsylvania charitable trust worth roughly $\$ 8.8$ billion, ${ }^{11}$ more than all but the 5 largest domestic university endowments. ${ }^{12}$ The Hershey Trust Company (of Hershey, Pennsylvania) is trustee of the Trust. The School, the Trust, the Trust Company, and the Hershey Company were all founded about a century ago by Milton S. Hershey.

The fortunes of the Company, the Trust, and the School are deeply entwined. The Trust owns roughly 30 percent of the Company's shares and, thanks to a dual stock class arrangement, the Trust has over 75 percent of the votes in the Company's elections. ${ }^{13}$ The Trust's stock in the Company, which is worth over $\$ 4.7$ billion dollars, represents more than half of the Trust's $\$ 8.8$ billion corpus. Hershey dividends account for more than 40 percent of the trust's investment income. Under the terms of the Trust's governing instrument, the managers of the School are selected from the board of the Hershey Trust Company and have the power to direct the investment and disbursement policies of the Trust (hence we refer to the School's managers and the Hershey Trust Company's board collectively as the "trustees"). ${ }^{14}$

The Trust's heavy investment in the Company is not healthy for the Trust or the Company. For the Trust, not holding a diversified portfolio means that the welfare of the School and the needy children it serves is vulnerable to swings in the performance of a single Company. The Trust, in other words, is exposed to what financial economists call uncompensated risk-risk for which there is no offsetting improvement in expected return and hence could be avoided costlessly by diversifying the Trust's investment portfolio. Indeed, the modern law of trust investment has come to regard lack of diversification as close to a per se breach of fiduciary duty. ${ }^{15}$

For the Company, the Trust's controlling interest has two distorting effects. First, no matter how poorly the Company's managers run the Company, so long as

10 See http://www.mhs-pa.org/about/frequently\%2Dasked\%2Dquestions/. The $\$ 14,000$ figure is for a student for a family of three enrolling in August 2004-05. See also http://www.mhspa.org/admissions/criteria/ (stating financial eligibility limits).

${ }^{11}$ Hershey Trust summary statistics, and the sources for those statistics are collected in infra Table 1.

12 The top five are Harvard ( $\$ 25.5$ billion), Yale ( $\$ 15.2$ billion), Stanford ( $\$ 12.2$ billion), Texas ( $\$ 11.6$ billion), and Princeton ( $\$ 11.2$ billion). Number six is MIT (\$6.7 billion). See National Association of College and University Business Officers, 2005 NACUBO Endowment Study, Table 1.

13 See The Hershey Company, Form 10-K, Annual Report for the fiscal year ended December 31, 2006, at 81-84 (describing the Company's capital structure).

14 See Milton Hershey School Second Restated Deed of Trust \ף4-7, 10, 25 (Nov. 15, 1976) (“1976 Deed of Trust").

15 See Restatement (Third) of Trusts §90(b) \& cmt. g (2007); Uniform Prudent Investor Act §3 \& cmt (1994). Four "occasional exceptions" are noted in Jesse Dukeminier, Stanley M. Johanson, James Lindgren, \& Robert H. Sitkoff, Wills, Trusts, and Estates 814 (7th ed. 2005). By contrast, a 1999 Pennsylvania statute exempts the trustees of trusts in existence prior to 1999 from even a prospective duty to diversify. See Pa. Cons. Stat. tit. 20, §7204. 
the Trust maintains its controlling interest and the trustees remain listless, the Company's managers need not worry about being displaced in a takeover. Second, out of fear that taking on normal business risks might impair the welfare of the needy children who depend on a steady flow of Hershey dividends to the Trust, the Company's managers have foregone potentially lucrative business opportunities. For example, Milton Hershey's immediate successor was so worried about the needy children's exposure to volatility in the cocoa bean market through the Trust's large stake in the Company that instead of expanding the business to meet exploding consumer demand in the economic boom that followed World War II, he rationed the Company's products and ordered the construction of sixteen silos to store 64 million pounds of cocoa beans. ${ }^{16}$ Even today the Hershey Company lacks an international presence like that of competitors such as Mars, Nestlé, and Cadbury.

The Trust's concentration in the Company has also created an unfortunate expectation in the town of Hershey that the trustees will retain control over the Hershey Company indefinitely. Indeed, after the trustees abandoned an effort in 2002 to diversify the Trust's holdings by selling the Trust's controlling interest in the Company, a local lawyer who organized protests against the sale told The New York Times that "Our cash cow is safe; we're feeling really great." 17 Such sentiment, however, obscures the sad reality of the Trust's exposure to uncompensated risk and the growing disconnect between the Trust's value and its mission. Although the Trust has $\$ 8.8$ billion in assets, more than all but 5 domestic university endowments, only 1,400 children benefit from it. The quid pro quo for charitable trust status, which the common law rewards with perpetual existence and the public subsidizes through generous state and federal tax exemptions, ${ }^{18}$ is that the trust must benefit society by properly advancing a bona fide charitable purpose.

The Natural Quasi-Experiment. In recognition of the Trust's dangerous dependence on the Hershey Company, in 2002 the trustees developed the plan referenced in the prior paragraph to diversify the Trust's holdings by selling the Trust's controlling interest in the Company. The Wall Street Journal broke the news of the trustees' plan on July 25, 2002. ${ }^{19}$ The Company's stock, which is traded on the New York Stock Exchange, jumped to $\$ 78.30$ from the prior day's closing price of $\$ 62.50$, implying that the capital markets saw vast potential in the Hershey Company that had not been realized while the Company was under the control of the Trust. However, the Pennsylvania attorney general, who was then running for governor and

16 See Joel Glenn Brenner, The Emperors of Chocolate: Inside the Secret World of Hershey and Mars 198-200 (1999).

17 Francis X. Clines, Whiff of Chocolate, and the Sweet Smell of Success, N.Y. Times C3 (Sept. 19, 2002).

18 See Ilana H. Eisenstein, Keeping Charity in Charitable Trust law: The Barnes Foundation and the Case for Consideration of Public Interest in Administration of Charitable Trusts, 151 U. Pa. L. Rev. 1747, 1759-68 (2003).

19 See Shelly Branch, Sarah Ellison, \& Gordon Fairclough, Sweet Deal: Hershey Foods is Considering a Plan to Put Itself Up for Sale-Trust That Benefits a School Controls Firm, but Seeks to Diversify its Holdings-A Blow to a Company Town?, Wall St. J., July 25, 2002, at A1 (hereinafter "Branch et al., Sweet Deal"). 
whose office supervises Pennsylvania charitable trusts, brought suit to stop the sale on the grounds that it would lead to lay-offs and plant closings that would harm the central Pennsylvania community (and presumably his electoral prospects). In September 2002, after the attorney general obtained a preliminary injunction, the trustees abandoned the sale. The Company's stock dropped to $\$ 65.00$ on news of the trustees' surrender.

We use a standard event study econometric methodology to isolate price movements in Hershey's stock related to news of the sale from movements owing to ordinary market volatility. ${ }^{20}$ We find that news of the proposed sale was associated with a statistically and economically significant increase in the Company's value (in event study jargon, a "positive abnormal return") of over 25 percent. News of the sale's cancellation was associated with a statistically and economically significant decrease in the Company's value (a "negative abnormal return") of nearly 12 percent. The magnitude of these abnormal returns is astonishing; "positive abnormal returns of even 1 percent [are] considerable for competitive capital markets." ${ }^{21}$ In dollars, our findings imply that blocking the sale destroyed roughly $\$ 2.7$ billion in shareholder wealth, ${ }^{22}$ suggesting a social welfare loss owing to a suboptimal ownership structure of the Hershey Company and its underlying assets. ${ }^{23}$ Moreover, instead of improving the welfare of the needy children who are the principal objects of Milton Hershey's beneficence, the attorney general's intervention preserved charitable trust agency costs on the order of roughly $\$ 850$ million (about 15 percent of the Trust's 2002 value) and continued the Trust's exposure to uncompensated risk. ${ }^{24}$

Trust Law. Regarding trust law, this paper joins the small but growing empirical literature by providing the first quantitative empirical analysis of agency costs in the charitable trust form, ${ }^{25}$ furthering the application of agency cost analysis

20 "The event study methodology is well-accepted and extensively used in finance." Sanjai Bhagat \& Roberta Romano, Empirical Studies of Corporate Law 3, in A. Mitchell Polinsky \& Stephen Shavell, Handbook of Law and Economics (forthcoming 2007), available at http://ssrn/abstract=728103.

21 Bhagat \& Romano, supra note _, at 40-41.

22 See infra note 258.

23 The Hershey Company's announcement in early 2007 of layoffs and restructuring tends to confirm our finding of inefficiency in the Company's operations. See infra note 290 and text accompanying.

24 See infra notes 259-260.

25 There is no significant quantitative empirical literature regarding charitable trusts. With respect to private trusts, such analysis is limited to trust investment law, see Max M. Schanzenbach \& Robert H. Sitkoff, Did Reform of Prudent Trust Investment Laws Change Trust Portfolio Allocation?, 50 J.L. \& Econ. _ (forthcoming 2007) (hereinafter Schanzenbach \& Sitkoff 2007), and jurisdictional competition, see Robert H. Sitkoff \& Max M. Schanzenbach, Jurisdictional Competition for Trust Funds: An Empirical Analysis, 115 Yale L.J. 356 (2005); Max M. Schanzenbach \& Robert H. Sitkoff, Perpetuities or Taxes? Explaining the Rise of the Perpetual Trust, 27 Cardozo L. Rev. 2465 (2006). There have also been a handful of survey-based studies. See, e.g., Martin D. Begleiter, Does the Prudent Investor Need the Uniform Prudent Investor Act-An Empirical Study of Trust Investment Practices, 51 Me. L. Rev. 27 (1999). 
to charitable trusts. ${ }^{26}$ If the trustees had been managing the trust's assets efficiently, the sale announcement should not have had a very large positive effect on the value of Hershey shares not held by the Trust. Effective trustees would already have used their controlling vote block to impose a value-maximizing strategy on the Company's managers. Such efficiency-inducing efforts would have accrued to the benefit of all shareholders in the form of a higher stock price.

Yet we find that publicly-traded shares in the Company experienced a large and statistically significant positive abnormal return when news of the trustees' plan to sell broke, and a large and statistically significant negative abnormal return when the trustees abandoned the sale. Regardless of the mechanism for the increase in the Company's value on news of the sale-for example, the expectation of better management from or synergies with a prospective buyer, overpayment by an empire-building buyer, or release from the worry that aggressive management would imperil the needy children who depend on the Trust-the implication of our results is the same. The trustees not only exposed the Trust to uncompensated risk, but they also left money on the table that could have been realized for the benefit of the Trust's charitable purpose.

Our findings therefore provide the first quantitative empirical validation of prior theoretical claims of agency costs in charitable trusts and inefficient management of charitable trust assets. ${ }^{27}$ Our findings also highlight the additional but less often discussed concern that even if the attorney general does intervene in the administration of a charitable trust, such intervention might be designed to promote the attorney general's interests at the expense of the trust's charitable purpose (here on the order of roughly $\$ 850$ million). Accordingly, we provide an empirical grounding for policy analysis of new developments in the supervision of charitable entities. $^{28}$ For example, the IRS has become more active in policing charitable entities,

26 See Geoffrey A. Manne, Agency Costs and the Oversight of Charitable Organizations, 1999 Wis. L. Rev. 229; Robert H. Sitkoff, An Agency Costs Theory of Trust Law, 89 Cornell L. Rev. 621,624 (2004); Robert A. Katz, Let Charitable Directors Direct, 80 Chi.-Kent L. Rev. 689, 703-12 (2005). See also Schanzenbach \& Sitkoff 2007, supra note _, at _; Dukeminier, et al., supra note _, at 774-76; Jonathan R. Macey, Private Trusts for the Provision of Private Goods, 37 Emory L.J. 295, 315-20 (1988); A.I. Ogus, The Trust as Governance Structure, 36 U. Toronto L.J. 186 (1986); Stewart E. Sterk, Trust Protectors, Agency Costs, and Fiduciary Duty, 27 Cardozo L. Rev. 2761 (2006).

27 Although there has been no significant empirical investigation of charitable trusts, see supra note 25, there is an empirical literature on not-for-profit operating firms. For example, in John E. Core, Wayne R. Guay, \& Rodrigo S. Verdi, Agency Problems of Excess Endowment Holdings in Not-For-Profit Firms, (December 15, 2005), available at http://ssrn.com/abstract=565241, the authors find evidence of agency costs in operating not-for-profit firms that have excess endowments. Although the context and legal form is different, these results are consistent with ours. In effect, the Hershey Trust has an excess endowment, a subject we take up in infra Part IV.A in connection with the cy pres doctrine. For a survey of the literature, see Anup Malani, Tomas Philipson, \& Guy David, Theories of Firm Behavior in the Nonprofit Sector: A Synthesis and Empirical Evaluation in Edward L. Glaser, ed., The Governance of Not-For-Profit Organizations 181 (2003).

28 Although more charities take the corporate form than the trust form, see Principles of the Law of Nonprofit Organizations, Reporter's Note to $\$ 200$ (P.D. No. 4, 2007) (providing statistics), the law respecting supervision of charitable corporations derives from the law of charitable trusts. See id. $§ 200$ cmt. b; 4A Austin W. Scott \& William F. Fratcher, Trusts §348.1 (4th ed. 1989); Restatement (Second) 
almost half the states now give the donor standing concurrent with the attorney general to enforce a charitable trust, ${ }^{29}$ and the 2000 Uniform Trust Code and the 2003 Restatement (Third) of Trusts liberalize the cy pres doctrine to allow modification of a charitable trust when its total assets grow out of proportion to its purpose. ${ }^{30}$ Further, inasmuch as opponents of the sale argued that a sale would hurt the town of Hershey and the Hershey Company's workers, our findings also bear on the propriety of social investing by trustees and other fiduciaries. ${ }^{31}$ The $\$ 850$ million cost to the Trust of protecting the local "cash cow" by abandoning the sale equates roughly to a $\$ 67,000$ transfer from the Trust to each resident of Hershey, or a $\$ 62,000$ transfer to each worker at the Hershey Company. ${ }^{32}$

Corporate Law. Regarding corporate law, our findings add to the related literatures of takeovers and controlling shareholders or minority blockholders. Specifically, the aborted 2002 sale provides a natural quasi-experiment that allows us to measure the difference in the Hershey Company's value when the firm's managers were exposed to the market for corporate control in comparison to when the Company's managers were under the thumb of the trustees. We find a large, statistically and economically significant positive abnormal return on news of the Trust's probable divestment and a large, statistically and economically significant negative abnormal return when the sale was abandoned. Accordingly, the evidence indicates that the concentration of vote power in the hands of the trustees did not improve the value of the Hershey Company relative to the value of the Company in the shadow of the takeover market. As such, our findings highlight the potential inefficacy of disciplining by a controlling shareholder when that shareholder itself has distorted incentives stemming from its own internal agency problems. On this view, a hedge fund is likely to be a more effective monitor than a pension or mutual fund. ${ }^{33}$ Our findings also lend modest empirical support for the validity of the takeover model.

Financial Econometrics. Because our study is by necessity limited to a single firm, a concern might arise about the statistical power of our results. To ameliorate this concern, we undertake a host of robustness checks, several designed specifically to address the single-firm problem. In so doing, we contribute to the literature of financial econometrics by offering the first demonstration of the use of randomiza-

of Trusts $§ 348 \mathrm{cmt}$. f (1959). See also Evelyn Brody, Charity Governance: What's Trust Law Got to Do with It?, 80 Chi.-Kent. L. Rev. 641 (2005).

29 The list includes New York and California, see L.B. Research \& Educ. Found. v. UCLA Found, 29 Cal. Rptr. 3d 710 (App. 2005); Smithers v. St. Luke's-Roosevelt Hospital Center, 723 N.Y.S.2d 426 (App. Div. 2001), as well as the 19 states that have adopted Uniform Trust Code $\S 405$ (c) (2000). See http://www.utcproject.org/utc/DesktopDefault.aspx?tabindex=0\&tabid=1 (providing UTC enactment charts).

${ }^{30}$ See Uniform Trust Code $§ 413(a)$ (2000); Restatement (Third) of Trusts $\S 67$ (2003).

${ }^{31}$ See John H. Langbein \& Richard A. Posner, Social Investing and the Law of Trusts, 79 Mich. L. Rev. 72 (1980).

32 See infra note 261 . These figures jump to $\$ 214,000$ and $\$ 199,000$ if we consider the full $\$ 2.7$ billion in shareholder wealth destroyed. See infra note 291 and text accompanying.

${ }^{33}$ See Marcel Kahan \& Edward B. Rock, Hedge Funds in Corporate Governance and Corporate Control, 155 U. Pa. L. Rev. 1021 (2007). 
tion inference as a robustness check for statistical inference in a single-firm event study. ${ }^{34}$

The remainder of this paper is organized as follows. Building on the foregoing statement of background, Part I frames the inquiry with more details on Milton Hershey, the Hershey Company, and the School and Trust. Part II motivates the empirical analysis by examining the aborted sale in light of current understandings of the supervision of charitable trusts and corporate governance. In so doing, Part II situates our analysis in the existing literatures of trust law and corporate law, particularly agency cost analyses of those subjects. Part III presents our empirical analysis, which includes a graphical analysis of the data, a more formal event study analysis, and a non-technical summary of our main findings. Mindful of the need for caution in generalizing from what is in effect a case study, Part IV assesses the positive and normative implications of our findings for the ongoing policy debates in corporate law and trust law identified above. After a short conclusion, three substantive appendixes follow.

\section{MilToN HeRSHEY'S CHOCOLATE EMPIRE ${ }^{35}$}

Milton Snavely Hershey was born in 1857 in central Pennsylvania. After apprenticing in a candy store, Hershey opened stores of his own in Philadelphia, Denver, Chicago, and New York, but each failed. ${ }^{36}$ Hershey then returned home to Pennsylvania and opened a caramel business. Here Hershey's luck improved. Thanks to a large, serendipitous order from an Englishman who happened upon

\footnotetext{
${ }^{34}$ Single-firm event studies appear in the academic literature and are routine in securities litigation. See infra notes 251-252 and text accompanying.

35 More extensive treatments of Milton Hershey, the Hershey Company, and the Hershey School and Trust are readily available elsewhere. For example, D'Antonio, supra note _ , is a recent and comprehensive biography of Milton Hershey. Brenner, supra note _, is also a recent and comprehensive biography, but unlike D'Antonio, Brenner examines Hershey and the Hershey Company in juxtaposition to the Mars family and Mars Company. See also Charles Schuyler Castner, One of a Kind: Milton Snavely Hershey (1983) (fawning biography published by a local, Hershey literary guild); Nancy F. Koehn \& Erica Helms, Candy Land: The Utopian Vision of Milton Hershey (2005) (Harvard Business School case study). Mary Davidoff Houts \& Pamela Cassidy Whitenack, Images of America: Hershey (2000), is a photographic history of Milton Hershey and the Hershey entities that was sponsored by the Hershey Foundation. James D. McMahon, Jr., Built on Chocolate: The Story of the Hershey Chocolate Company (1998), is a Hershey Company-sponsored study of the Hershey Company as well as of Milton Hershey and his philanthropic legacy. McMahon is the curator of the Hershey museum. Among the older sources, Joseph Richard Snavely, a relative of Milton Hershey on Milton's mother's side, published a number of biographical works, including Milton S. Hershey: Builder (1935), The Hershey Story (1950) (hereinafter "Snavely, Story"), and An Intimate Story of Milton S. Hershey (1957). The Hershey Company published The Story of Hershey: The Chocolate Town in 1960. The Hershey Community Archives (see http://www.hersheyarchives.org/) contains a wealth of information, including unpublished books by Paul A. Wallace (a history professor at Lebanon Valley College who was hired by the school to write a Hershey biography) and Samuel Hinkle (a former president of the Hershey Company). See also Katherine Binney Shippen \& Paul A.W. Wallace, Milton S. Hershey (1959) (children's book based in part on Wallace's commissioned research).
}

\footnotetext{
${ }^{36}$ See D'Antonio, supra note _ , at 25-53.
} 
Hershey's caramel while passing through town, a bridge loan that was approved by a local loan officer against bank policy, and a better taste owing to Hershey's use of milk instead of the more common paraffin in his caramel formula, Hershey's caramel business prospered. ${ }^{37}$ The business proved so successful that in 1900 Hershey was able to sell it for $\$ 1$ million. Crucially, however, Hershey retained the Company's fledgling chocolate division. ${ }^{38}$

By all accounts, although disinterested in day-to-day business management, Hershey had "a natural flair for experimentation" and a feel for "the intimate relationship between timing, temperature and taste." 39 For Hershey, therefore, the lure of chocolate was irresistible. Chocolate - the rich, sensual, and satisfying food derived from the cocoa bean-had long been a pleasure of the upper class. ${ }^{40}$ But because chocolate was so difficult to mass produce and ship without spoiling, few others had ready access to it. Milk chocolate, a type of chocolate that would accept solid form and so could be mass produced and marketed, was thus the holy grail for confectioners. The trick was to induce the water-based milk to combine with the fatty, oil-based cocoa. ${ }^{41}$

Having earlier succeeded with milk in his caramel formula, Hershey began construction of the Hershey Chocolate Company's main factory and the surrounding town of Hershey in the heart of Pennsylvania's dairy country even before perfecting a viable milk chocolate recipe. ${ }^{42}$ The timing was tight, but after much experimentation Hershey eventually solved the problem of combining milk and cocoa. Hershey's solution, which was to boil the milk to the brink of souring, explains the hallmark bitter, harsh taste of Hershey's milk chocolate. ${ }^{43}$ Although panned by chocolate connoisseurs, who preferred the more subtle flavors of Cadbury, Lindt, and Nestlé, Hershey's grittier chocolate was the first encounter with the substance for many Americans. Hershey's chocolate thus came "to define the taste of chocolate for" the American palate ${ }^{44}$ - a process helped along by Hershey's production of "Field Ration D" during World War II, a high-calorie, high-melting point chocolate bar developed for the Army that garnered the Hershey Company an exemption from wartime rationing, ${ }^{45}$ and by fawning press coverage of the corporate "utopia" that was the town of Hershey. ${ }^{46}$

\footnotetext{
37 See Brenner, supra note _, at 74-80, 88; D'Antonio, supra note _, at 54-58.

38 See Brenner, supra note _, at 88; D'Antonio, supra note _, at 89-91.

39 Brenner, supra note _, at 77. See id. at 73, 83; D’Antonio, supra note _, at 29, 58.

40 See Brenner, supra note_, at 91-102.

41 See id., at 91-92.

42 See id., at 89-90, 102; D'Antionio, supra note _, at 101-06.

43 See Brenner, supra note _, at 103-13. See also D'Antonio, supra note _, at 95-108.

44 D’Antonio, supra note _, at 108; Brenner, supra note _, at 63, 109-111.

45 See Brenner, supra note _, at 8-11, 153.

46 See id., at 131-32; D'Antonio, supra note _, at 177-79.
} 
As with the caramel business, Hershey left the day-to-day operations of the chocolate company to others and turned his attention elsewhere, particularly to sponsorship of the Hershey School. ${ }^{47}$ Indeed, because Milton and his wife Catherine never had children of their own, the orphan boys enrolled in the Hershey School became their surrogate children. "This was especially true for Milton, who reviewed every application and helped to choose the youngsters who got rooms at the homestead." 48 Milton later explained: "Well, I have no heirs; so I decided to make the orphan boys of the United States my heirs." 49

The original 1909 Deed of Trust that created the School was quite detailed. The School-then known as the Milton Hershey Industrial School-was to "be permanently located in Derry Township," the political subdivision of Pennsylvania in which the town of Hershey is situated, on farm land conveyed to the Trust by the Milton Hershey. ${ }^{50}$ The trust instrument prohibited the use of Trust funds for any other purpose. ${ }^{51}$ The School was to admit "poor, healthy, white male orphans" between the ages of four and eight. The term "orphan" was defined to mean "a child whose father is deceased." 52 Preference was given to "orphans" from the three counties closest to the town of Hershey, then from the rest of Pennsylvania, and then the rest of the United States. ${ }^{53}$ According to a family biography, the School was limited to boys because Milton Hershey was of the view that girls were "useful in the home" and hence more likely to be adopted. ${ }^{54}$ Needy boys, by contrast, were thought vulnerable to becoming "shiftless and criminal men who would spawn another generation of undesirables." 55

The Hersheys instructed that "the main object in view is to train young men to useful trades and occupations, so that they can earn their own livelihood. Each and every scholar shall be required to learn, and to be thoroughly instructed in some occupation or mechanical trade, so that when he leaves the School . . he may be able to support himself." 56 Once admitted, an orphan could stay at the school until the age of eighteen. Orphans who went on to college were eligible for tuition assis-

\footnotetext{
47 See Brenner, supra note _, at 131-33, 137-38; D'Antonio, supra note _, at 169.

48 D'Antonio, supra note _, at 128.

49 Brenner, supra note _, at 117.

${ }^{50}$ Milton Hershey School Deed of Trust $\mid 11$ (November 15, 1909) (hereinafter "1909 Deed of Trust").

${ }^{51}$ Id. at $₫ 8$.

52 Id. at $₫ 13$

53 Id. at $\uparrow 14$.

54 Snavely, Story, supra note _, at 126.

55 D'Antonio, supra note _, at 129.

561909 Deed of Trust, supra note _, at $\$ 17$.
} 
tance. ${ }^{57}$ Orphans who did not plan on further education were given a $\$ 100$ grant, new clothes, and help finding a job. ${ }^{58}$

The School was also to feed, clothe, and board the orphans. "All orphans admitted to the School shall be fed with plain, wholesome food; plainly, neatly, and comfortably clothed, without distinctive dress, and fitly lodged."59 Provision of room and board was and still is implemented by placing the students in a home with several other students supervised by a married couple who serve as house-parents. ${ }^{60}$

In 1918, three years after Catherine died, Milton Hershey transferred substantially all of his assets-including his stock in the Hershey Company, then worth $\$ 60$ million-to the Trust. ${ }^{61}$ The transfer wasn't publicly disclosed until The New York Times ran a story about it three years later. ${ }^{62}$ But once the School's dependence on the Company was known, the Company's managers took notice, becoming cautious to ensure a steady flow of dividends to the Trust. ${ }^{63}$

Eventually, after falling behind the Mars Company in the 1970s, the Hershey Company was forced to embrace modernity. ${ }^{64}$ The Company's recent chief executives speak of being "more conscious of our stock price and what we have to do to improve the stock price, to give value to our shareholders."65 Thanks to better management, improved marketing, and several successful acquisitions, the Company is again number one in the North American confectionary market. ${ }^{66}$ In 2006, the Company reported net sales of $\$ 5$ billion and at year end had a market capitalization of $\$ 11.5$ billion. ${ }^{67}$ The Mars Company remains a close second, however, and in 2007 the Company announced a plan to streamline operations that will include domestic plant closings and layoffs and the construction of a new factory in Mexico. ${ }^{68}$

Just as the Company has modernized, so has the Trust and the School. Since 1909, the original Deed of Trust has been modified to expand the age range for admission to 4 through 14 (1933) and then to 4 through 16 (1970); to redefine "orphan" to include children whose mothers are deceased (1933) and then to replace "orphan"

57 See id. at $\$ 21$.

58 See Brenner, supra note _ , at 132-33.

591909 Deed of Trust, supra note _, at $\$ 17$.

60 See http://www.mhs-pa.org/student\%2Dlife/life\%2Din\%2Dthe\%2Dstudent\%2Dhome/.

61 See Brenner, supra note _, at 134-35; D’Antonio, supra note _, at 169.

62 See M.S. Hershey Gives \$60,000,000 Trust For an Orphanage, N.Y. Times A1 (Nov. 9, 1923).

63 See Brenner, supra note _, at 136-37, 230, 260-61; D’Antonio, supra note _, at 245.

64 See D'Antonio, supra note _, at 244-46; Brenner, supra note _, at 259-78, 300-01.

65 Brenner, supra note _, at 317-18.

66 See supra note 8.

67 The Hershey Company, Form 10-K, Annual Report for the fiscal year ended December 31, 2006, at $12,19,81$.

68 See infra note 290 and text accompanying. 
with "children" who do not receive "adequate care from one of his or her natural parents" (1976); to drop the word "Industrial" from the School's name (1951); and, as is now typical in discriminatory trusts, to remove the racial (1970) and gender limitations (1976). ${ }^{69}$

Meanwhile the School, which in the 1980s was called "terrible" by accrediting officials, has evolved from an agrarian vocational institution to more of a college preparatory school. 70 Today the School sits on 2,640 "pristine acres of rolling countryside" and boasts state-of-the-art facilities (including the second largest marble rotunda in the country). ${ }^{71}$ The School clothes, feeds, and provides health care for 1,400 students whose average family income is under $\$ 14,000 .{ }^{72}$ The School also gives scholarships for college tuition. All of the School's operations are funded by the $\$ 8.8$ billion Hershey Trust. Table 1 summarizes the Trust's financial position and dependence on the Hershey Company.

69 See In re Petition of the Hershey Industrial School for Modification of Trust (Oct. 30, 1933); In re Petition of the Hershey Industrial School for Modification of Trust (Dec. 17, 1951); Milton Hershey School Restated Deed of Trust $\$ 13$ (Dec. 24, 1970); 1976 Deed of Trust $₫ 13$. On modification of discriminatory trusts, see Dukeminier et al., supra note at $742-43$.

70 See D'Antonio, supra note _, at 250-54. This is not to say, however, that the evolution was smooth. On the contrary, the School's alumni association accused the School's managers of conflicts of interest and other misdeeds, see Kirkpatrick \& Lockhart, LLP, Findings and Conclusions of the Special Counsel (Sept. 1, 2000); Milton Hershey School Alumni Association, Bias, Flaw, \& Avoidance: A Response to the K\&L Report (Oct. 16, 2000), and some of the association's complaints led to an investigation by the state attorney general. See D'Antonio, supra note _, at 265-66; infra note 101. The trustees' dealings with the attorney general over the association's complaints played a role in prompting the trustees' interest in diversifying. See infra note 81 and text accompanying.

\footnotetext{
${ }^{71}$ Brenner, supra note _, at 135. See also D'Antonio, supra note _, at 244.

72 See supra note 10 and text accompanying.
} 
Table 1:

Hershey Trust Summary Statistics

\begin{tabular}{|c|c|c|c|c|c|c|}
\hline & 2000 & 2001 & 2002 & 2003 & 2004 & 2005 \\
\hline \multicolumn{7}{|c|}{ Trust Corpus } \\
\hline Total & $\$ 4,593,255,021$ & $\$ 5,151,587,064$ & $\$ 5,816,887,358$ & $\$ 5,851,334,397$ & $\$ 7,095,503,724$ & $\$ 8,752,608,388$ \\
\hline From HSY & $\$ 1,969,448,811$ & $\$ 2,570,290,384$ & $\$ 3,341,036,837$ & $\$ 3,100,444,712$ & $\$ 3,578,929,577$ & $\$ 4,718,956,071$ \\
\hline Percent & & & & & & \\
\hline From HSY & $43 \%$ & $50 \%$ & $57 \%$ & $53 \%$ & $50 \%$ & $54 \%$ \\
\hline \multicolumn{7}{|c|}{ Trust Investment Income (i.e., Interest and Dividends From Securities) } \\
\hline Total & $\$ 118,099,233$ & $\$ 122,229,432$ & $\$ 118,569,196$ & $\$ 123,411,502$ & $\$ 130,661,524$ & $\$ 139,632,178$ \\
\hline From HSY & $\$ 41,255,383$ & $\$ 44,358,938$ & $\$ 47,888,318$ & $\$ 51,843,526$ & $\$ 62,734,729$ & $\$ 60,168,752$ \\
\hline $\begin{array}{l}\text { Percent } \\
\text { from HSY }\end{array}$ & $35 \%$ & $36 \%$ & $40 \%$ & $42 \%$ & $48 \%$ & $43 \%$ \\
\hline \multicolumn{7}{|c|}{ Trust Ownership of and Voting Rights in Hershey Company ${ }^{13}$} \\
\hline $\begin{array}{l}\text { Percent } \\
\text { Owned }\end{array}$ & $32 \%$ & $32 \%$ & $32 \%$ & $33 \%$ & $30 \%$ & $31 \%$ \\
\hline $\begin{array}{l}\text { Percent } \\
\text { of Votes }\end{array}$ & $77 \%$ & $77 \%$ & $77 \%$ & $78 \%$ & $78 \%$ & $79 \%$ \\
\hline
\end{tabular}

The size of the Hershey Trust's corpus is striking, particularly given the School's small size. In spite of the Trust's mushrooming corpus, the School "served no more children at the start of 2005 than it did in 1963."74

The Trust's endowment is also remarkable for its breathtaking lack of diversification. Of the Trust's $\$ 8.8$ billion corpus, $\$ 4.7$ billion (54 percent) is in Hershey Company stock (representing 31 percent of all outstanding shares), ${ }^{75}$ and close to half of the Trust's income from interest and dividends comes from the Hershey Company. These figures, moreover, understate the Trust's diversification problem because the Trust's other assets include a substantial stake in the Hershey Entertainment Company and real estate holdings in the town of Hershey.

The problem with an undiversified portfolio is that it entails uncompensated risk-risk for which there is no offsetting improvement in expected return and hence could be avoided costlessly by diversifying. ${ }^{76}$ To understand why, suppose ten com-

73 The figures for the Trust's ownership of and voting rights in the Company are slightly overstated in that they include other shares held by the Hershey Trust Company for some estates and trusts other than the Hershey Trust. See, e.g., The Hershey Company, Form 10-K, Annual Report for the fiscal year ended December 31, 2004, at 66. The Trust has a disproportionate voting share to its ownership share on account of the Company's dual class stock structure. See supra note 13.

${ }^{74}$ D'Antonio, supra note _, at 266.

75 If the Hershey Trust were a foundation, it would trigger the excess business holding provision in I.R.C. §4943. See Marion Fremont-Smith, Governing Nonprofit Organizations: Federal and State Law and Regulation 276-78 (2004).

76 For a more in-depth treatment of the perils of not diversifying that is directed toward trust portfolio management, see John H. Langbein, The Uniform Prudent Investor Act and the Future of Trust 
panies, each in a different industry and each with different managers. If all ten have the same expected risk and return profile, then a portfolio comprising all ten stocks would have the same expected return as a portfolio of just one. But there will be less variance in the actual return of the ten-stock portfolio than in the portfolio of one, because in the larger portfolio losers will be offset by winners. ${ }^{77}$ Thus the single-stock portfolio presents more risk-more volatility-without an offsetting increase in expected return.

To be sure, general market risk (in the jargon of financial economics, "systematic risk") cannot be diversified away. But most firm risk ("unsystematic risk") can be avoided. The key to the risk-avoiding magic of diversification, which can be achieved with as few as twenty stocks, ${ }^{78}$ is that unsystematic risk is often inversely correlated across firms. A breakthrough in solar power, for example, would negatively affect an oil company, but would positively affect an energy-dependent manufacturing concern. In the case of the Hershey Company, and so the Hershey Trust, firm-specific risk factors include volatility in the cocoa and sugar markets. ${ }^{79}$

According to published accounts, after the technology bubble burst and the Enron and Worldcom scandals, the trustees became increasingly worried about holding such an undiversified portfolio. ${ }^{80}$ Those worries were exacerbated after meetings in December 2001 with the Pennsylvania attorney general's office in which the trustees reportedly were urged to diversify. ${ }^{81}$

Nothing in the Deed of Trust requires retention of the Trust's stock in the Hershey Company. On the contrary, the trust instrument gives the trustees "full power and authority" over the Trust's portfolio management. ${ }^{82}$ As a matter of hornbook law, therefore, the trustees have the authority to diversify the Trust's invest-

Investing, 81 Iowa L. Rev. 641, 647-48 (1996). Although there is some literature that suggests that occasionally investors can increase their return with a concentrated portfolio, see, e.g., Azriel Levy \& Miles Livingston, The Gaines From Diversification Reconsidered: Transaction Costs and Superior Infomration, 4 Fin. Markets Inst. \& Instr. 1 (1995), that notion does not bear on analysis of the Hershey Trust. The trustees did not claim any benefits from holding the concentration. On the contrary, as we detail in Part II.A, the trustees wanted to diversify.

77 Assuming returns in the ten firms are independent, the ten-firm portfolio would have 1/10 the variance of a one-firm portfolio.

78 In the words of the leading finance text, "once you have a portfolio of 20 or more stocks, diversification has done the bulk of its work. For a reasonably well-diversified portfolio, only market risk matters." Richard A. Brealy \& Stewart C. Myers, Principles of Corporate Finance 168 (7th ed. 2003). See also Jonathan R. Macey, An Introduction to Modern Financial Theory 22-27 (2d ed. 1998).

${ }^{79}$ For examples of wild swings in these commodities and the effects of those swings on the Hershey Company, see Brenner, supra note _, at 137, 199, 231-42.

80 See Branch et al., Sweet Deal, supra note 19

81 See id.; Robert Frank \& Sarah Ellison, Meltdown in Chocolatetown-Controlling Trust at Hershey Bows to Opposition to Sale; Company Faces Future Alone, Wall St. J. B1 (Sept. 19, 2002) (hereinafter "Frank \& Ellison, Meltdown in Chocolatetown"); Sarah Ellison, Sale of Hershey Foods Runs Into Opposition-In a Company Town, Locals And State Official Have Trust Members Wavering, Wall St. J. A3 (Aug. 26, 2002).

821976 Deed of Trust 95 . 
ment portfolio if they determine that diversifying is in the best interests of the Trust. 83

\section{Agency Costs And The Aborted 2002 SAle}

\section{A. The Aborted Sale ${ }^{84}$}

News of the trustees' plan to sell the Trust's controlling interest in the Hershey Company was first made public on Thursday, July 25, 2002, by a front-page story with a two-column headline in the Wall Street Journal. ${ }^{85}$ Both the Trust and the Company confirmed the Journal's story that day. The subsequent media coverage, which credited the Journal with breaking the story, reported that securities analysts were surprised by the announcement. ${ }^{86}$ In the ensuing litigation, the trustees and the attorney general likewise credited the Wall Street Journal with making the sale plan public. ${ }^{87}$

83 See illustration 1 to Principles of the Law of Nonprofit Organizations $§ 310$ (T.D. No. 1, 2007), which is based on the Hershey Trust:

The investment assets of the $\mathrm{H}$ School consist primarily of a controlling interest in $\mathrm{H}$ Foods Corporation worth over $\$ 5$ billion. $\mathrm{H}$ foods is a major employer in the town of $\mathrm{H}$. The shares had been contributed by the donor upon his founding of the H School, but the donor did not limit the ability of the H School governing board to dispose of this investment in the company he had also founded. The members of the H School governing board determined that it would be prudent for the charity to diversify its investments, and therefore to dispose of the stock in H Foods, and that not to do so would entail substantial financial risk that would far outweigh the benefit of the community goodwill. Because the school does not have as a charitable purpose maintaining a controlling interest in H Foods for the benefit of the town of $\mathrm{H}$, the governing board may prudently diversify.

${ }^{84}$ Our narrative of the aborted sale is presented in day-by-day detail to allow the reader to evaluate our choices of event dates in the subsequent empirical analysis. To ensure that we did not miss important events, we examined every story in the Wall Street Journal, New York Times, and Pittsburgh Post-Gazette that mentioned "Hershey" between June 25, 2002, and October 18, 2002. We also examined the Hershey Company's principal 2002 SEC filings.

85 See Branch et al., Sweet Deal, supra note 19.

86 See, e.g., Greg Winter, Hershey Is Put on the Auction Block, N.Y. Times C5 (July 26, 2002); Theresa Howard, Hershey Soars on Possibility of Sale of Controlling Stake, USA Today 3B (July 26, 2002); Martha Raffaele, Hershey, Trust Discuss Possible Sale, Pittsburgh Post-Gazette W1 (July 26, 2002). See also D'Antonio, supra note _, at 257 (noting that "the public remained in the dark" until the July 25 Journal story).

87 See Brief for Appellee, Opposing Appellants' Application for Suspension of Injunction Pending Appeal, In Re: Milton Hershey School Trust, No. 2111 C.D. 2002, at 7 (hereinafter "Brief of Appellee") (citing a stipulation of the parties).

The only possible exception the otherwise uniform view that news of the sale broke on July 25 is a cryptic reference in the original July 25 Wall Street Journal story to "rumblings in the food industry six to eight months ago that the trust was looking to diversify its assets and had hired an investment bank to advise it on a possible sale." Branch, Sweet Deal, supra note 19. These "rumblings," however, do not appear to have lessened the surprise of the July 25 story. Further, if these rumblings did affect the price of Hershey Company stock prior to July 25, such an effect would be positive and hence would work against our finding of a large, positive abnormal return on July 25. We take up the possibility of leakage in infra Appendix B. 
According to the July 25 Journal story, the trustees were "keen to diversify" the Trust's portfolio and had rejected alternatives to a sale "such as a buyback or major recapitalization" in which the Company would buy some of the Trust's shares at a premium. ${ }^{88}$ The Journal also reported that "People familiar with the matter say that Pennsylvania Attorney General Mike Fisher's office, while not advocating a sale of the company, has urged the Hershey trust to diversify." 89 The Journal story predicted a "grim" reception for the trustees' plan among Hershey residents and the Company's workers. ${ }^{90}$

Hershey residents and workers received the news grimly indeed. With "tears in his eyes" the Hershey Company CEO Richard Lenny recorded a statement to employees, which was broadcast on the web every half hour, to the effect that the sale "was not his doing" and that he had offered the Trust alternative means to diversify. ${ }^{91}$ The next day, Friday, July 26, a local newspaper reported that "Hershey residents questioned why the trust would need to sell Hershey Foods, wondered how the sale would affect the village, and asked if a sale would be consistent with Milton Hershey's vision of social responsibility." ${ }^{2}$ The chairman of the local Township's Board of Supervisors warned that "[t]he economics of the region could be impacted severely" from loss of jobs and tax base. ${ }^{93}$ "This could be tumultuous," he said. ${ }^{94}$ On Sunday, July 28, a local paper quoted the president of the School's alumni association, which had previously accused the trustees of conflicts of interest and other forms of malfeasance, ${ }^{95}$ as saying that the trustees' plan was "despicable." 96

Investors took a more favorable view. On Thursday, July 25, the day of the Wall Street Journal's first story, the Hershey Company's common stock (ticker symbol HSY) closed at $\$ 78.30$, up $\$ 15.80$ (more than 25 percent) from the prior day's closing price of $\$ 62.50$. A little over 19 million HSY shares traded on July 25, about ten times as many as the day before. ${ }^{97}$ On Friday, July 26, the press ran stories

88 Branch, Sweet Deal, supra note 19.

89 Id. See also supra note 81 and text accompanying.

90 Branch, Sweet Deal, supra note 19.

91 Greg Winter, Hershey is Put on the Auction Block, N.Y. Times C5 (July 26, 2002); Shelly Branch \& Sarah Ellison, Wall St. J. B1 (July 26, 2002).

92 Dan Shope \& Keith Herbet, The Morning Call, Hershey Wants to Swap Candy for Dough; School Trust Could Get $\$ 15$ Billion for the Chocolate Giant, Morning Call A1 (July 26, 2002).

93 Winter, supra note _.

94 Shope \& Herbet, supra note _.

95 See supra note 70; infra note 101. Ironically, the resulting investigation by the attorney general helped prompt the trustee's interest in diversifying. See supra note 81 and text accompanying.

96 Judy A. Strausbaugh, Hershey Sale May Force Town to Kiss Life Good0Bye; Many Mourn, Speculate What Could Change in Chocolatetown USA, Lancaster Newspaper D1 (July 28, 2002). The alumni association had opposed previous actions by the trustees and had made complaints with the state attorney general over alleged self-dealing and other improprieties. Id.

97 We detail the sources for our stock price data in infra Part III.A. We obtained trading volume data from the Hershey Company's webpage. See http://www.thehersheycompany.com/ir/pricelookup.asp\#. 
with speculation on potential buyers and possible prices. ${ }^{98}$ HSY closed at $\$ 78.72$ on Friday, July 26. On Monday, July 29, HSY closed at $\$ 79.49$.

By Monday, July 29, local opposition to the sale began to organize. The School's alumni association asked D. Michael Fisher, the Pennsylvania attorney general and Republican candidate for governor in the following November gubernatorial election, "to remove the trust's leadership for 'fiscal waste and child-care incompetence."'99 On Wednesday, July 31, six former trustees (including the former Hershey Company CEO Richard Zimmerman) made public statements in opposition to the sale. ${ }^{100}$ Both Fisher and Ed Rendell, the democratic gubernatorial candidate who ultimately won, came out in opposition to the sale. ${ }^{101}$

As part of a grass-roots "Derail The Sale" campaign, a public rally against the sale was held on Friday, August 2.102 Residents began displaying yard signs with slogans such as “The Hershey Trust-An Oxymoron” and "Don't Shut Down Chocolate Town."103 John Dunn, a former Hershey marketing executive, crafted the opposition's message to ensure favorable media coverage. ${ }^{104}$ By Monday, August 5, the editorial page of the Lancaster New Era opined that "[i]t almost seems that the current members of the trust are about the only people to think the sale is a good idea." 105 HSY closed at $\$ 72.37$ on Monday, August 5, down $\$ 7.12$ (about 9 percent) from the post-sale announcement high of $\$ 79.49$ on Monday, July 29.

98 See, e.g., Gordon Fairclough \& Erin White, Shake-Up in Candyland-Sale of Chiclets, Dentyne, And Nestle's Hold on KitKat, Make Hershey Bidding Sticky, Wall St. J. B1 (July 26, 2002); Neil Buckley, William Hall, \& Julia Ratner, Nestle and Kraft Head Race to Buy Hershey, Fin. Times 1 (July 26, 2002); Ameet Sachdev, Hershey May Lure Kraft and Nestle; Bidding War Likely to Mean Sweet Deal, Chi. Trib. N1 (July 26, 2002). The stories continued thereafter. See, e.g., Neil Buckley, Jeremy Grant, \& Juliana Ratner, Candy's Dandy But Strategy Remains the Key, Fin. Times 24 (Aug. 2, 2002); Elizabeth Olson, Nestle Strikes \$2.6 Billion Deal to Buy Chef America, N.Y. Times W1 (Aug. 7, 2002). 2002).

99 Shelly Branch, Sale of Hershey to be Contested by School Alumni, Wall. St. J. B10 (July 29,

100 Shelly Branch, Trust Pushing Sale of Hershey Faces Rising Level of Criticism, Wall St. J. B6 (Aug. 1, 2002) (hereinafter "Branch, Criticism").

101 See id.; Trust Should Not Sell Hershey Foods, Lancaster New Era A6 (August 5, 2002) (hereinafter "Lancaster, Not Sell"). At the same time that Fisher announced his opposition to the sale, he also announced an agreement with the trustees over the alumni association's prior accusations of conflict of interest and other such charges. See supra note 70; Branch, "Trust Pushing," supra note __ Peter Jackson, Hershey School Agrees to Rule Changes, Pittsburgh Post-Gazette B8 (Aug. 1, 2002).

102 See Ron Insana, Hershey Foods' Board of Trustees Thinking of Selling the Company has Many Upset, CNBC News Transcripts (Aug. 2, 2002); Branch, Criticism, supra note _; Martha Raffaele, Joy in Candyland, Pittsburgh Post-Gazette E1 (Sept. 19, 2002).

103 D'Antonio, supra note _ at 260.

104 Id. at 259-60.

105 See Lancaster, Not Sell, supra note _. See also Stacey Hirsh, Hershey Residents Fear Worst if Company is Sold, Pittsburgh Post-Gazette E8 (Aug. 8, 2002); Thomas Hylton, Honor Hershey, Pittsburgh Post Gazette B1 (Aug. 11, 2002) 
On Tuesday, August 6, Fisher met with several of the trustees to urge them to reconsider their sale plan in favor of alternative modes of diversification. ${ }^{106} \mathrm{On}$ Wednesday, August 7, the trustees held a special day-long meeting to consider Fisher's proposals and the merits of continuing the sale. That evening, after the stock market closed, the trustees issued a release stating that they would continue to pursue the sale because they believed that the sale "is in keeping with [their] fiduciary responsibility to protect and preserve the trust." 107 In the next day's trading (Thursday, August 8) HSY closed at $\$ 74.09$, up $\$ 2.20$ (3 percent) from the prior day's closing price of $\$ 71.89$.

Fisher then announced that he would turn to the courts. 108 On Monday, August 12, Fisher asked the local court with jurisdiction over the Hershey Trustknown in Pennsylvania as the Orphans' Court—to issue an order to the trustees to show cause why any sale of the Company should not be subject to judicial approval. The court issued the order to show cause the following Monday, August 19. ${ }^{109}$ Said a spokesman for Fisher, "Ultimately, we hope that the court will require that any offer for Hershey Foods be revealed to our office and the court and that any proposed sale be subject to court approval." 110 HSY closed at $\$ 74.56$ on August 12 and $\$ 74.71$ on August 19.

Later that week, on Friday, August 23, Fisher petitioned for a preliminary injunction to bar any sale pending the court's resolution of the propriety of the trustees' sale plan. HSY closed at $\$ 75.03$. Fisher's office also announced that it was drafting legislation that would require trustees to consider the effect on the community in making investment decisions. 111 The trustees filed their papers in opposition to the injunction request on the following Monday, August 26. HSY closed at $\$ 76.80$. The Orphans' Court deferred ruling on the injunction request, scheduling a hearing for Tuesday, September 3.

106 See Sarah Ellison, Hershey Trust Board Decides to Continue with Sale Option, Wall St. J. B6 (Aug. 8, 2002) (hereinafter "Ellison, Decides to Continue"); Company News: Hershey Trust Affirms Intention to Sell Candy Maker, N.Y. Times 3 (Aug. 8, 2002) (hereinafter "Affirms Intention to Sell"). See also Courtney Schlisserman, Fisher Urges Hershey Trust Not to Sell, Pittsburgh Post-Gazette E8 (August 8,2002$)$.

107 Ellison, Decides to Continue, supra note _ ; Affirms Intention to Sell, supra note _.

108 See Company News: Attorney General Says Court Must Decide Hershey Sale, N.Y. Times C1 (Aug. 10, 2002).

109 See In re Milton Hershey School Trust, 807 A.2d 324, 328 (Pa. Comm. Ct. 2002) (reproducing the Orphans' Court's opinion of Sept. 10, 2002); See Brief for Appellants The Hershey Trust Company and the Milton Hershey School in Support of Their Application for Suspension of Injunction Pending Appeal, In Re: Milton Hershey School Trust, No. 2111 C.D. 2002, at 12-13 (hereinafter "Brief of Appellant”); Brief for Appellee, Opposing Appellants' Application for Suspension of Injunction Pending Appeal, In Re: Milton Hershey School Trust, No. 2111 C.D. 2002, at 5-6 (hereinafter "Brief of Appellee").

110 See Marc Levy, Court Orders Hershey Trust to Defend Sale, Pittsburgh Post-Gazette E2 (Aug. 20, 2002).

111 See Company News: Delay is Sought in Effort to Sell Hershey Food, N.Y. Times C1 (Aug. 24, 2002); Marc Levy, Hershey Sale Tough, Not Impossible, Lancaster News D1 (Aug. 25, 2002). The proposed legislation was later enacted. See discussion infra 
At the September 3 hearing, with protestors outside the courthouse "carrying signs and singing a Hershey's chocolate jungle,"112 the main witness for the attorney general was former Hershey CEO Richard Zimmerman. Zimmerman predicted that an acquiring company would seek to cut costs first by eliminating jobs made redundant by the merger and second by shutting down less efficient manufacturing plants. "And I suspect," testified Zimmerman, "that one would start with the [main Hershey] plant that's nearly a hundred years old."113 In Zimmerman's view, although these actions might improve the profitability of the combined company, "there are very many more things in life more important than money."114

The trustees argued that the trust instrument authorized them to divest the Trust's holdings in the Company and that prudent investment practice required diversification. Indeed, the trustees' investment advisor testified that the trust's heavy investment in the Company made its portfolio "twice as risky as the typical college or university or independent school" portfolio. ${ }^{115}$ The investment advisor also admitted, however, that the Trust had never failed to produce enough income for the school in spite of its concentration in Hershey. ${ }^{116}$

The next day, Wednesday, September 4, the trial judge issued the preliminary injunction with an opinion to follow. ${ }^{117}$ Both the timing and the result of the judge's decision appear to have been a surprise. The Wall Street Journal's Wednesday story about the Tuesday hearing quoted the judge as having said that he would rule by "week's end" and reported that "[m]any legal observers said that the judge appeared unlikely to issue an injunction."118 In heavy trading (10 million shares, more than 4 times the prior day's trading volume), HSY closed on Wednesday at $\$ 72.51$, down $\$ 3.09$ (4 percent) from Tuesday's closing price of $\$ 75.60$.

On Thursday, September 5, the trustees appealed and the appellate court scheduled a hearing for Wednesday, September 11.119 In their Thursday coverage of

112 D'Antonio, supra note _, at 263. On Monday, September 2 (Labor Day), the day before the hearing, a local paper ran a story about Milton Hershey's "dream of building a "model town" and the reliance of the community on the Company, which "is considered a good corporate citizen and has an estimated annual budget of several million for charities." Hershey: Candy is Just the Beginning, Intelligencer Journal B2 (Sept. 2, 2002). See also Andrew Ross Sorkin, Market Place: Price Tag and Local Politics Damp Interest in Hershey, N.Y. Times C1 (Aug. 27, 2002).

113 Brief for Appellee, supra note _, at 9-10.

114 Brief for Appellee, supra note _, at 11.

115 Brief for Appellant, supra note _, at 15.

116807 A.2d at 332-33.

117807 A.2d at 328.

118 Sarah Ellison and Christina Cheddar, Decision on Hershey Injunction Is Expected by End of the End of the Week, Wall St. J. B4 (Sept. 4, 2002). After the hearing Fisher also told reporters that he expected a ruling later in the week. Pennsylvania Tries to Block Sale of Hershey, N.Y. Times C4 (Sept. 4, 2002).

119 See Appeals Court to Hear, Wall St. J. B6 (Sept. 6, 2002); Hershey’s Owners Seek Lifting of Injunction, N.Y. Times C5 (Sept. 6, 2002). 
the trial court's Wednesday ruling, both the Wall Street Journal and the New York Times reported that "legal experts" predicted that the trial court would be reversed on appeal. ${ }^{120}$ HSY closed at $\$ 74.30$ on Thursday, up $\$ 1.79$ (about 2.5 percent) from Wednesday's closing price. Meanwhile, Fisher praised the trial court's ruling, saying that the injunction would allow him "to represent the public's interest" and would allow "the court to determine how a sale could hurt this community." 121 On Friday, September 6, HSY closed at $\$ 73.85$.

On Monday, September 9, the parties filed their appellate briefs; ${ }^{122} \mathrm{HSY}$ closed at $\$ 73.53$. The attorney general conceded that the trust was imprudently undiversified "and that it would be "desirable' for the Trust to diversify its holdings," but he also argued that "there was no testimony that it needs to do so immediately, within the next few days or weeks." 123 By contrast, "the current employees of Hershey Foods would be worse off under an acquisition than they are now," and the sale of the Company "would seriously impair, if not destroy, the symbiotic relationship which has existed for many decades among the company, the School and its Trust, and the other institutions which together carry on Milton Hershey's unique vision." Hence, the attorney general argued that the balance of equities favored upholding the preliminary injunction. "At is core," the attorney general explained, "this case raises the question of whether the administrators of a charitable trust can operate the trust to inflict injury and harm upon the public at large, which is the ultimate beneficiary and real party in interest of all charitable trusts." 124

In response, trustees argued that 'the public' benefit is not the personal economic of social benefit that 'the public' derives from the assets that the charitable trust holds-rather, 'the public' benefits from the achievement of the specific charitable purpose for which the trust is established."125 Moreover, nothing in the Deed of Trust indicated that Milton and Catherine Hershey wanted the Trust to maintain its ownership of the Hershey Company, or to maintain the economic health of the local community, or to provide job security for the Company's employees. On the contrary, the only interest named in the Deed of Trust was the Milton Hershey

120 See Andrew Ross Sorkin, Court Ties Up Hershey Deal, For Time Being, N.Y. Times C1 (Sept. 5, 2002) (stating that "most legal experts suggested that the injunction would be overturned"); Sarah Ellison, Hershey Sale is Temporarily Blocked, Wall St. J. A3 (Sept. 5, 2002) (stating that "legal experts believe that the attorney general's arguments might not hold up on appeal"). USA Today quoted a Philadelphia lawyer "who filed a lengthy brief against the sale" as saying "[l]egally, it's hard to say the trust doesn't have the discretion to sell." Gary Strauss \& Thor Valdmanis, Judge Halts Hershey Sale; Shares Dive 4\%, USA Today 1B (Sept. 5, 2002).

${ }^{121}$ Hershey Sale Blocked Temporarily by Judge, Chi. Trib. 3 (Sept. 5, 2002); Sorkin, Ties Up, supra note _.

122 Also on September 9 published reports indicated that Nestle and Cadbury were in talks over a possible joint bid for the Hershey Company. See Robert Frank \& Sarah Ellison, Nestle, Cadbury to Discuss Terms of Possible Joint Bid for Hershey, Wall St. J. A3 (Sept. 9, 2002).

123 Brief of Appellee, supra note _, at 11-12.

${ }^{124}$ Id. at 19. Throughout his brief the attorney general took the position that the trust's ultimate beneficiary was the public at large. See, e.g., id. at 5, 14, 19, 21, 22, 23, 26.

$125 \mathrm{Id}$. at 23 (emphasis removed). 
School. ${ }^{126}$ The Deed of Trust also gave the trustees "full power and authority to invest" the trust assets. ${ }^{127}$ Accordingly, because "portfolio diversification is the hallmark of any prudent investor," 128 because the Trust's concentration in Hershey made the trust "twice as risky as the typical college or university" endowment, ${ }^{129}$ and because nothing in the trust instrument made the Trust's investment in the Company "sacrosanct,"130 the trustees argued that it "was improper for the trial court to enjoin" the sale process, which was both "lawful and prudent."131

On Tuesday, September 10, the trial judge rendered a written opinion explaining the issuance of the September 4 injunction; HSY closed at $\$ 74.10$. Calling Zimmerman's testimony "persuasive" and noting the "symbiotic relationship among the School, the community, and the Company," the judge found that a sale of the Trust's "controlling interest in the Hershey Foods Corporation creates a likelihood that there will be reduction in the work force and that relocations of plant operations and closing of duplicate facilities will be matters of probable immediate consideration by the acquiring company." 132 The injunction was therefore necessary to prevent "the adverse economic and social impact" that would result from a sale, "particularly in its effect on employees of the Corporation and the community of Derry Township."133 Put more bluntly (and again quoting the judge), after paying a premium for the Company an acquirer would probably "introduce management efficiencies in order to cut costs to achieve an acceptable return ... . The likelihood is great that these efficiencies will result in reduced work forces with a potential for plant location changes." 134

The judge noted two other factors in favor of issuing the injunction. First, the Trust's income had always exceeded the School's operating expenses. The judge therefore found that the proposed sale "appears to be excessive and unnecessary for any foreseeable needs of the Trust." ${ }^{335}$ Second, in the teeth of the volatility experi-

126 Brief of Appellant, supra note _, at 13, 25. The Deed of Trust provides as follows: "That the parties of the first part [Mr. \& Mrs. Hershey], with the purpose of founding and endowing in perpetuity an institution to be known as 'Milton Hershey School', hereinafter designated School, to be located in Derry Township ...." Id. at 13.

127 Brief of Appellant, supra note _, at 20-21 (quoting the Deed of Trust).

128 Id. at 33-35. Elsewhere in their brief the trustees argued suggested that "if recent events involving the collapse of companies that were pillars of the communities in which they were headquartered-i.e. [sic], Enron, WorldCom, and Adelphia-reveal anything, they reveal that no company, no matter how special and unique the Attorney General attempts to portray it, is immune from market forces and potential adverse economic, business, or financial developments." Id. at 39 (emphasis removed).

129 Id. at 36.

130 Id. at 21.

131 Id. at 36.

132807 A.2d at 331.

133 Id.

134 Id. at 329.

135 Id. at 334. 
enced by HSY on September 4 and 5, the judge rejected as "not compelling" the argument than an injunction would "cause significant fluctuations" in the Company's stock "that will result in possible loss to the School fund."136 The attorney general made a similar argument in his brief on appeal filed on September 10, adding also that "nothing suggests that the stock will be priced differently even if a sale does not occur." 137

The appellate court heard argument the next day, Wednesday, September 11. "Who in the courtroom," the trustees' lawyer asked, "has not read in the paper what happens in today's economy when you invest too heavily in a single stock?"138 The deputy attorney general arguing the case replied that "[t]here is absolutely no support, and in fact the evidence contradicts, that there is a need to sell this company." 139 No timeframe was set for the ruling.

On Tuesday, September 17, 2002, while waiting for the appellate court to render a decision, the trustees gathered in a hotel in Valley Forge for a previously scheduled two-day meeting. ${ }^{140}$ "Despite opposition from a handful of the 17 trustees," the Wall Street Journal reported that morning, "most . . remain committed to at least exploring the sale until a firm offer is on the table."141 HSY closed at $\$ 73.81$ in Tuesday's trading.

What was not publicly known at the time of the Tuesday meeting, however, was that the trustees had set a deadline of Saturday, September 14, for bids for the Company. ${ }^{142}$ The top bid was from the Wm. Wrigley Jr. Company: $\$ 12.5$ billion in cash and stock, which works out to about $\$ 89$ per share. The second best bid was a joint proposal from Nestle and Cadbury, which was valued at $\$ 10.5$ billion, about $\$ 75$ per share. Under the Wrigley proposal, the combined company would be called Wrigley Hershey, and Wrigley also promised to keep the local Hershey factories open (a cruel irony given the Company's 2007 announcement of layoffs). ${ }^{143}$ Because the $\$ 12.5$ billion price would be paid with both cash and stock, accepting the Wrigley bid would not entirely resolve the Trust's diversification problem. But it would reduce the Trust's single-firm concentration to the extent of the cash component of the deal.

136 Id.

137 Brief of Appellee, supra note _, at 29-30.

138 Bill Sulon, Attorneys Debate Role of Hershey Trust Co., Patriot-News (Sept. 12, 2002).

139 Strawley, supra note _.

140 See Sarah Ellison \& Robert Frank, Hershey Trust to Meet Today, Consider Alternatives to Sale, Wall St. J. B6 (Sept. 17, 2002);

$141 \mathrm{Id}$

142 Frank \& Ellison, Meltdown in Chcolatetown, supra note _.

143 See Andrew Ross Sorkin, Hershey Trust Halts Auction Despite Offer of $\$ 12$ Billion, N.Y. Times C1 (Sept. 18, 2002) (hereinafter Sorkin, Trust Halts); Sarah Ellison \& Nikhil Deogun, Hershey Trust Calls Off Sale of Firm-Board Was Set to Meet to Accept $\$ 12.5$ Billion Bid from Wm. Wrigley Jr. Co., Wall St. J. A3 (Sept. 18, 2002). On the 2007 announcement of layoffs, see infra note 290 and text accompanying. 
According to subsequent media reports, the trustees' Tuesday session was "emotional," "rancorous," and "sometimes teary," with the trustees feeling "embittered" by what they perceived to be "pressure" from the attorney general's office to diversify followed by the attorney general's heated opposition. ${ }^{144}$ Having become the objects of calumny, the trustees felt "overwhelmed by the outcry of protest from the community." 145 The chairman of the board of trustees, who had received death threats, had been living with an armed guard assigned to his home. ${ }^{146}$ The trustees deliberated for 10 hours. William Wrigley delivered a "moving" speech in which he discussed the significance of adding Hershey to his eponymous company's name and promised a commitment to the Hershey community. Just before midnight, however, the trustees announced that they had voted 10 to 7 to reject Wrigley's bid and all the other bids too. ${ }^{147}$

The trustees' decision was met by Hershey residents and workers with a mix of relief and joy. "All I can say is hooray," one resident told the associated press. "I still want this company to be around for my grandchildren, so they can work here when they're old enough," said another. ${ }^{148}$ Kathy Taylor, a local lawyer and former town supervisor who helped spearhead the "Derail the Sale" movement, offered a more blunt assessment to the The New York Times: "Our cash cow is safe; we're feeling really great." ${ }^{449}$ In something of an anticlimax, also on Wednesday the appellate court upheld the trial judge's injunction by a 4 to 1 vote. ${ }^{150}$

Investors took a dim view of the sale's cancellation. On Wednesday, September 18 , HSY closed at $\$ 65$, down $\$ 8.81$ (almost 12 percent) from Tuesday's closing price of $\$ 73.81$. Some 20 million HSY shares traded on Wednesday, 10 times the number that traded on Tuesday.

The trustees did not fare well in the aftermath. On October 16, the Orphans' Court dissolved the injunction but retained jurisdiction and ordered that the Trust give the attorney general's office "prompt written notice" of any future intention to sell its controlling interest in the Hershey Company (the trustees had previously

144 Ellison \& Deogun, supra note _; Sherri Day \& Andrew Ross Sorkin, Candy Giants Both Show New Faces In Failed Deal, N.Y. Times C1 (Sept. 19, 2002).

145 Sorkin, Trust Halts, supra note _.

146 D'Antonio, supra note _, at 263-64.

147 See Frank \& Ellison, Meltdown in Chocolatetown, supra note _ ; Ellison \& Deogun, supra note _; Sorkin, Trust Halts, supra note _.

148 Raffaele, supra note _.

149 Clines, supra note _.

150 The majority held that it could reverse the judge only if there were "no reasonable grounds" for the injunction, and a "review of the record and [the judge's] opinion does not immediately convince us no apparently reasonable grounds exists.” 807 A.2d at 327. 
promised in writing to do so $\left.{ }^{151}\right)$. The judge also criticized the trust board as being too large and too "distant and disconnected from the charitable interests they serve."152 On November 14, Fisher announced that the 7 trustees who had voted in favor of continuing the sale would be stepping down in favor of 4 new board members, all hailing from central Pennsylvania. ${ }^{153}$

Fisher, too, faced disappointment-at least initially. His announcement of the change in the trust board came a week after he lost the gubernatorial election by almost 10 percent. ${ }^{154}$ Prior to the election, Fisher had run television ads in which he claimed to have saved over 6,000 Hershey jobs. ${ }^{155}$ In May of 2003, however, President George W. Bush nominated Fisher to be a circuit judge for the United States Court of Appeals for the Third Circuit, and the Senate confirmed Fisher's appointment on December 9, 2003. ${ }^{156}$

The aborted sale also affected Pennsylvania law, which already deviated from the norm by exempting the trustees of existing trusts from the duty to diversify. ${ }^{157}$ On November 6, 2002, the governor signed an amendment to the Pennsylvania prudent investor statute. As amended, the statute required the trustees of a charitable trust "in making investment and management decisions" to consider "the special relationship of [a trust asset] and its economic impact as a principal business enterprise on the community." 158 The amendment also barred a trustee of a charitable trust "holding a controlling interest in a publicly traded business corporation received as an asset from the settlor" from selling that controlling interest without first notifying the attorney general and the Pennsylvania employees of the business. If the attorney general challenged, the amendment put the burden on the trustee to "prove by clear and convincing evidence" that the sale "is necessary to maintain the economic viability of the corporation and [to] prevent a significant diminution of trust assets or to avoid an impairment of the charitable purpose of the trust." 159 The amendment represents a radical departure from orthodox principles of prudent trust

151 See Sarah Ellison, Hershey Foods' Controlling Trust Says it Has "No Intentions to Sell," Wall St. J. B5 (Sept. 27, 2002); The Hershey Company, Form 10-K, Annual Report for the fiscal year ended December 31, 2006, at 25.

152 Tamar Lewin, 10 Board Members to Leave Hershey's Charitable Trust, N.Y. Times A5 (Nov. 15, 2002); Sidel, supra note _, at 29-30.

153 See Lewin, supra note _; Sidel, supra note _, at 31.

154 The 2002 Elections: Northeast; Pennsylvania, N.Y. Times B12 (Nov. 7, 2002).

155 Industry Representatives Assail Pennsylvania Trust-Regulation Bill, Patriot-News (Oct. 29, 2002).

156 See http://www.whitehouse.gov/news/nominations/475.html. Judge Fisher serves with Judge Marjorie O. Rendell, the spouse of Ed Rendell, the Democratic Party candidate who beat Fisher in the gubernatorial election.

157 See supra note 15 and text accompanying.

158 See Act No. 2002-133, H.B. No. 2060, amending 20 Pa. Stat. §7203.

159 Id. 
investment law. ${ }^{160}$ Nonetheless, it was popular in Pennsylvania. The state Senate majority leader captured the local view: "We have to be active and protect our economic assets."161

As detailed in Table 1 above, in spite of occasional share repurchases by the Company, ${ }^{162}$ the Trust remains overwhelmingly invested in the Company and, hence, manifestly undiversified.

\section{B. Charitable Trusts}

A private trust is a fiduciary relationship in which the trustee holds legal title to specified property, entrusted to him by the settlor, and manages that property for the benefit of one or more beneficiaries. Hence, the trust presents the standard agency problem that arises when risk-bearing (the beneficiaries) and management (the trustee) are separated.163 To safeguard the beneficiary from mismanagement or misappropriation by the trustee, trust law supplies a set of default terms known as fiduciary duties that prescribe the trustee's level of care (the duty of prudence) and proscribe misappropriation (the duty of loyalty). ${ }^{164}$ A beneficiary who believes that the trustee acted disloyally or imprudently may sue the trustee for breach of trust. Moreover, because trust default law makes it difficult for the beneficiary to remove the trustee, and because the beneficiary's interest is typically inalienable (i.e., there is no market for trust control), the threat of fiduciary litigation is the primary force for aligning the interests of the trustee and the beneficiary - that is, for minimizing agency costs in the modern private trust. ${ }^{165}$

The paramount role of fiduciary law in minimizing agency costs in trust governance explains the traditional rule that a private trust must be for the benefit of an ascertainable beneficiary. ${ }^{166}$ Requiring an ascertainable beneficiary ensures that

\footnotetext{
160 Others have remarked the unusual nature of the Pennsylvania statute. See, e.g., Dale, supra note _; Sidel, supra note _ , at 44-48; Fremont-Smith, supra note _, at 193. See also infra note 288 and text accompanying (quoting the official comment to the Uniform Prudent Investor Act).

161 Charles Thompson, Future Hershey Sale Obstacles OK'd, Patriot News, October 10, 2002, at B1.

162 See The Hershey Company, Form 10-K, Annual Report for the fiscal year ended December 31, 2006 , at 28,83 .

163 See Sitkoff, supra note _, at 623-25, 648-49.

164 See John H. Langbein, The Contractarian Basis of the Law of Trusts, 105 Yale L.J. 625, 640-42, 655-60 (1995); Frank H. Easterbrook \& Daniel R. Fischel, Contract and Fiduciary Duty, 36 J. L. \& Econ. 425, 426 (1993); Robert Cooter \& Bradley J. Freedman, The Fiduciary Relationship: Its Economic Character and Legal Consequences, 66 NYU L. Rev. 1045, 1047 (1991).

165 See Langbein, supra note _, at 640-43; Sitkoff, supra note _, at 677-78; Robert H. Sitkoff, Trust Law, Corporate Law, and Capital Market Efficiency, 28 J. Corp. L. 565, 570-71, 577-78 (2003); Dukeminier et al., supra note _, at 775. See also Schanzenbach \& Sitkoff 2007, supra note _, at _, on which this paragraph draws.

166 See Restatement (Third) of Trusts $§ 44$ (2003); Uniform Trust Code $§ 402(a)(3)$
} 
there is someone who has an economic incentive to enforce the trustee's fiduciary duties. ${ }^{167}$

Unlike a private trust, however, a charitable trust must be for a charitable purpose such as advancing education or the relief of poverty (hence the validity of the Hershey Trust)—not for a specific beneficiary. ${ }^{168}$ "Even if individuals receive direct benefits from a charitable trust, such as scholarship grants, money, food, clothing, or any other direct assistance, they are considered the "conduits of the social benefits to the public and are not in reality the beneficiaries of the trust."'169 Hence, in a charitable trust there is no identifiable beneficiary with an economic incentive and legal standing to ensure "that the trustee acts in accord with the settlor's charitable purpose and refrains from abuse or breach of fiduciary obligation." 170 Evelyn Brody aptly frames the resulting agency problem thus: "In the case of an entity having no owners and established for the benefit of indefinite beneficiaries, who is the principal on whom the law can rely to monitor the agents and force the charitable purpose?"171

The traditional answer to the problem of agency costs in charitable trusts is to vest the state attorney general, as parens patriae, with standing to enforce such trusts. ${ }^{172}$ Indeed, many states have broadened the attorney general's common law enforcement power to include the power to investigate the operation of charitable entities. ${ }^{173}$ Most states require charitable trusts and other charitable entities to make regular reports to the attorney general's office (a disclosure requirement that

167 Empirical study suggests that trustee behaviors is indeed sensitive to changes in default trust fiduciary law. See Schanzenbach \& Sitkoff 2007, supra note _, at _.

168 The list of valid charitable purposes, which traces back to the Statute of Charitable Uses, 43 Eliz. I, ch. 4 (1601), is "(a) the relief of poverty; (b) the advancement of knowledge or education; (c) the advancement of religion; (d) the promotion of health; (e) governmental or municipal purposes; and (f) other purposes that are beneficial to the community.” Restatement (Third) of Trusts $\S 28$ (2003). Uniform Trust Code $§ 405(\mathrm{a})$ (2000) and Principles of the Law of Nonprofit Organizations $§ 210$ (P.D. No. 4, 2007) state virtually identical lists. The rules for qualifying as charitable under the tax code are similar, with differences that are immaterial to this study. See I.R.C. 501(c)(3); Treas. Reg. 1.501(c)(3)-1. See also Principles of the Law of Nonprofit Organizations Reporter's Notes 10-14 to §210 (comparing state law to federal tax law); Fremont-Smith, supra note _, at 238-300 (canvassing tax rules applicable to charitable entities).

169 Fremont-Smith, supra note _, at 128. Thus, in a December 2006 decision that is representative of traditional law, the Pennsylvania Supreme Court confirmed that the Hershey School's alumni association did not have standing to sue the trustees for breach of trust. See In re Hershey School and Trust, 911 A.2d 1258 (Pa. 2006).

170 Dukeminier et al., supra note _, at 730.

${ }^{171}$ Brody, supra note _, at 1429.

172 See Restatement (Second) of Trusts $\$ 391$ (1959). Parens patriae means "parent of the country" and has traditionally be used to refer to the power of the state to act on behalf of those who cannot act for themselves.

173 See, e.g., Fremont-Smith, supra note _, at 317-18, Appendix Table 1; Craig Kaufman, Sympathy for the Devil's Advocate: Assisting the Attorney General When Charitable Matters Reach the Courtroom, 40 Real Prop. Prob. \& Tr. J. 705, 725-26 (2005) (collecting illustrative statutes); James J. Fishman, Improving Charitable Accountability, 62 Md. L. Rev. 218, 259-62 (2003) (same). 
is backstopped by federal law applicable to tax-exempt entities). ${ }^{174}$ And in many instances, the state attorney general is a necessary party in litigation involving a charitable trust or other charitable entity. ${ }^{175}$

But the state attorney general is a political official, typically elected, with neither a personal financial stake nor, in the usual case, a political stake in the operation of a charitable trust. Many states have few (if any) lawyers assigned to enforcement of charities, and even in those that do, it is the politically salient, egregious cases that "trigger investigations," not "reviews of annual reports."176 Unless an alleged breach of trust obtains enough media attention to achieve political salience, actual scrutiny of a charitable trust by the attorney general is unlikely. ${ }^{177}$ In the usual case there simply isn't enough of a political payoff to the attorney general to warrant the diversion of resources from other initiatives. ${ }^{178}$ Once again, Evelyn Brody provides the apt summation: "Political cynics believe that 'A.G.' stands not for 'attorney general' but for 'aspiring governor."'179 Accordingly, a diverse array of scholars have theorized that supervision of charitable trusts by the attorneys general is lackadaisical and hence the trustees of charitable trusts lack an incentive to manage the trust's assets in an efficient manner. ${ }^{180}$

For example, Richard Posner has written that "neither the trustees nor the staff" of a charitable entity has "a strong incentive to maximize value."181 Henry Hansmann observes that "in most states there has been little effort to exercise even the substantial powers that the attorney general already has."182 Marion Fremont-

174 See Fremont-Smith, supra note _, at 311-17, Appendix Table 1. See also Susan Gary, Regulating the Management of Charities: Trust Law, Corporate Law, and Tax Law, 21 U. Haw. L. Rev. 593, 619-22 (1999) (collecting state and federal disclosure rules).

175 See Fremont-Smith, supra note _, at 318-19, Appendix Table 1; Kaufman, supra note _, at 724.

176 See Gary, supra note _, at 622-24.

177 Even then, it is often the media, not the attorney general, that initially brings the trustees' misconduct to light. A recent example concerns the J. Paul Getty Trust, "one of the world's richest cultural organizations," into which the California attorney general investigated only after "reports of questionable expenses and suspect grants" appeared in The Los Angeles Times. See Edward Wyatt \& Randy Kennedy, California Attorney General Appoints Overseer of Reforms at J. Paul Getty Trust, N.Y. Times E1 (Oct. 3, 2006).

178 See Dukeminier et al., supra note _, at 760; John H. Langbein, The Uniform Trust Code: Codification of the Law of Trusts in the United States, 15 Tr. L. Int'l 66, 67-68 (2001). See also Mary Grace Blasko et al., Standing to Sue in the Charitable Sector, 28 U.S.F. L. Rev. 37, 48-49 (1993) ("Lack of resources and lack of interest thus both contribute to the current insufficiency of attorney general enforcement.").

179 Brody, Parochialism, supra note _, at 946.

180 The literature typically credits Kenneth L. Karst, The Efficiency of the Charitable Dollar: An Unfulfilled State Responsibility, 73 Harv. L. Rev. 433 (1960), as its foundation. Karst wrote that "supervision and enforcement" of charities by the attorney general "have been irregular and infrequent." Id. at 437.

181 Posner, supra note__, $\$ 18.5$, at 547.

182 Henry B. Hansmann, Reforming Nonprofit Corporation Law, 129 U. Pa. L. Rev. 497, 601 (1981). 
Smith has written of "the failure of all but a handful of states to police [charitable] fiduciary behavior." 183 Harvey Dale has said that the state attorneys general "tend to allocate their scarce regulatory resources to other more politically potent portions of their domains. In most states, the Charity Bureau of the Attorney General is inactive, ineffective, overwhelmed, or some combination of these."184 Evelyn Brody observes that "as a practical matter, few state attorneys general have the funding and inclination to engage in aggressive charity enforcement." 185 Alex Johnson concludes that "attorneys general collectively have failed in their obligation to effectively monitor and pursue breaches of duty" in charitable trusts. ${ }^{186}$ Dana Brakman Reiser has noted the "significant resource and structural issues unique to the nonprofit context" that make enforcement difficult. ${ }^{187}$ Ronald Chester laments the "increasingly obvious ... need for better policing methods for charities" given the ineffectiveness of the "politically-influenced attorneys general."188 Susan Gary supposes that "[t]he worst abuses receive attention, but many problems probably go undetected or unaddressed."189 Craig Kaufman has written of the "passive," "erratic," and "deficient oversight of charitable matters" owing to resource constraints and the reality "that attorneys general are political officials." ${ }^{190}$ Judges, too, have long made similar observations. ${ }^{191}$

Although there is anecdotal evidence that is consistent with the widely-held assumption of agency costs in charitable trusts, ${ }^{192}$ there exists no quantitative empirical study of the issue-a gaping hole in the literature. The Hershey Trust's 2002 aborted sale of the Hershey Company provides a unique opportunity to begin filling that lacuna. Specifically, daily stock price data from before, during, and after the

183 Fremont-Smith, supra note _, at 13.

184 Dale's remarks are quoted in Peter Swords, Nonprofit Accountability: The Sector's Response to Government Regulation, 25 Exempt Org. Tax Rev. 413, 413 (1999).

185 Brody, Parochialism, supra note _, at 939.

186 Alex M. Johnson, Jr., Limiting Dead Hand Control of Charitable Trusts: Expanding the Use of the Cy Pres Doctrine, 21 U. Haw. L. Rev. 353, 388 (1999).

187 Dana Brakman Reiser, There Ought to Be a Law: The Disclosure Focus of Recent Legislative Proposals for Nonprofit Reform, 80 Chi.-Kent L. Rev. 561, 598-06 (2005) (hereinafter "Reiser, Disclosure”). See also Dana Brakman Reiser, Decision-Makers Without Duties, 53 Rutgers L. Rev. 979, 102022 (2001).

188 Ronald Chester, Improving Enforcement Mechanisms in the Charitable Sector: Can Increased Disclosure of Information Be Utilized Effectively?, 40 New Eng. L. Rev. 447, 452 (2006).

189 Gary, supra note _, at 624.

190 Kaufman, supra note _, at 726-27.

191 See, e.g., Soughegan Nat. Bank v. Kenison, 26 A.2d 26, 30 (N.H. 1942) (The attorney general "is unorganized and underequipped to enforce [charitable] trusts . . . The result is that the office acts only in sporadic instances when complaint is made or instructions sought.").

192 Perhaps the best known example concerns the egregious mismanagement of the Hawaii Kamehameha Schools/Bishop Estate in the late 1990s. See Samuel P. King \& Randall W. Roth, Broken Trust: Greed, Mismanagement, and Political Manipulation at America's Largest Charitable Trust (2006); Dukeminier et al., supra note _ , at 763-66. In a related vein, there have been occasional studies detailing the insufficiency of resources allocated to charity enforcement, see 176, and studies of agency problems in not-for-profit firms, see, e.g., Core et al., supra note 
aborted sale provide a measurement of the value of a prominent charitable trust's principal asset (i.e., a controlling interest in the Hershey Company) while in the hands of the trustees versus when that asset was for sale on the open market. These price data also allow for assessment of the welfare effects of an intervention by a state attorney general in a publicly salient case.

We posit that effective trustees would already have realized for the Trust the benefits of holding a controlling interest in the Hershey Company by using their controlling vote block to impose a value-maximizing strategy on the Company's managers. Such efficiency-inducing actions would inure to the benefit of all the shareholders in the form of a higher stock price. We therefore hypothesize that, controlling for general market trends, the sale announcement should not have had a positive effect on the value of Hershey shares not held by the Trust. On the contrary, a sale would end the ability of the other shareholders to free-rise on the trustees' value-inducing efforts. Thus, if the trustees had been successfully imposing a value-maximizing strategy on the Company's managers, we would expect if not a negative then at least a neutral price effect from the sale announcement. By contrast, a positive effect would imply that the takeover threat associated with the market for corporate control better disciplined the Hershey Company's managers than the trustees in spite of the trustees' controlling vote block.

We must acknowledge, however, two important limitations in the foregoing research design: (1) a positive result might be consistent with an alternative hypothesis, and (2) our study is by necessity limited to a single charitable trust. We consider each limitation in turn.

(1) Alternative hypotheses. A positive finding is arguably consistent not only with the charitable trust agency cost hypothesis that we state above, but also with two alternative hypotheses: (a) escape from the trustees' non-profit-maximizing objectives, and (b) the control premium phenomenon. ${ }^{193}$

(a) Non-profit-maximizing objectives. The first alternative hypothesis is that the trustees' controlling interest was bad for the stock price of the Company not because the trustees were lax in monitoring the Company's managers, but rather because the trustees imposed policies that favored the interests of the Trust to the detriment of the other shareholders. On this account, the sale announcement would lead to an increase in the price of the Company's stock by freeing the Company's managers to pursue a profit-maximizing strategy. This account comes in strong and weak forms.

193 Given the Company's dual class stock arrangement, see supra note 13 and text accompanying, it might be thought that changes in the relative voting and dividend rules occasioned by the sale might affect the Company's stock price. However, the trustees instructed the Company to solicit bids for a takeover that would be implemented by a merger. In such a merger, all the Company's shares would be exchanged for cash or for cash and stock in the acquiring Company. Because all Hershey shares would disappear at the same time, there would be no change in relative rights among the Hershey stockholders. 
The stronger but less plausible form is that the trustees imposed unequal distributions or other payments to the Trust not shared pro rata with the other shareholders. However, to have affected the stock price positively on news of the sale, the fact of non pro rata treatment must have been publicly available. Yet our review of the public record for the relevant timeframe uncovered no evidence of such favoring. Further, an accepted principle of corporate fiduciary law holds that a controlling shareholder may not secure a pecuniary or other benefit from the company that is not shared proportionally with the other company's other shareholders. ${ }^{194}$

The weaker but more plausible version of this alternative hypothesis is that the trustees imposed a cautious, risk-averse style of management on the Company that favored stable dividends and low risk projects at the expense of the sort of higher risk (but positive net expected value) projects that in the long run are more likely to maximize the return on the firm's underlying assets. For example, suppose the Company could pursue project $A$ or project $B$, but not both. Project $A$ offers a certain return of $\$ 100$ while project $B$ offers a 60 percent chance of a $\$ 200$ return (hence an expected return of $\$ 120$ ). Diversified shareholders would prefer project $B$ because in the aggregate such shareholders will win often enough to offset the less frequent occasions that they loose. ${ }^{195}$ However, because the Trust is not well diversified, the trustees might prefer the certainty of project $A$ in spite of its lower expected value. ${ }^{196}$

When viewed in this manner, however, this alternative hypothesis is revealed to be merely a reformulation of ours. The trustees failed to maximize the value of the Trust's most significant asset, its shares in the Company, by sacrificing value for a reduced level of risk that could have been achieved without the loss in value. If the trustees judged the risk associated with a profit-maximizing Hershey Company to be too great for the Trust to bear, then they could have sold the Trust's shares, realizing the increased price from the market's expectation of the Company's switch to profit-maximization once free of the Trust's control. The trustees could then have invested the resulting larger Trust corpus in a diversified portfolio with the desired balance of risk and return, except the new portfolio would be both diversified and in the aggregate larger.

The key point is that regardless of the mechanism for the depressed price of the Company's stock-lax monitoring of the Company's managers or imposition of something other than a profit-maximizing strategy-the implication of a positive finding is the same. The trustees unnecessarily sacrificed value, reducing the assets

194 See ALI Principles of Corporate Governance §5.11 (1994); James D. Cox, Thomas Lee Hazen, \& F. Hodge O’Neal, 1 Corporations $§ 11.10$ (2002). As one of us has observed elsewhere, "dominant shareholders are held to all the same fiduciary standards that ordinarily apply to management." Robert H. Sitkoff, Corporate Political Speech, Political Extortion, and the Competition for Corporate Charters, 69 U. Chi. L. Rev. 1103, 1122 (2002).

195 See Sitkoff, supra note _, at 655-57; Joy v. North, 692 F.2d 880, 886 (2d Cir. 1982) (Winter, J.).

196 See D'Antonio, supra note _ , at 246 (suggesting that the trustees were "interested in minimizing risk and pressed the company for consistent performance rather than quick profits"). 
available for the Trust's charitable purpose while at the same time exposing the Trust's investment portfolio to uncompensated risk.

(b) The control premium phenomenon. The second alternative hypothesis posits that a positive result could reflect nothing more than the control premium phenomenon. A controlling interest in a publicly-traded company sometimes has a control premium attached to it independent of any beliefs about the firm's underlying value. On this account, the trustees might have been active, efficient monitors of the Company's managers, but owing to a potential buyer's managers' desire to build a larger empire or to become too big to be a takeover target or for some other reason a buyer might nonetheless value a control block in the Hershey Company more highly than the sum of the market's valuation of the individual shares. ${ }^{197}$ A purchaser also might be willing to pay a premium in anticipation of the synergies created by the merger. ${ }^{198}$

However, the control premium possibility bears only on the mechanism for, not the existence of, agency costs in the Hershey Trust's management. Because the trustees already had a controlling interest in the Company, they should have exploited the existence of a potential control premium for the Trust's charitable purpose, if not directly by imposing superior management on the Company (our original hypothesis), then indirectly by selling the Company to a buyer that for whatever reason values control more highly (this alternative hypothesis). Under either scenario, the trustees left money on the table that could have been realized for the benefit of the Trust's charitable purpose.

(2) A single charitable trust. The second limitation in our research design is that our study is limited a single charitable trust. Here the worries concern our econometric methodology (i.e., internal validity) and the generalizability of our results (i.e., external validity). With respect to internal validity, the concern is that with only a single trust the noise to signal ratio might be such that we ascribe statistical significance to what is in fact a random fluctuation in the data. To address this concern, we undertake a host of robustness checks, several of which are designed specifically to address the problem of noise in a sample of one. ${ }^{199}$ We may also take comfort from the fact that the magnitudes of some of our findings are so large that,

197 In this account, the control premium stems from agency costs within the acquiring firm. Managers' preferences for an acquisition that does not necessarily benefit the acquiring company's shareholders can arise, for example, from the desire to build an empire (which has both psychic benefits and offers takeover protection) or to build a conglomerate for which evaluation of management quality is difficult. See, e.g., John C. Coffee, Jr., Regulating the Market for Corporate Control: A Critical Assessment of the Tender Offer's Role in Corporate Governance, Colum. L. Rev. 1145, 1157 (1984); Michael Jensen, Agency Costs of Free Cash Flow, Corporate Finance and Takeovers, 76 Am. Econ. Rev. 323 (1986); Yakov Amihud \& Baruch Lev, Risk Reduction as a Managerial Motive for Conglomerate Mergers, 12 Bell J. Econ. 605 (1981).

198 Strictly speaking, the synergy scenario might more properly be understood as an agency cost on the part of the trustees. If such synergies existed, value-maximizing trustees would have used their control to force the Company to exploit those synergies, for example by initiating a merger.

199 See infra Part III.C.4. 
as a mathematical matter, they cannot be artifacts of random fluctuation in the data. ${ }^{200}$

Regarding external validity, the concern is that our findings with respect to the Hershey Trust might not be representative of other charitable trusts more generally. Here the tension is between the quality of the natural quasi-experiment (the more unusual the circumstances, the better the experiment) and the generalizability of the results. Given the unique shock of the trustees' exposing the Hershey Company to the market for corporate control, we must guard against reading our results more aggressively than our research design can justify.

Accordingly, a positive result would indicate agency costs in the Hershey Trust structure and would tend to support the large body of theoretical literature that supposes agency costs in charitable trusts more generally. We cannot, however, generalize about the magnitude of agency costs in other charitable trusts from the magnitude of our specific Hershey finding, as each charitable trust operates in a different context. Still, a very large positive finding might imply that the problem is worse than previously believed, as the Hershey Trust has a high profile in Pennsylvania. A negative result, by contrast, would indicate that this charitable trust was well managed, but given the Hershey Trust's political salience in Pennsylvania, a negative result would not negate the claim in the theoretical literature that lower profile charitable trusts are often poorly managed.

\section{Corporate Governance}

As in trust law, minimizing agency costs is a central concern of corporate law. In the corporate context, agency problems arise from what Berle and Means famously dubbed the corporate form's "separation of ownership and control"- that is, the separation of the risk-bearing residual claim, which is held by the shareholders, from managerial authority, which is held by the directors and senior management. ${ }^{201}$ To align the incentives of managers with the interests of shareholders, or at least to constrain the extent to which managers can advance their own interests at the expense of shareholders, the law gives shareholders information rights, the right to sue, the right to vote on the composition of the board and to approve certain critical transactions, and the right to sell their shares.

With respect to the large, publicly-traded corporation, the prevailing scholarly view, which is supported by abundant empirical evidence, is that shareholder litigation and other such control mechanisms are weak devices for minimizing corporate agency costs when compared to the market for corporate control (i.e., the threat of a takeover). ${ }^{202}$ Diffuse shareholders are plagued by collective action prob-

\footnotetext{
200 See infra Appendix C.

201 See Adolf A. Berle, Jr. \& Gardiner C. Means, The Modern Corporation and Private Property 6970 (1932). For more modern statements, see Bainbridge, supra note _, at 35-38; Roberta Romano, Foundations of Corporate Law v (1993).

202 Michael Jensen famously expressed this view in his 1993 Presidential Address to the American Finance Association. See Michael C. Jensen, The Modern Industrial Revolution, Exit, and the Failure
} 
lems, leaving each individual shareholder hesitant to engage in litigation, which is in effect a public good. A litigating shareholder will bear most of the litigation costs, but because the typical shareholder owns a tiny percentage of the company, the resulting gains from reducing corporate agency costs will accrue mainly to the other shareholders. ${ }^{203}$ The same intuition applies to other internal control mechanisms such as the right to vote. No individual shareholder has a real incentive to fight for controls that would benefit all shareholders or to engage in the sort of active monitoring that leads to informed voting.

The analysis is different when one considers the potential disciplining force of the threat of a takeover. If managers do not maximize the return on a firm's assets, the firm's stock price will be depressed. This depressed stock price represents a profit opportunity for an investor or group of investors that acquires a controlling interest in the firm and replaces the existing management team with one that maximizes the return on the firm's assets. The payoff is the resulting appreciation in the firm's stock price. Accordingly, by threatening managers with the loss of their jobs in the event that they shirk or under-perform, the market for corporate control minimizes corporate agency costs. ${ }^{204}$ On this account the right to vote and the right to sell are key for good corporate governance not in their own right, but because they facilitate the operation of the market for corporate control.

An alternative disciplining mechanism arises when the firm has a controlling shareholder or a minority blockholder. Unlike a typical shareholder, for whom diversification plus passivity is a rational strategy, a controlling shareholder might have a sufficient financial incentive to monitor actively and, if necessary, impose new management or new managerial strategies on the company. ${ }^{205}$ Thus, some scholars and policymakers have argued that increased activism by such shareholders will improve corporate governance. ${ }^{206}$ On the other hand, the extent of the discipline provided by a controlling shareholder will depend on the controlling sharehold-

of Internal Control Systems, 48 J. Fin. 831, 850 (1993). For a recent review of the empirical literature, see Bhagat \& Romano, supra note _, at 46-49, 61-70, 106-108 (Table 3). See also Michael Jensen \& Richard Ruback, The Market for Corporate Control: The Scientific Evidence, 11 J. Fin. Econ. 5 (1983); Gregg A. Jarrell, James A. Brickley, \& Jeffrey M. Netter, The Market for Corporate Control: The Empirical Evidence Since 1980, 2 J. Econ. Persp. 49 (1988).

203 For discussion of agency problems in shareholder litigation, see, e.g., Reinier Kraakman et al., When Are Shareholder Suits in Shareholder Interests?, 82 Geo. L.J. 1733 (1994).

204 See, e.g., Easterbook \& Fischel, supra note _, at 171-74; Manne, supra note _.

205 See Andrei Shleifer and Robert W. Vishny, Large Shareholders and Corporate Control, 94 J. Pol. Econ. 461 (1986).

206 See, e.g., Ronald J. Gilson \& Reinier Kraakman, Reinventing the Outside Director: An Agenda for Institutional Investors, 43 Stan. L. Rev. 863 (1991); Bernard S. Black, Agents Watching Agents: The Promise of Institutional Investor Voice, 39 UCLA L. Rev. 811, 813 (1992). For contrary analysis, see Thomas A. Smith, Institutions and Entrepreneurs in American Corporate Finance, 85 Cal. L. Rev. 1 (1997); Stephen M. Bainbridge, Director Primacy and Shareholder Disempowerment, 119 Harv. L. Rev. 1735, 1752 (2006). See also Roberta Romano, Less Is More: Making Institutional Investor Activism A Valuable Mechanism of Corporate Governance, 18 Yale J. Reg. 174, 187 (2001) (surveying the empirical literature on institutional activism and concluding that, in general, such activism does not improve shareholder wealth). 
ers incentives and, if the controlling shareholder is itself an entity, the quality of the controlling shareholder's internal governance scheme. On this view, an individual or a well-managed, profit-maximizing hedge fund ${ }^{207}$ might be a more effective monitor than a pension fund ${ }^{208}$ or mutual fund run by managers with an attenuated stake $^{209}$ in the ultimate performance of the fund.

The aborted 2002 sale of the Hershey Company by the Hershey Trust provides a fortuitous natural quasi-experiment on the comparative virtues of a controlling shareholder versus the market for corporate control as alternative mechanisms for minimizing corporate agency costs. If the two mechanisms are equally effective in disciplining management, we should find no difference in the value of the Hershey Company during the sale window and during the periods immediately before and after that window. By contrast, if the market for corporate control is superior to the control provided by concentrated ownership, either because blockholders are generally ineffective, because the managers of this particular blockholder (i.e., the trustees) have poor incentives owing to the agency problems that are inherent to the charitable trust form, or some combination of the two, we should find that Hershey's market value improves during the sales window. If the market for corporate control is inferior to control by the Trust in disciplining management, we should find that Hershey is worth less during the sales window.

As in our analysis of charitable trust agency costs above, however, we must again acknowledge potential limitations in our research design concerning (1) alternate hypotheses and (2) reliance on observations of a single firm.

(1) Alternate hypotheses. We cannot disentangle the role of the Hershey Trust's particular governance structure from the role of switching from a controlling shareholder to the market for corporate control as alternative explanations for the Hershey Company's price dynamics in and around the sale window. Thus, if we have a positive finding - that is, if we find that the Company is more valuable when subject to the takeover market than when under the thumb of the trustees-we will know only that the market rated the threat of a takeover as superior to control by this controlling shareholder. Although such a result would highlight the problem of agency costs within a controlling shareholder's organization form and would lend modest support to the takeover model, it would not resolve whether the takeover market would be preferred to another controlling shareholder with better internal governance (for example, a hedge fund).

207 See Kahan \& Rock, supra note _.

208 Compare Bernard S. Black, Shareholder Passivity Reexamined, 89 Mich. L. Rev. 520, 606 (1990) (arguing that public pension funds are well suited to engage in pro-shareholder activism), with Roberta Romano, Public Pension Fund Activism in Corporate Governance Reconsidered, 93 Colum. L. Rev. 795 (1993) (arguing that public pension funds have their own perverse incentives to take positions potentially in conflict with shareholder interests generally).

209 This point is made quite forcefully in Edward B. Rock, The Logic and (Uncertain) Significance of Institutional Shareholder Activism, 79 Geo. L.J. 445, 464-478 (1991). See also John C. Coffee, Jr., Liquidity Versus Control: The Institutional Investor as Corporate Monitor, 91 Colum. L. Rev. 1277, 1338 (1991) (proposing reforms to overcome fund managers' attenuated incentives to monitor actively). 
Further, to the extent that a positive finding is traceable to agency costs in this controlling shareholder, per our discussion in the prior Section of alternate hypotheses relating to charitable trust agency costs, we cannot determine the specific form of the trust's agency costs (e.g., lax oversight by the trustees, imposition of something other than a profit-maximizing strategy by the trustees, etc.). Accordingly, our analysis will add to the stock of empirical knowledge on controlling shareholders and the takeover market as alternative devices for minimizing corporate agency costs, but the interpretation of our findings must be sensitive to our inability to disentangle how much of our findings are attributable to general versus specific features of the Hershey incident.

(2) A single firm. As before, we must consider the possibility that we might ascribe statistical significance to what is in fact random variation in the data because we examine only a single firm. ${ }^{210}$

\section{EMPIRICAL ANALYSIS}

In this Part we examine the Hershey Company's share prices before, during, and after the period in which the trustees announced their intention to sell the Trust's controlling interest in the Company. Our analysis proceeds in four steps. First, in Section A, we describe the nature and sources of our stock market data. Second, in Section B, we undertake a graphical analysis of the data for the Hershey Company by itself and in comparison to its leading competitors and to the stock market as a whole. The stock price effects of the trustees' plan to sell and abandonment of the sale are so profound that simple graphical depictions are highly suggestive. Third, in Section C, we present the results of a more formal event study econometric analysis that measures stock price movements traceable to sale-related events by isolating them from movements related to ordinary market volatility. Finally, in Section D, we offer a non-technical summary of our main empirical findings. Readers interested in our results, but not the formal methodology, will find Sections B and D of principal interest.

\section{A. Data}

We examine daily closing price data for the Hershey Company's common stock (ticker symbol HSY), the common stock of Hershey's closest competitors that are traded on the New York Stock Exchange (NYSE), and a variety of market indexes including the Standard and Poor's 500 (S\&P 500) and the Dow Jones Industrial Average (DJIA). Our timeframe includes the period under which the sale was considered (that is, between July 25, 2002 and September 18, 2002), two years before the sale window, and two years after the sale window. We include two years before and after the sale window to put the observed price movements during the window into historical perspective.

210 See text accompanying supra notes 199-200. 
We obtained our stock price data from the Center for Research in Stock Prices (CRSP) at the University of Chicago Graduate School of Business. ${ }^{211}$ We accessed these data through the Wharton Research Data Service, ${ }^{212}$ an interface maintained for academic use at the University of Pennsylvania.

A problem with raw stock price data spanning several years is that price movements may reflect nothing more than a stock split or a dividend payment, which do not affect shareholder wealth. For example, suppose Company $A$ has 100 shares trading at $\$ 10$ per share. Then $A$ makes a two-for-one stock split. Assuming no other contemporaneous changes in $A$, after the split there would be 200 shares trading at $\$ 5$ per share. Although $A$ 's stock price would have dropped by half, $A$ 's shareholders would have twice as many shares, leaving their wealth unchanged. Alternatively, suppose Company $B$ has 100 shares trading at $\$ 10$ per share. Then $B$ pays a cash dividend of $\$ 5$ per share. Assuming no other contemporaneous changes in $B$, after the cash dividend the 100 shares in $B$ would trade at $\$ 5$ per share because there would be five dollars less per share worth of assets in the company. Yet the shareholders in $B$ would be unharmed by the decline in the stock price, as the decline would be offset by the payment of $\$ 5$ per share to those shareholders.

To avoid distortion from stock splits and dividends in our examination of stock prices over time, in the graphical and event study analyses that follow we use adjusted closing prices provided by CRSP that account for stock splits and dividends.

\section{B. Graphical Analysis}

On July 25, 2002, the day the Wall Street Journal broke the news of the Trustees' plan to sell, HSY closed at an unadjusted price of $\$ 78.30$, an increase of $\$ 15.80$ (more than 25 percent) from the prior day's closing price of $\$ 62.50$. On September 18, 2002, the first trading day after the Trustees publicly abandoned their sale plan at close to midnight on September 17, HSY closed at an unadjusted price of $\$ 65.00$, a decrease of $\$ 8.81$ (almost 12 percent) from the prior day's closing price of $\$ 73.81$.

While these price changes seem striking, it is possible that they are only coincidentally related to news of the sale and its abandonment. For example, the increase at the beginning of the sale window might reflect a preexisting upward trend in HSY, and the decline at the end of the sale window might be picking up the beginning of a downward trend. Another possibility is that these price movements, large though they may be, are the result of normal random variation in the price of HSY - that is, perhaps HSY is a volatile stock and this volatility manifested itself positively on July 25 and negatively on September 18. Lastly, these price changes could reflect general market movement common to all similar stocks on these days.

\footnotetext{
211 See http://www.crsp.com/.

212 See http://wrds.wharton.upenn.edu/. Historical HSY data is also available online at http://www.thehersheycompany.com/ir/pricelookup.asp\#.
} 
To rule out the possibility that the identified price movements are the result of existing trends or normal variation, we examine in Figure 1 the adjusted closing price of HSY during the sale window and for 50 trading days before and after the sale window. For a broader perspective, Figure A1 in Appendix A presents 500 trading days before and after the sale window, a practice we repeat for all the graphs in this section.

Figure 1:

HSY Price History

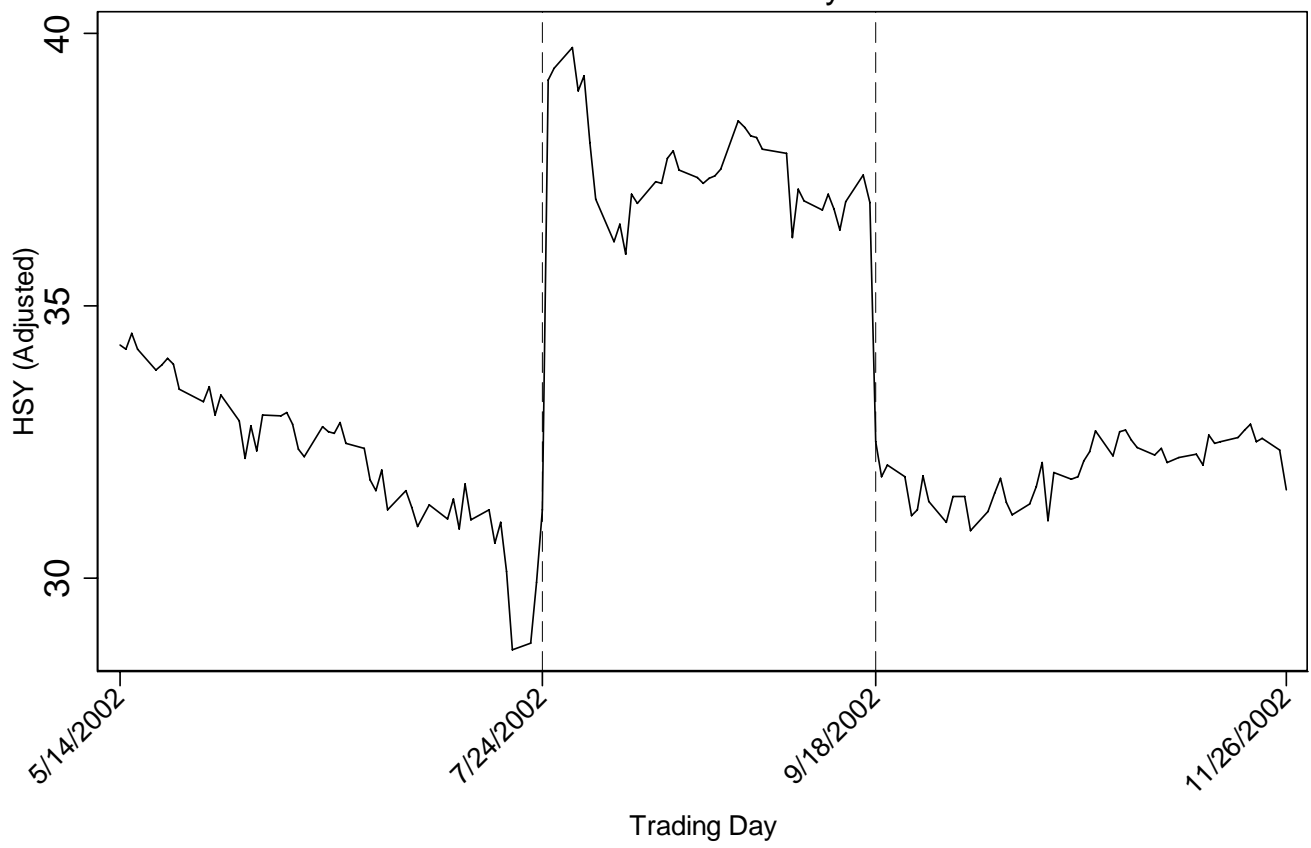

Figure 1 demonstrates that the price increase at the beginning and decrease at the end of the sale window were not artifacts of pre-existing trends. On the contrary, the price of HSY was trending downward before July 25, 2002 and began an upward trend not long after the sale was abandoned. ${ }^{213}$

Another possible explanation for the observed HSY price movements are coincidental changes in the chocolate market. To examine this possibility, Figure 2 (and Appendix Figure A2) adds contemporaneous price movements of three firms that compete with Hershey in the chocolate market: Cadbury-Schweppes (CSG), Tootsie Roll (TR), and Rocky Mountain Chocolate Factory (RMCF). ${ }^{214}$ These firms represent Hershey's principal NYSE-traded competitors with important chocolate

213 Appendix Figure A1 shows that the price of HSY returned to the sale window level about a year later, but per Appendix Figure A2, the subsequent upward trend in HSY resembles the upward trend experienced contemporaneously by other chocolate companies.

214 The RMCF stock price is plotted against the right hand axis in Figure 2 because its price range during the entire period is substantially lower than that of the other stocks. 
products (we consider the potential endogeneity problems with using competitors as a control in connection with our formal event study analysis below). ${ }^{215}$

Figure 2:

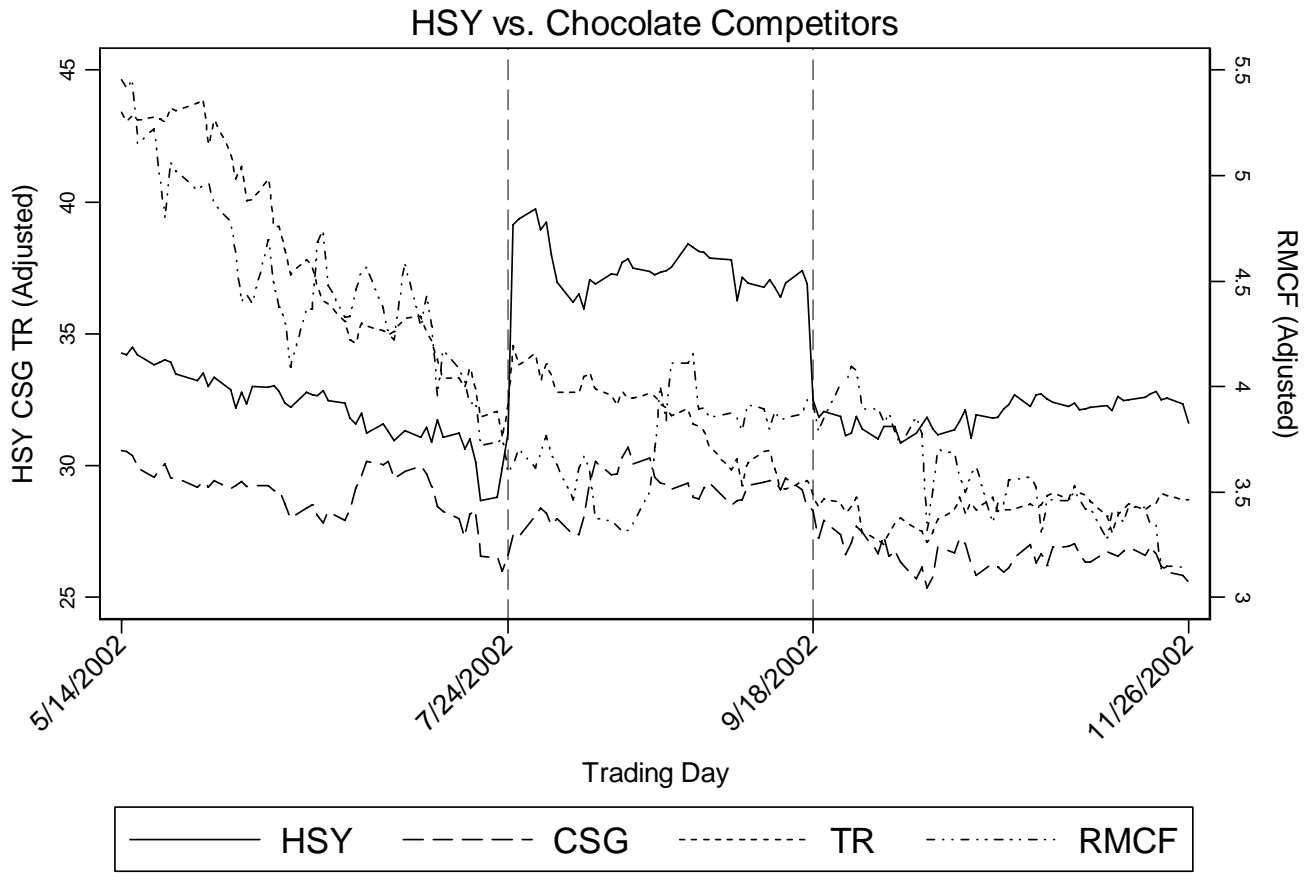

None of Hershey's chocolate market competitors experienced a comparable stock price jump on July 25, 2002, and none dropped as precipitously on September 18, 2002. Hence, we infer that the observed HSY price movements on those dates were not related to peculiar coincidental factors in Hershey's primary product market.

The Hershey Company's business is broader, however, than just chocolate. In 2002 Hershey also "manufacture[d] and/or markete[d] grocery products in the baking, beverage, peanut butter and toppings category."216 Thus, in Figure 3 (and Appendix Figure A3) we compare HSY price movements with those of ConAgra (CAG), Kraft Foods (KFT), and Tyson Foods (TSN), Hershey's principal food rivals. $^{217}$

215 We took our roster of Hershey's chocolate rivals from Google Finance (http://finance.google.com/finance? $\mathrm{q}=\mathrm{hsy}$ ) and Yahoo Finance (http://finance.yahoo.com/q/co?s=HSY), which list these firms as Hershey's primary publicly-traded competitors in the chocolate market. The other obvious contenders are Mars and Nestlé, but Mars is a privately held firm, so it has no public stock price data, and Nestlé is not traded on the New York Stock Exchange. While each of these competitors produces more than just chocolate, we categorize them as such because they do not reach the scale or scope of production of the firms that we categorize as food conglomerates in the analysis that follows in Figure 3.

216 The Hershey Company, Form 10-K, Annual Report for the fiscal year ended December 31, 2002, at 1 .

217 As in the chocolate market, we took our list of rival food firms from Google Finance and Yahoo Finance. See supra note _. These competitors are also noted in Hershey's Value-Line profile (Value- 
Figure 3:

HSY vs. Food Competitors

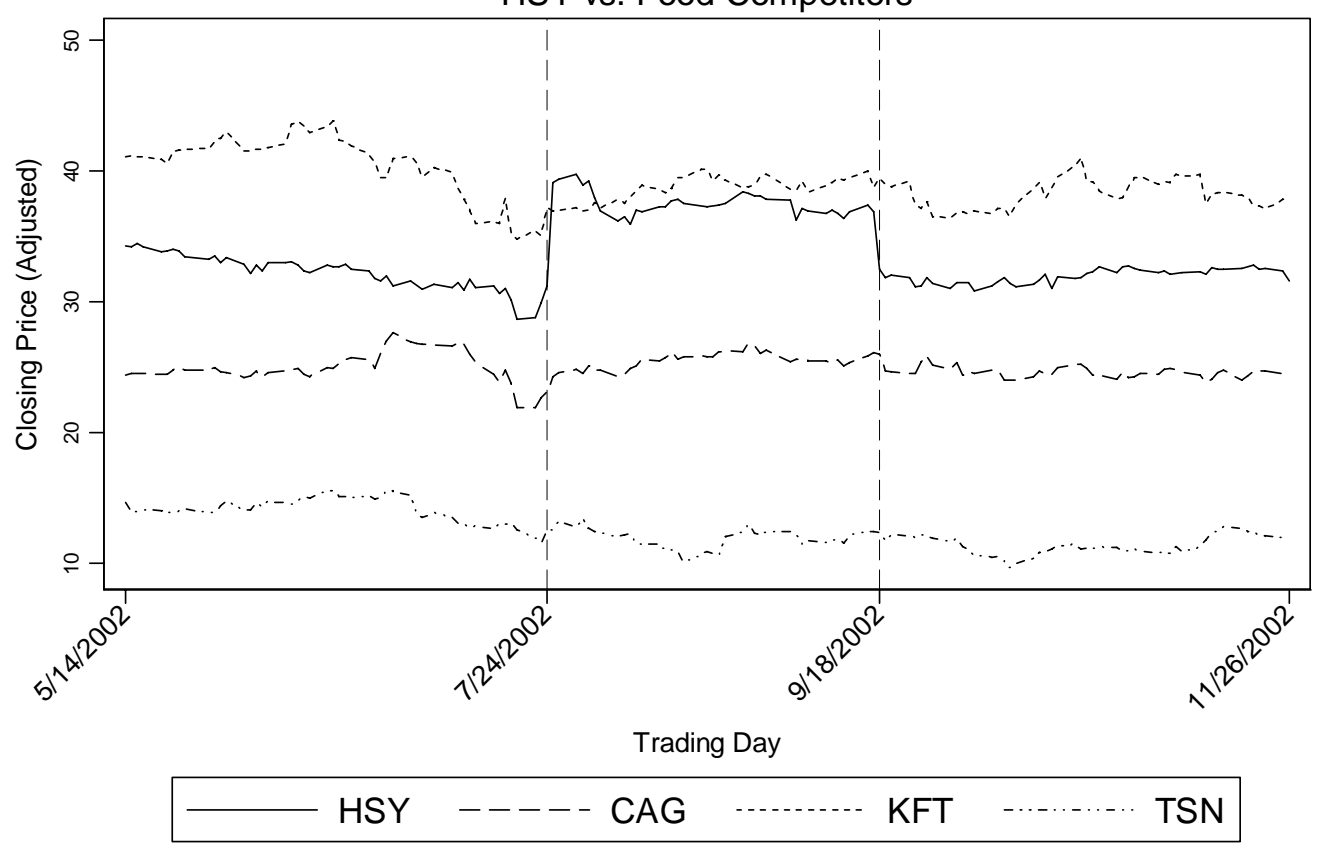

As in the chocolate market comparisons, we find no indication that the observed HSY price movements during the sale window were driven by trends in the food industry. For each of the comparison stocks, prices are largely flat throughout the sale window. Accordingly, we infer that the observed HSY price movements around the sale window were not related to peculiar coincidental factors in the food industry.

Finally, we examine whether general market trends might explain the observed HSY price dynamics. In Figure 4a (and Appendix Figure A4a), we plot HSY against the Standard and Poor's 500 market index (S\&P 500 plotted against the right-hand axis). In Figure 4b (and Appendix Figure A4b), we do the same for the Dow Jones Industrial Index (DJIA plotted against the right-hand axis). ${ }^{218}$

Line is silent on chocolate competitors). As before, some companies that would seem like good comparisons (e.g., Frito Lay) are not suitable because they are not publicly traded.

218 A similar picture would emerge if we plotted HSY against CRSP's value-weighted market index, which is often used in the finance literature as a representative market portfolio. 
Figure 4a:

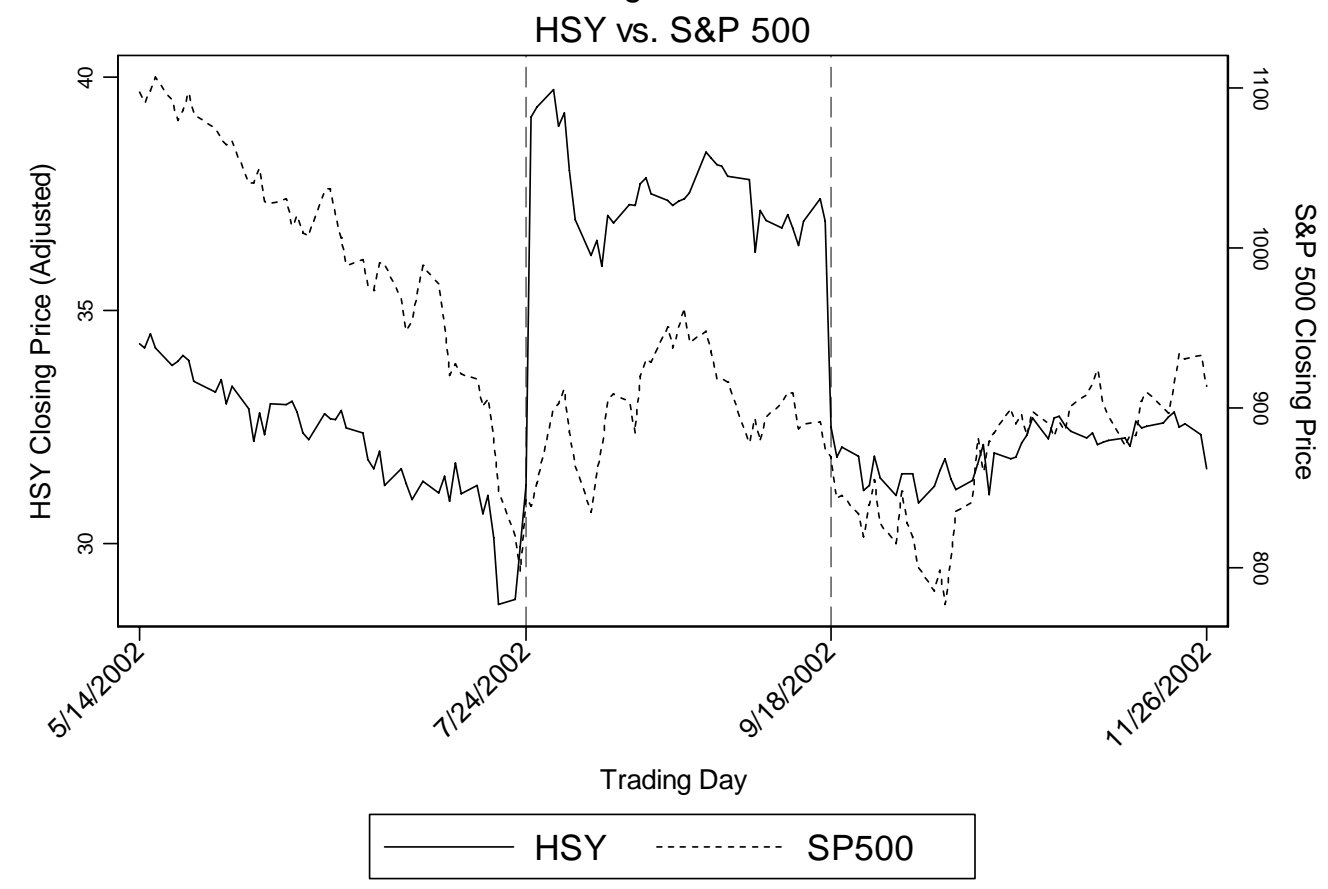

Figure 4b:

HSY vs. Dow Jones Industrial Average

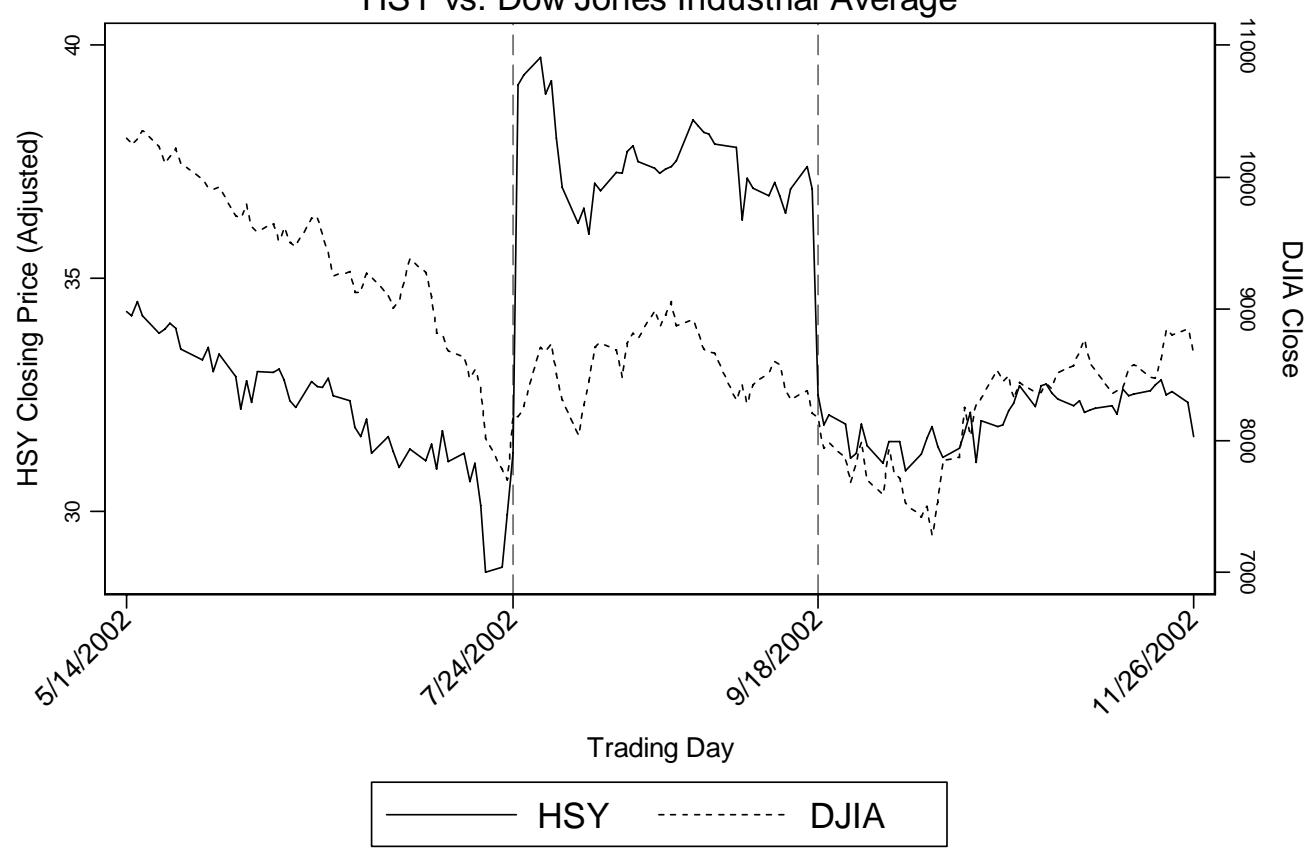

The differences between HSY's price dynamics and those of the market indexes are not as striking as in Figures 2 and 3. Both the S\&P 500 and the DJIA experienced price appreciation toward the beginning of the sale window and depreciation toward the end of the sale window. These market movements do not correspond 
precisely with that of HSY, however, as the market indexes began their rise after July 25, 2002 and started their downward trend before September 18, 2002. Further, in neither case is the relative price change as great as that experienced by HSY. Nonetheless, the observed comovement of the market indexes and HSY casts some doubt on the causal relationship between the Trust's proposed sale and the movement of Hershey's stock price. ${ }^{219}$ To sort these possibilities, in the next section we employ a more formal event study econometric analysis that separates the effect of sale-related news from general market trends.

\section{Event Study Analysis}

\section{Introduction}

The comparisons of HSY and the market indexes give us pause in attributing the HSY price dynamics during the sale window to sale-related news. To untangle the effect of general market trends from sale-related news, it is necessary to net out market-related variations in Hershey's stock price. The event study methodology, which is "well-accepted and extensively used in finance," 220 provides a reliable means to that end. As Sanjai Bhagat and Roberta Romano explain in their recent survey of empirical analysis of corporate law, "Event studies apply conventional econometric techniques to measure the effect of specific events, such as actions by firms, legislatures, and government agencies, on the stock price of affected firms. Their advantage for policy analysis is that they provide an anchor for determining value, which eliminates reliance on ad hoc judgments about the impact of specific events or policies on stock prices." 221

Two ideas underpin the market model event study methodology that we employ below. ${ }^{222}$ The first is the efficient capital markets hypothesis (ECMH). In its semi-strong version, the ECMH posits that the price of a publicly-traded security reflects all public information on the present value of the future cash flow associated with ownership of the security. Hence, in a semi-strong efficient market, only nonpublic information such as an unanticipated event will affect securities prices, and traders cannot exploit publicly-available information for gain. The prevailing view

219 Although Hershey is included in the S\&P 500, it accounts for less than 0.2 percent of the S\&P 500 index, and the movement of the DJIA, which does not include HSY, follows the same general pattern.

220 Bhagat \& Romano, supra note _, at 3. Bhagat and Romano continue, "Event study results have been used in several hundred scholarly articles in leading academic finance journals to analyze corporate finance issues." Id.

221 Id. at 5.

222 For a more detailed discussion of event study methodology, see id., particularly Part 2 (“A Guide to Event Studies"), on which our discussion draws. For a more technical discussion, see John Y. Campbell, Andrew W. Lo, \& A. Craig MacKinlay The Econometrics of Financial Markets ch. 4 (1997); S.P. Kothari \& Jerold B. Warner, Econometrics of Event Studies, in B.E. Eckbo, ed., The Handbook of Corporate Finance: Empirical Corporate Finance (forthcoming ___), available at http://mba.tuck.dartmouth.edu/pages/faculty/espen.eckbo/PDFs/Handbookpdf/CH1-EventStudies.pdf. 
among financial economists is that the domestic stock market is semi-strong efficient in the sense that is important for event study analysis. ${ }^{223}$

The second idea is that in the short run the relationship between an individual security and the market as a whole is relatively stable. Thus it is possible to assess in retrospect whether on a given day a particular stock experienced an "abnormal" price movement, meaning a change in price that deviates in a significant way from the stock's typical relationship with the market as a whole. Importantly, we do not claim that it is possible to predict a stock's future price movements based on past performance. Rather, the claim is that on Tuesday we can judge whether a particular stock's price movement on Monday was "normal" or "abnormal" for that stock in relation to the known movement of the market as a whole on that same Monday.

Taken together, these two ideas imply that it is possible to assess empirically the effect of an unanticipated event on a company's stock price. Consider a grossly simplified, stylized example. Suppose that for 100 days the price of Company A's stock increased or decreased in perfect concert with the market as a whole. Then on day $101 A$ 's managers announce a new business plan and the stock goes up 12 percent. If the market as a whole went up 5 percent on that day, so that a "normal" movement of $A$ 's stock would have been a 5 percent increase, we could attribute the "abnormal" difference of 7 percent to the unanticipated news of the new business plan.

\section{HSY Event Study}

Implementation of the foregoing intuitions in a market model event study may be broken down into five steps: ${ }^{224}$ (1) define the event and identify the date or dates on which information of the event became public; (2) measure the affected security's actual return on the dates of interest; (3) estimate the security's expected return on the dates of interest using historical data on the relationship of the affected security to the market as a whole; (4) compute the abnormal return by subtracting the expected return from the actual return; and (5) assesses the statistical significance of the abnormal return. Once these five steps are completed, it is possible to evaluate the economic significance, if any, of the abnormal return on the dates of interest. We take each step in turn.

(1) Our event is the aborted sale of the Trust's controlling interest in the Hershey Company. Hence, we focus on the 38 trading day sale window that began on July 25, 2002 and ended on September 18, 2002. Within this window, we are particularly interested in (a) July 25, 2002, the day that news of the sale was broken by the Wall Street Journal; (b) September 4, 2002, the day that the trial court issued an

223 Put more directly, the debate over the validity of the ECMH concerns matters that do "not invalidate the event study methodology." Bhagat \& Romano, supra note _, at 4 n.1.

${ }^{224}$ Our five-step statement of the mechanics of an event study draws on the four-step statement in Bhagat \& Romano, supra note _ , at 5-11, except that for expositional clarity we have broken their step four into two separate steps. 
injunction against the sale; and (c) September 18, 2002, the first trading day after the trustees abandoned the sale late in the evening on September 17.225

(a) The impact of the July 25 sale announcement tests our hypotheses regarding agency costs in charitable trust governance and the comparative virtues of a controlling shareholder versus the market for corporate control in minimizing agency costs in corporate governance. For the reasons explained earlier, we predict a large, positive abnormal return on that date.

(b) The impact of the September 4 injunction provides a test of the welfare effects of the attorney general's intervention. The September 4 injunction also provides a robustness check on our analysis of the July 25 sale announcement. Because the injunction reduced the probability of a sale, but did not extinguish the possibility of one, we predict a negative abnormal return that is smaller in absolute magnitude than July 25's abnormal return.

(c) The impact of the trustee's September 18 abandonment of the sale provides a second test of our agency cost hypotheses, both as a robustness check on our finding for July 25 and to exclude the alternative hypothesis that the fact of the sale announcement itself supplied new information about the Company. We predict a negative abnormal return that, given the prior injunction, falls in absolute magnitude between that of the September 4 and July 25 dates. ${ }^{226}$

Table 2 summarizes the key dates of interest and our predicted impacts of the events of those dates.

\section{Table 2:}

Key Events and Predicted Impacts

\begin{tabular}{rcc}
\hline \multicolumn{1}{c}{ Date } & Event & Predicted Impact \\
\hline $7 / 25 / 2002$ & Sale Announced & Positive \\
9/4/2002 & Sale Enjoined & Negative \\
9/18/2002 & Sale Abandoned & Negative \\
\hline \hline
\end{tabular}

225 We do not test the effect of the subsequent amendment to the Pennsylvania prudent investor rule, see text accompanying supra notes 157-161, for two reasons. First, prior to the amendment the trustees committed in writing not to sell the Company without first notifying the attorney general's office, and the trial court included this requirement in its October 16 order dissolving the preliminary injunction. Second, it is hard to isolate a clean event date for legislative enactments without introducing bias. See Bhagat \& Romano, supra note _, at 7. Here the attorney general made various public announcements about supporting the legislation, which then passed each house of the Pennsylvania legislature on different dates, and then was signed by governor on still another date.

226 In theory, if there were no other indications during the sale window that the trustees might abandon the sale, we would have expected the September 18 abnormal return to equal the July 25 abnormal return, except oppositely signed. However, the attorney general's actions during the window, as well as those of the courts and members of the local community, decreased the probability of a sale. Inasmuch as this expectation would have been capitalized (probabilistically) into the HSY price, we expect a large negative abnormal return on September 18, but one that is smaller in magnitude to that observed on July 25 . 
(2) The next step, which is relatively simple, is to measure the actual return of HSY during the sale window. Actual return is routinely calculated as the price of the stock at time $t+1$ minus the price at time $t$ divided by the price at time $t$. Using adjusted daily closing prices, in the third column of Table 3 (below) we present HSY's actual return for each trading day within the sale window.

(3) The third step, estimating the security's expected return, is more complicated. We use a statistical market model that posits that HSY's expected return may be estimated as a linear function of the return of the market as a whole. ${ }^{227}$ This relationship is expressed as follows:

$$
E\left(H S Y_{t}\right)=\lambda_{H S Y}+\phi_{H S Y} \cdot \text { Market }_{t}
$$

Where $E\left(H S Y_{t}\right)$ is the expected return for HSY during time period $t, \lambda_{H S Y}$ is an HSY-specific constant, $\phi_{H S Y}$ is an HSY-specific coefficient (i.e., a measure of how the HSY return has varied historically in relationship to the market return), and Market $_{t}$ is the market return over timeframe $t$. Hence, to compute the expected return for HSY during the sale window, we multiply the market return during the window by $\phi_{H S Y}$ and then add $\lambda_{H S Y}$.

To estimate $\lambda_{H S Y}$ and $\phi_{H S Y}$, we perform an ordinary least squares regression on actual HSY returns for some period before the sale window (this period is known as the "estimation period") using the returns for a market portfolio as a predictor variable. For our market portfolio, we use the S\&P 500. ${ }^{228}$ For our estimation period, we use 100 trading days prior to the event (i.e., the sale window), which is a common estimation period in event studies that use a statistical model. ${ }^{229}$ In the fourth column of Table 3 (below), we present our estimated expected return for HSY during each of the trading days during the sale window. In unreported regressions we also used an estimation period of 200 days before the sale window with similar results.

A potential criticism of using data prior to the sale window to estimate expected returns during the sale window is that the sale window might have coincided

\footnotetext{
227 There are three notable alternatives to the statistical market model. Two are economic models (the Capital Asset Pricing Model and the Arbitrage Pricing Theory) and the third is another statistical model (the constant expected returns model). In general, the economic models introduce additional complexity without an offsetting improvement in the estimation. See Campbell, Ho, \& MacKinlay, supra note _, at 153-157; Bhagat \& Romano, supra note _, at 7-9. Moreover, unlike the market model, which accounts for broad market trends, the constant expected returns model looks only to the historical price movement of the security at issue. The choice of expected return model did not affect the results, however, as our findings were largely unchanged when we used a constant expected returns model or one of the economic models.

228 The principal alternatives to the S\&P 500 are the DJIA and the CRSP index. The results were largely unchanged, however, when we used these alternatives.

229 See Bhagat \& Romano, supra note _, at 9.
} 
with a structural change in the relationship between HSY and the market portfolio. If so, the historical relationship between HSY returns and the market return will no longer hold. As a check on this possibility, we also computed expected returns for HSY during the sale window using estimation periods of 100 days after the sale window, 200 days after the sale window, and a pooled model that included 100 days before and 100 days after the sale window. Each of these alternate approaches yielded results similar to the 100-days-prior results that we report below.

Another potential concern is that during the 100 trading days prior to the sale window, Hershey factory workers went on strike (the strike lasted from April 26, 2002 to June 8, 2002). To determine whether the strike introduced bias in our analysis, we investigated a 100 day estimation period that excluded the strike period as well as an estimation model that included a control variable for days during the strike. In both cases our results were little changed. This is consistent with Hershey's own evaluation of the effect of the strike. In its quarterly filing with the SEC for the period that included the strike, the Company reported that "The work stoppage did not have a material impact on the Corporation's results of operations for the second quarter." 230

(4) The next step is computing the abnormal return for HSY during each trading day in the sale window. The abnormal return is computed by subtracting the expected return from the actual return. The fifth column of Table 3 presents our abnormal return estimates.

(5) The final step is to assess the statistical significance of the abnormal return. By statistical significance we mean a measure of the likelihood that the observed abnormal return reflects random variation rather than the influence of the event under study. A typical significance threshold is 5 percent, with 2.5 percent of abnormal returns falling below a negative critical value and 2.5 percent of abnormal returns falling above a positive critical value that is symmetric to the negative critical value. That is, if the HSY return were to follow its historical relationship with the market return and not be affected by an unanticipated occurrence, then on any given day its observed abnormal return would fall between our positive and negative critical values 95 percent of the time. Accordingly, if a given day's abnormal return falls outside of these critical values, we may infer a 95 percent likelihood that something peculiar on that day caused the HSY return to deviate from its normal relationship with the market return. By contrast, the alternative possibility that the day in question experienced an abnormal return owing to random variation would be only 5 percent likely. Critical values may also be computed for significance thresholds other than 5 percent, such as 1 percent or 0.1 percent (implying 99\% and 99.9\% likelihood respectively).

In the sixth column of Table 3 we present the standardized abnormal return for HSY during each day in the sale window. The standardized abnormal return is

230 The Hershey Company, Form 10-Q, Quarterly Report for the Quarter ended June 30, 2002, at 15 (filed Aug. 7, 2002). 
the ratio between the abnormal return and the standard deviation of the abnormal returns during the estimation period. ${ }^{231}$ For standardized abnormal returns that exceed 1.96 or are less than -1.96 , there is less than a 5 percent chance that the observed abnormal return reflects random variation. That percentage falls to 1 percent for standardized abnormal returns above 2.575 or below -2.575 , and to 0.1 percent for those above 3.277 or below $-3.277 .{ }^{232}$ In Table 3 and the other tables that follow, we denote statistical significance at the 5,1 , and 0.1 percent levels with *, **, and $* * *$ notations respectively.

Table 3

HSY Returns During Sale Window

\begin{tabular}{|c|c|c|c|c|c|}
\hline Date & Event & Actual & Expected & Abnormal & $\begin{array}{l}\text { Standardized } \\
\text { Abnormal }\end{array}$ \\
\hline $7 / 25 / 2002$ & $\begin{array}{l}\text { Sale } \\
\text { Announced }\end{array}$ & 0.253 & -0.002 & 0.255 & $21.250^{\star \star \star \star}$ \\
\hline $7 / 26 / 2002$ & & 0.005 & 0.006 & -0.000 & -0.000 \\
\hline 7/29/2002 & & 0.010 & 0.018 & -0.008 & -0.667 \\
\hline $7 / 30 / 2002$ & & -0.020 & 0.001 & -0.021 & -1.750 \\
\hline $7 / 31 / 2002$ & & 0.007 & 0.003 & 0.004 & 0.333 \\
\hline 8/1/2002 & & -0.031 & -0.010 & -0.021 & -1.750 \\
\hline $8 / 2 / 2002$ & & -0.028 & -0.008 & -0.019 & -1.583 \\
\hline $8 / 5 / 2002$ & & -0.021 & -0.012 & -0.009 & -0.750 \\
\hline 8/6/2002 & & 0.009 & 0.010 & -0.001 & -0.083 \\
\hline 8/7/2002 & & -0.015 & 0.007 & -0.022 & -1.833 \\
\hline 8/8/2002 & & 0.031 & 0.011 & 0.020 & 1.667 \\
\hline 8/9/2002 & & -0.004 & 0.001 & -0.005 & -0.417 \\
\hline 8/12/2002 & & 0.011 & -0.002 & 0.013 & 1.083 \\
\hline 8/13/2002 & & -0.001 & -0.008 & 0.007 & 0.583 \\
\hline $8 / 14 / 2002$ & & 0.012 & 0.013 & -0.001 & -0.083 \\
\hline $8 / 15 / 2002$ & & -0.004 & 0.004 & -0.000 & -0.000 \\
\hline 8/16/2002 & & -0.009 & -0.001 & -0.008 & -0.667 \\
\hline 8/19/2002 & & -0.004 & 0.008 & -0.012 & -1.000 \\
\hline 8/20/2002 & & -0.003 & -0.005 & 0.002 & 0.167 \\
\hline $8 / 21 / 2002$ & & 0.002 & 0.004 & -0.002 & -0.167 \\
\hline $8 / 22 / 2002$ & & 0.001 & 0.005 & -0.003 & -0.250 \\
\hline 8/23/2002 & & 0.003 & -0.008 & 0.011 & 0.917 \\
\hline 8/26/2002 & & 0.024 & 0.002 & 0.021 & 1.750 \\
\hline $8 / 27 / 2002$ & & -0.003 & -0.005 & 0.002 & 0.167 \\
\hline 8/28/2002 & & -0.004 & -0.006 & -0.003 & -0.250 \\
\hline 8/29/2002 & & -0.001 & -0.000 & -0.001 & -0.083 \\
\hline 8/30/2002 & & -0.006 & -0.001 & -0.005 & -0.417 \\
\hline
\end{tabular}

231 There is concern in the event study literature that the standard deviation of abnormal returns during the estimation period is not a useful measure of variation because of increased volatility around potentially important events. See, e.g., Bhagat \& Romano, supra note _, at 10. Hence, we examined a number of alternative measures of variation including the standard deviation of abnormal returns during the sale window. We also estimated expected returns using a GARCH model that uses a time series technique that allows for a more general variance structure. See James D. Hamilton, Time Series Analysis 665-671 (1994). Our results are not affected by these different measures of variation.

232 These significance levels assume that the abnormal returns will be distributed normally with a mean of zero. But in a one-firm event study the abnormal returns might not be well approximated by the normal distribution. We address this concern in Part III.C.4 and in Appendix C. 


\begin{tabular}{llllll}
$9 / 3 / 2002$ & & -0.002 & -0.014 & 0.012 & 1.000 \\
$9 / 4 / 2002$ & Sale & -0.041 & 0.006 & -0.047 & $-3.917^{\star \star *}$ \\
& Enjoined & & & & \\
$9 / 5 / 2002$ & & 0.025 & -0.006 & 0.030 & $2.500^{*}$ \\
$9 / 6 / 2002$ & & -0.006 & 0.005 & -0.012 & -1.000 \\
$9 / 9 / 2002$ & & -0.004 & 0.003 & -0.008 & -0.667 \\
$9 / 10 / 2002$ & & 0.008 & 0.002 & 0.005 & 0.417 \\
$9 / 11 / 2002$ & & -0.007 & -0.000 & -0.007 & -0.583 \\
$9 / 12 / 2002$ & & -0.010 & -0.009 & -0.002 & -0.167 \\
$9 / 13 / 2002$ & & 0.014 & 0.001 & 0.013 & 1.083 \\
$9 / 16 / 2002$ & & 0.013 & 0.000 & 0.013 & 1.083 \\
$9 / 17 / 2002$ & & -0.013 & -0.007 & -0.006 & -0.500 \\
$9 / 18 / 2002$ & Sale & -0.119 & -0.002 & -0.118 & $-9.833^{\star \star *}$ \\
& Abandoned & & & & \\
\hline
\end{tabular}

Note: ${ }^{\star \star \star} p<0.001 ;{ }^{* \star} p<0.01 ;{ }^{\star} p<0.05$ (i.e., abnormal return is statistically significant at the $0.1 \%, 1 \%$, and $5 \%$ levels respectively).

Our primary date of interest is July 25, 2002, the day in which the Wall Street Journal broke the news of the trustees' plan to sell. As we have seen, on July 25 the price of HSY jumped to an unadjusted closing price of $\$ 78.30$ from the prior day's closing price of $\$ 62.50$. This increase translates to an adjusted actual return of 0.253 on a day that, ${ }^{233}$ given the movement of the market as a whole, HSY would have been expected to experience a return of -0.002. So the abnormal return for HSY on July 25 was 0.255 , which translates to a standardized abnormal return of 21.25. Accordingly, HSY experienced a large, abnormal positive return on the date news of the trustees' plan to sell became public, and it is extremely unlikely that this finding reflects random variation instead of news of the sale plan (the finding is statistically significant at less than the 0.1 percent level). Indeed, excluding September 4 and September 18 (the dates on which the sale was enjoined and abandoned), the standardized abnormal return for July 25 was 8.5 times larger than the second largest and more than 12 times larger than the third largest standardized abnormal returns for any other day in the sale window.

Our second date of interest is September 4, 2002, the day that the trial court enjoined the sale. HSY dropped to $\$ 72.51$ from the prior day's closing price of $\$ 75.60$, which translates to an adjusted actual return of -0.041. The expected return for HSY was 0.006. Hence, on September $4 \mathrm{HSY}$ experienced an abnormal return of -0.047. This result is statistically significant at less than the 0.1 percent level (the standardized abnormal return was -3.917).

Interestingly, the next day HSY experienced a positive abnormal return of .03 that is statistically significant at the 5 percent level. Although we did not hypothesize that there would be a large abnormal return on that day, this finding could suggest a number of possibilities. First, perhaps the September 5 return represents one of the rare instances where the abnormal return falls outside of the critical values wholly by chance.

233 Recall that in the graphs and econometric analyses we use adjusted closing prices, not actual closing prices, hence we report actual return in relation to the adjusted price data. 
Second, it is possible the market over-reacted to the court's decision, believing that it represented a larger setback to the trustees than it actually was. ${ }^{234}$ Perhaps investors believed that the trustees would abandon the sale after the issuance of the injunction, but re-evaluated those beliefs when the trustees appealed immediately after the court decision. In their September 5 coverage of the trial court's decision, both the Wall Street Journal and The New York Times stated that "legal experts" predicted that the injunction would be lifted on appeal. ${ }^{235}$

In all events, the sum of the abnormal returns for September 4 and 5 is negative and hence signed as we predicted for September 4. These results, moreover, undermine the trial court's conclusion that issuing the injunction would not "cause significant fluctuations" in the Company's stock. ${ }^{236}$

Our third date of interest is September 18, 2002, the first trading day after the trustees abandoned the sale close to midnight on September 17. On September 18 , HSY dropped to $\$ 65.00$ from the prior day's closing price of $\$ 73.81$, which translates to an adjusted actual return of -0.119. The expected return for HSY was 0.002. Thus, on September 18 HSY experienced a negative abnormal return of 0.118. ${ }^{237}$ This result, which is statistically significant at less than the 0.1 percent level (the standardized abnormal return was -9.833), belies the attorney general's argument in his appellate brief that "nothing suggests that the stock will be priced differently even if a sale does not occur." 238

Accordingly, for all three principal dates of interest, we find highly statistically significant abnormal returns in the direction (that is, positive or negative) predicted by our agency cost hypotheses. The magnitude of the abnormal returns associated with the sale announcement and then the sale abandonment are striking: 25.5 and -11.8 percent respectively. Apart from the three primary dates of interest and the day after the injunction, there are no other dates during the sale window with abnormal returns that are significant at the 5 percent level or better. Further, the five abnormal returns that are significant at the 10 percent level (critical value $\pm 1.65)$ are signed as one would expect in view of the events on and around those days. $^{239}$

234 There is an ongoing debate in the finance literature about whether investors systematically overreact to bad news and if so whether sophisticated investors can profit from this tendency by engaging in a contrary investment strategy (e.g., purchasing shares in firms that depreciate after bad news). The empirical evidence of this phenomenon is mixed. For one study finding such an effect, see H. Nejat Seyhun, Overreaction or Fundamentals: Some Lessons from Insiders' Response to the Market Crash of 1987, 45 J. Fin. 1363 (1990).

235 See text accompanying supra notes _.

236 See supra notes _ and text accompanying.

237 The discrepancy between the reported abnormal return in column 5 and the sum of the reported expected and actual returns in columns 3 and 4 (i.e., $-0.119--0.002=-0.118$ ) is the result of rounding.

238 See supra note _ and text accompanying.

239 On July 30 and August 1 both, as local opposition to the sale began to organize, HSY experienced negative abnormal returns of 2.1 percent. On August 7, while the trustees met to consider Fischer's proposed alternative modes of diversification, HSY experienced a negative abnormal return of 
To summarize and give greater context to our findings, in Figure 5a we present Hershey's cumulative abnormal returns (i.e., the sum of the abnormal returns; "CAR") for the sale window plus 25 trading days before and after the sale window. ${ }^{240}$

Figure 5a:

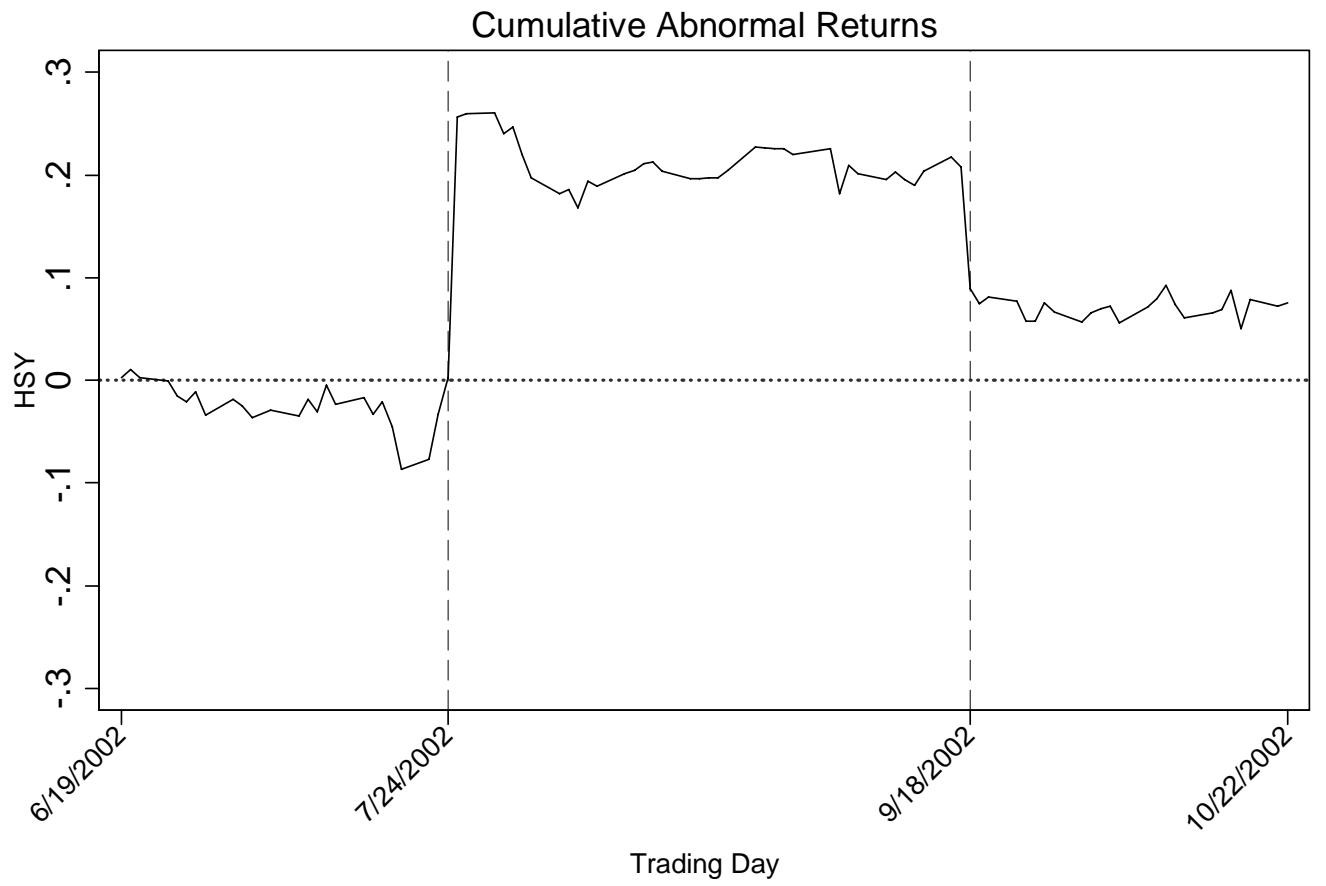

Figure 5a demonstrates that HSY's CAR during the sale window were neither the continuation of some pre-existing trend nor the start of a new trend. Consistent with our agency cost hypotheses, the company was simply more valuable to investors during the period when the market expected the trustees to sell the Trust's controlling interest.

Interestingly, the CAR for Hershey remains above zero for some time after the end of the sale window. Assuming this finding is significant, ${ }^{241}$ the data do not

2.2 percent. That evening, after the stock market closed, the trustees announced that they would press ahead with the sale. The next day, August 8, HSY experienced a positive abnormal return of 2 percent. Finally, on August 26, the day the trustees filed their papers in opposition to the attorney general's petition for a preliminary injunction, HSY experienced a positive abnormal return of 2.1 percent.

240 Because in this Figure (and in Figures $5 \mathrm{~b}$ and $5 \mathrm{c}$ below) we include abnormal returns for 25 trading days before the sale window, in our expected returns regression we use as our estimation period the 100 trading days before the first trading day plotted.

241 Although the CAR over the event window is statistically significant $(t=2.59)$, when calculated from the beginning of the event window through the end point in the graph above (October 22, 2002), the CAR drops below the threshold for statistical significance $(\mathrm{t}=0.54)$. Thus, at some point during the month after the Hershey sale was abandoned, cumulative abnormal returns dropped to the point where they were no longer statistically distinguishable from zero. 
allow us to isolate an explanation, except that we can say that the increased Hershey CAR is probably not an artifact of secular trends in the chocolate or food industries, as infra Figures 5b and 5c indicate that Hershey's competitors do not likewise exhibit systematically higher CARs after the sale window. ${ }^{242}$ Early empirical work on failed mergers suggests that target firms often exhibit increased CARs after a failed merger. ${ }^{243}$ Later work, however, discovered that these gains tend to dissipate over a longer time horizon. ${ }^{244}$ The literature suggests two possible explanations for these results: (1) a "kick-in-the-pants" idea, in which a target firm's management is inspired to implement a more efficient business strategy after the failed takeover attempt, and (2) the market's expectation that another acquiring firm will attempt a takeover in the near future. ${ }^{245}$ We conjecture that explanation (1) pertains here, but we can neither establish nor reject it empirically.

\section{Competitor-Based Controls}

As a check to rule out the possibility that factors unrelated to the Hershey sale might explain the observed abnormal returns on the three primary days of interest, we performed a similar abnormal return analysis for Hershey's principal NYSE-traded competitors identified in the earlier graphical analysis. ${ }^{246}$ The results are presented in Table 4.

Table 4

Standardized Abnormal Returns-HSY and Competitors

\begin{tabular}{lllllllll}
\hline \hline Date & Event & HSY & CSG & TR & RMCF & CAG & KFT & TSN \\
\hline $7 / 25 / 2002$ & $\begin{array}{l}\text { Sale } \\
\text { Announced }\end{array}$ & $21.25^{\star \star *}$ & $2.62^{\star *}$ & $6.17^{\star \star \star}$ & 0.30 & $3.25^{\star \star}$ & -0.43 & 0.35 \\
& & & & & & &
\end{tabular}

242 That Hershey's competitors did not likewise experience increased CARs runs counter to the empirical regularity that rival firms' returns tend to go up after a firm in the industry is involved in a takeover activity. See Espen Eckbo, Horizontal Mergers, Collusion, and Stockholder Wealth, 11 J. Fin. Econ. 241, 257-259 (1983); Espen Eckbo, Mergers and the Market Concentration Doctrine: Evidence from the Capital Market, 58 J. of Bus. 325, 338 (1985). Although early studies did not find evidence consistent with any particular causal mechanism for this phenomenon, more recent work suggests that the increase in competitors' CARs stems from an expectation that other firms in the industry will also become takeover targets. See Moon H. Song and Ralph A. Walkling, Abnormal Returns to Rivals of Acquisition Targets: A Test of the Acquisition Probability Hypothesis, 55 J. Fin. Econ. 143, 170 (2000). Our finding that Hershey's rivals did not experience the typical increase in returns is consistent with this explanation, as the Hershey takeover activity was prompted by the trustees, not by an external buyer that, after failing to acquire the Hershey Company, might be expected to try to takeover one of Hershey's rivals.

243 See, e.g., Peter Dodd and Richard Ruback, Tender Offers and Stockholder Returns: An Empirical Analysis, 5 J. Fin. Econ. 351, 370 (1977); Michael Bradley, Interfirm Tender Offers and the Market for Corporate Control, 53 J. Bus. 345, 368-372 (1980).

244 See, e.g., Michael Bradley, Anand Desai, \& E. Han Kim, The Rationale Behind Interfirm Tender Offers, 11 J. Fin. Econ. 183, 194 (1983); Frank J. Fabozzi, Michael G. Ferri, T. Dessa Fabozzi, \& Julia Tucker, A Note on Unsuccessful Tender Offers and Stockholder Returns, 43 J. Fin. 1275, 1282 (1988).

245 See, J. Fred Weston, Juan A. Siu, and Brian A. Johnson, Takeovers, Restructuring, and Corporate Governance 144 (3d ed. 2001).

246 See supra notes _ and _ and text accompanying. 


$\begin{array}{lllllllll}\text { 9/4/2002 } & \text { Sale } & -3.92^{\star * \star} & 0.38 & 0.75 & -0.23 & 0.25 & -0.14 & -1.43 \\ & \text { Enjoined } & & & & & & & \\ 9 / 5 / 2002 & & 2.50^{*} & 0.39 & -2.37^{*} & -0.20 & 0.52 & 0.70 & 2.41^{*} \\ 9 / 18 / 2002 & \text { Sale } & -9.83^{\star * \star} & -0.23 & 1.33 & -0.09 & -0.19 & 0.76 & -0.30 \\ & \text { Abandoned } & & & & & & & \end{array}$

Note: ${ }^{\star \star \star} p<0.001 ;{ }^{* \star} p<0.01 ;{ }^{\star} p<0.05$ (i.e., abnormal return is statistically significant at the $0.1 \%, 1 \%$, and $5 \%$ levels respectively).

None of Hershey's competitors experienced an unusually large abnormal return on September 4 or September 18, and there is no consistent relationship between the abnormal returns of Hershey and its competitors on September 5. However, on July 25, the day the Hershey sale was announced, three of Hershey's competitors (CSG, TR, and CAG) experienced large, positive abnormal returns that were unlikely to have come about by chance. These results are amenable to at least two different interpretations.

One possible interpretation of Table 4 is that news of the sale positively affected not only Hershey's value, but also the value of some of its competitors. There is, in other words, a potential endogeneity problem in using HSY's competitors as controls because changes in HSY might affect the value of the competitors, and vice versa. For example, perhaps Hershey's stock price was depressed because the Company was overproducing above the efficient level to protect the jobs of its employees. With new management, the Company might reduce its production to the profitmaximizing level, thereby improving its value. A reduction in Hershey's output would also benefit at least some of its competitors, as they would have less competition from Hershey for individual sales. ${ }^{247}$ A further endogeneity problem arises from the possibility that one of these competitors might bid on HSY.

Although the foregoing interpretations are consistent with our agency cost hypotheses (particularly the overproduction story), we do not find them persuasive. If CSG, TR, and CAG experienced positive abnormal positive returns on July 25 because the market anticipated a decline in output by Hershey, then those companies should have experienced negative abnormal returns on September 18, when the sale was cancelled, and possibly also on September 4, when the sale was enjoined. But only two of those six abnormal returns were negative, both were relatively small, and neither was statistically significant. Unlike HSY, in other words, CSG, TR, and CAG did not experience parallel negative abnormal returns on news that HSY would

247 The scenario sketched above would be similar to the result identified in Brian Knight, Are Policy Platforms Capitalized into Equity Prices? Evidence from the Bush/Gore 2000 Presidential Election, 90 J. Pub. Econ. 751 (2006). Knight examined the relationship between daily market prices for firms that compete with Microsoft and the probability of a Bush victory in the 2000 presidential election using the Iowa Electronic Markets for the Bush victory probabilities. He found that when the probability of a Bush win was high, the share prices for Microsoft's competitors declined significantly, presumably reflecting a market expectation of more favorable treatment for Microsoft in the pending antitrust litigation under a Bush administration than under a Gore administration. But see George Bittlingmayer \& Thomas Hazlett, Dos Kapital: Has Antitrust Action Against Microsoft Created Value in the Computer Industry?, 55 J. Fin. Econ. 329 (2000) (finding that antitrust actions unfavorable to Microsoft hurt the entire computer industry, and that actions favorable to Microsoft helped). 
not be sold. The same evidence militates against the possibility that investors were pricing the possibility of acquiring HSY into the competitors' share prices.

The alternative and in our view more likely interpretation of Table 4 is that there were other market peculiarities on July 25, 2002. For example, there might have been an exogenous shock, unrelated to the news of the sale, which affected the value of some chocolate and food companies. On this account, the abnormal return experienced by Hershey on July 25 might in part reflect the influence of the exogenous shock. We think that this is a more plausible interpretation as it is consistent with there being no statistically significant abnormal returns among Hershey's competitors on September 4 or September 18. We hasten to add, however, that Hershey's abnormal return on July 25 is far larger than those of its competitors, and Hershey also experienced large, significant abnormal returns in the predicted directions on September 4 and September 18. Hence, we remain confident that most of the observed HSY abnormal return on July 25 is attributable to news of the sale.

To get a sense of how much of the HSY abnormal return on July 25 should be attributed to news of the sale, we estimated a market model in which we regressed the HSY return on the S\&P 500 return, as before, as well as the returns for CSG, TR, and CAG. This augmented estimation model therefore accounts for correlation among these firms. ${ }^{248}$ The HSY abnormal return for July 25, 2002 using this augmented estimation model is presented in Table 5.

\section{Table 5}

HSY Returns Controlling for Correlations with Competitors

\begin{tabular}{llcccc}
\hline \hline Date & Event & Actual & Expected & Abnormal & $\begin{array}{l}\text { Standardized } \\
\text { Abnormal }\end{array}$ \\
\hline $7 / 25 / 2002$ & $\begin{array}{l}\text { Sale } \\
\text { Announced }\end{array}$ & 0.253 & 0.026 & 0.226 & $20.545^{\star \star \star}$ \\
& & & & \\
\hline & $\begin{array}{l}\text { Note: }{ }^{* \star *} p<0.001 ;{ }^{* \star} p<0.01 ;{ }^{*} p<0.05 \\
\text { levels respectively). }\end{array}$
\end{tabular}

In Table 5 the standardized abnormal return for Hershey on July 25, 2002 is slightly smaller than in Table 3, but it is still quite large and highly statistically significant. ${ }^{249}$ Accordingly, we conclude that news of the sale was the primary explanation for the run up in HSY on July 25.

As in our analysis of HSY alone, another way to view the results is in a graphical depiction of cumulative abnormal returns. Figures $5 \mathrm{~b}$ and $5 \mathrm{c}$ plot the cumulative abnormal returns for HSY in comparison to its chocolate market competi-

248 We used the 100 trading days before the Hershey sale window for our estimation period, though as before the results are virtually unchanged if we use alternate estimation periods.

249 The results of the augmented model for the other key dates of interest are likewise consistent with those presented in Table 3. 
tors and its food manufacturing competitors respectively, each for the sale window plus 25 trading days before and after the window. ${ }^{250}$

Figure 5b:

Cumulative Abnormal Returns

Chocolate Competitors

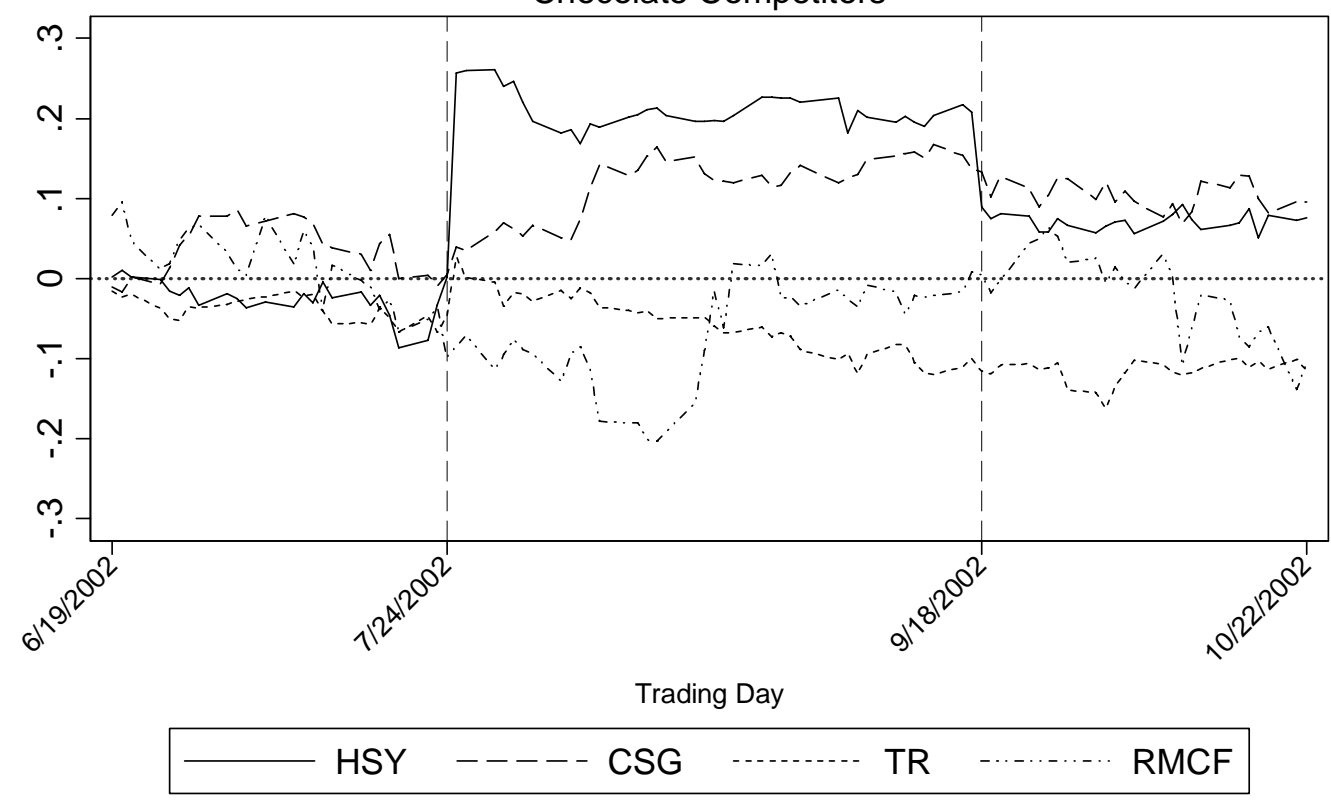

250 As in Figure 5a, see supra note _, in our expected returns regression for Figures $5 \mathrm{~b}$ and $5 \mathrm{c}$ we use as our estimation period the 100 trading days before the first trading day plotted. 
Figure 5c:

Cumulative Abnormal Returns

Food Competitors

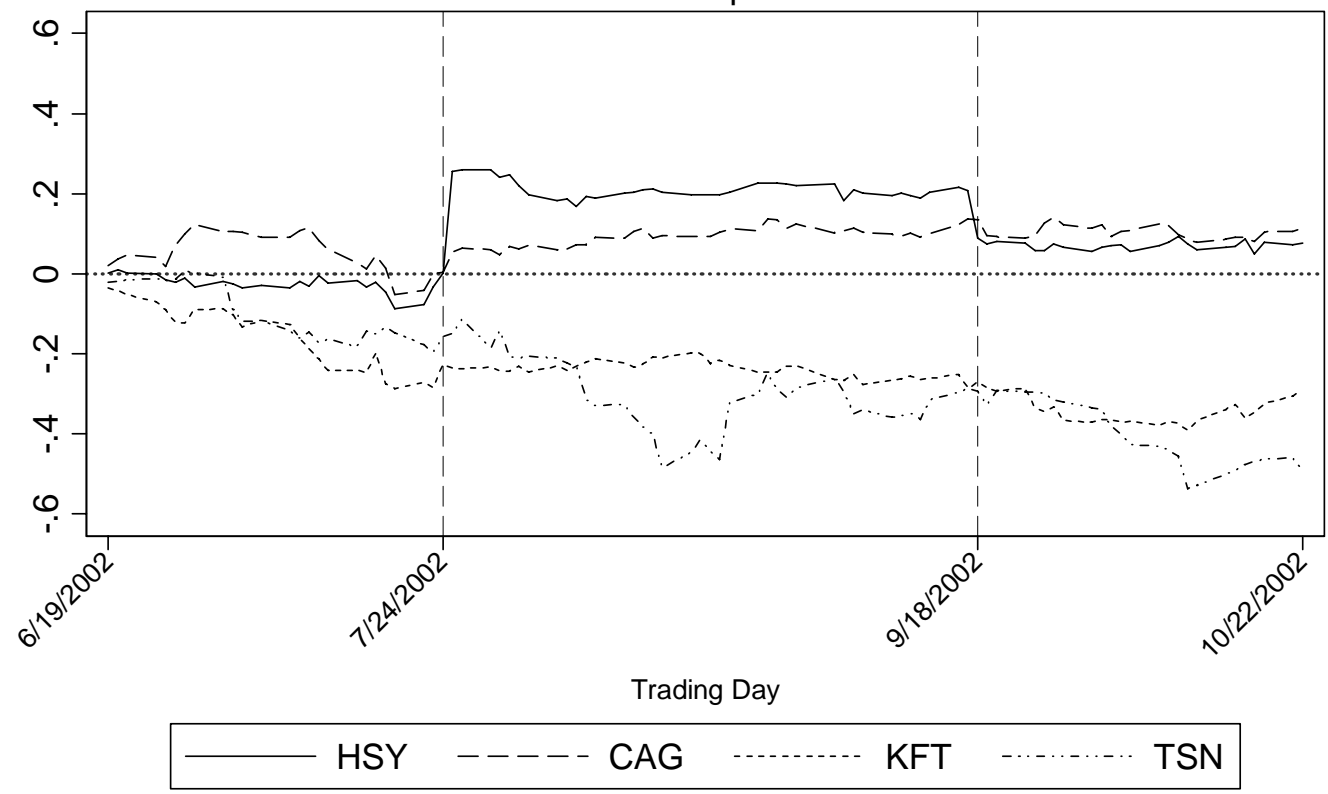

Figures 5b and 5c show that the pattern of HSY's cumulative abnormal returns bears little relation to that of most of its competitors. Although we do observe some comovement in the cumulative abnormal return of HSY with those of CSG, TR, and CAG at the beginning of the sale window, for CSG and TR this correlation does not continue through the rest of the window, and there is no appreciable comovement in the periods before or after the sale window. With respect to CAG, the relationship appears to persist even at the end of the sale window and beyond, though CAG's decline at the end of the sale window is not as pronounced as that observed for HSY. Moreover, HSY's cumulative abnormal return exceeds CAG's during the sale window but trails CAG's before and after the window. Accordingly, these graphs provide further evidence that HSY's abnormal returns during the sale window were driven by news related to the proposed sale, not generic chocolate or food market forces.

\section{The Problem of a Single-Firm Event Study}

Our study is limited by necessity to a single firm. Although one-firm event studies appear in the academic literature ${ }^{251}$ and are used routinely in securities liti-

251 See, e.g., Mark Weinstein, Don't Leave Home Without It: Limited Liability and American Express, _ J. Leg. Stud. _ (forthcoming 2008); Frederick Warren-Boulton \& Serdar Dalkir, Staples and Office Depot: An Event-Probability Case Study, 19 Rev. Ind. Org. 467 (2001); Stephen P. Baginski, Richard B. Corbett, \& William R. Ortega, Catastrophic Events and Retroactive Liability Insurance: The Case of the MGM Grand Fire, 58 J. Risk \& Ins. 247 (1991). 
gation, ${ }^{252}$ they nonetheless pose special problems owing to the greater volatility experienced by a portfolio of one than a portfolio of many securities. In Appendix Table B1, for example, we find that six of the 10 days prior to the sale announcement experienced a statistically significant abnormal return. Here the concern is that we might attribute statistical significance to an abnormal return that in fact reflects nothing more than random variation if the abnormal returns of the single firm are not well approximated by the normal distribution. In other words, our worry is that the normal critical values used to determine statistical significance (i.e., \pm 1.96 , \pm 2.575 , and \pm 3.277 for $.05, .01$, and .001 respectively) may not be appropriate given the weakened signal to noise ratio in a single-firm event study.

An initial answer to this concern is that the magnitude of the abnormal returns for July 25 (the sale announcement) and September 18 (the sale cancellation) are so large that as a mathematical matter they are statistically significant in all possible abnormal return distributions. This is an application of Chebyshev's inequality that we detail more formally in Appendix C.

However, reliance on Chebyshev's inequality assumes that we have correctly estimated the HSY abnormal returns. That assumption is problematic if the observed volatility of HSY in the 100 days prior to the event are not a reliable indicator of the volatility that HSY would have experienced during the event period but for the event. Here the limitation to a single firm is worrisome if the firm's volatility (that is, the variance in HSY's abnormal returns) could be changing over time. Accordingly, we must consider the possibility that the variance we estimated in the pre-sale period was coincidentally low relative to other periods.

As initial check against this worry, as detailed above we also computed HSY's abnormal returns with reference to the observed volatility of HSY in a variety of alternative estimation windows. Some of those alternatives used only days after the sale window. Others were pooled models in which we used days before and after the sale window.

As a further cautionary measure, we undertook a randomization inference robustness check by performing event studies on HSY's returns for 600 days randomly chosen during the three years before and after the sale window. ${ }^{253}$ We then calculated the standardized abnormal returns for each of those dates to determine how frequently various standardized abnormal return levels occurred in the random sample. Next, we used these values to generate a probability density function. This

252 See, e.g., In Re Xcelera.com Securities Litigation, 430 F.3d 503, 512-14 (1st Cir. 2005); U.S. v. Grabske, 260 F.Supp.2d 866, 867-69 (N.D. Cal. 2002). See also In re Imperial Credit Industries, Inc. Securities Litigation, 252 F.Supp.2d 1005, 1014 (C.D. Cal. 2003) (stating that the plaintiffs' expert's report was "deficient for failure to provide an 'event study' or similar analysis").

253 We used the Eventus software available through Wharton Data Services and the CRSP value weighted index as our market portfolio. The output from this analysis is available at http://mailer.fsu.edu/ jklick/research.html. 
randomization inference approach has been used in other applications, ${ }^{254}$ but we believe that we are the first to use it in an event study in the law and economics literature.

The estimated probability distribution, superimposed over a standard normal distribution, is presented in Figure 6a.

Figure 6a:

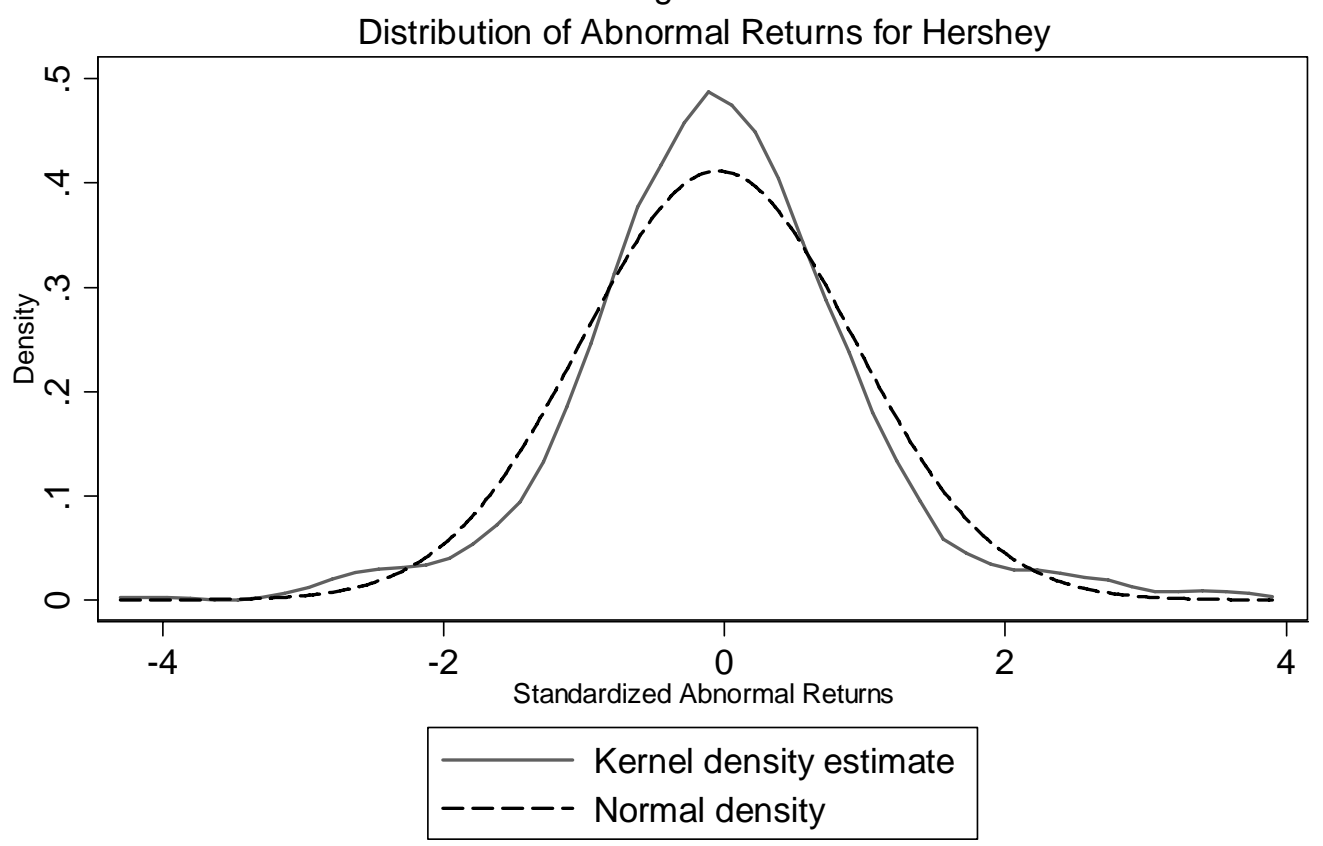

600 Days Randomly Selected from Period July 1999 to July 2005 (excluding sale window)

Although the HSY-specific probability distribution appears roughly to approximate the normal distribution, the two are not perfectly congruent. Using the estimated probability distribution, we computed a set of HSY-specific critical values or significance thresholds. These HSY-specific critical values are not perfect, of course, because some of the 600 randomly chosen days might in fact have experienced an abnormal return owing to unanticipated events on those days. Nonetheless, these HSY-specific critical values provide a useful check on whether our findings are artifacts of normal volatility rather than news of the sale.

Using our Figure 6a HSY-specific critical values, the observed HSY abnormal return on July 25 , the date the sale plan was made public, was still highly statistically significant (less than the 0.1 percent level). The observed HSY abnormal return on September 18, the first trading day after the sale was abandoned, also remained strongly significant, though somewhat less so than we determined using the critical values from the normal distribution (0.2 percent level, still highly signifi-

254 See, e.g., Daniel Ho \& Kosuke Imai, Randomization Inference with Natural Experiments: An Analysis of Ballot Effects in the 2003 California Recall Election, 101 J. Amer. Stat. Assoc. 888 (2006); John Donohue \& Daniel Ho, The Impact of Damage Caps on Malpractice Claims: Randomization Inference with Difference-in-Differences, 4 J. Emp. Leg. Stud. 69 (2007). 
cant). By contrast, the significance level of the observed HSY abnormal return on September 4 (the date of the injunction) fell to the 9 percent level. Accordingly, assessing statistical significance in relation to our estimated HSY-specific probability function largely confirms our earlier results using the normal distribution. Although the September 4 date fell below the conventional threshold of 5 percent for statistical significance, the results for the date the sale was announced and the date the sale was abandoned remained strongly significant.

We performed a similar analysis using the abnormal returns from event studies on 100 randomly chosen days for each of Hershey's six competitors identified above during the three years before and after the sale window. ${ }^{255}$ The results of this analysis provide us with another benchmark against which to compare HSY's abnormal returns. For example, perhaps during this general time period abnormal returns for companies in this general industry are not well approximated by the normal distribution because of industry-wide increased volatility or structural changes in the market. While the distribution in Figure 6a addresses this worry, a second comparison is useful to put our major results into additional context. Figure $6 \mathrm{~b}$ presents the estimated probability distribution from our examination of Hershey's competitors superimposed over a standard normal distribution.

\footnotetext{
255 As before, we used the Eventus software and the CRSP value weighted index as our market portfolio. The output from this analysis is available at http://mailer.fsu.edu/ jklick/research.html. Note that this analysis does not actually include 600 data points as would be expected with 6 firms and 100 randomly chosen days. During a few of the randomly chosen days early in the sample, RMCF and KFT were not traded on the NYSE, leaving us with 556 observations on which we could base this analysis. RMCF was newly listed during our sample period and KFT was private during the early part of our period. While it would have been possible to restrict date selection to only those days during which all firms traded, doing so has the potential to introduce a bias into our analysis, so we opted to allow for the selection of days where some of the firms were not trading.
} 
Figure 6b:

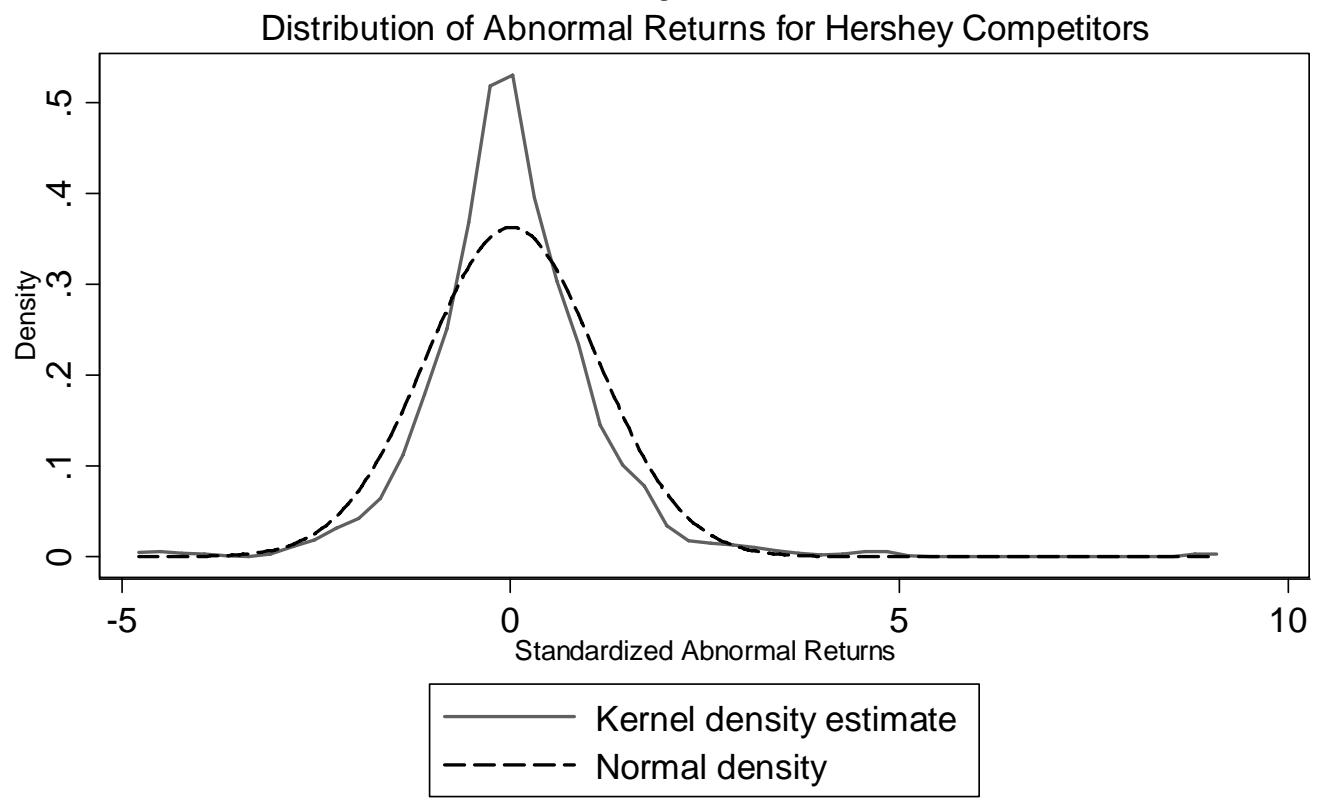

100 Days Randomly Selected from Period July 1999 to July 2005 (excluding sale window) Firms Included: CSG; TR; RMCF; CAG; KFT; TSN

Using the critical values from the distribution depicted in Figure $6 \mathrm{~b}$, the statistical significance of the abnormal returns presented in Table 3 associated with news of the trustees' plan to sell and the abandonment of the sale are literally off the chart. No competitor in the sample had a standardized abnormal return greater than 8.9, but HSY's standardized abnormal returns on July 25 and September 18 (the sale announcement and termination dates) were 21.25 and 9.83 respectively. Further, the statistical significance of the abnormal return on the day of the injunction goes from 9 percent in the prior analysis (using the distribution of Figure 6a) to 1.3 percent using the distribution of Figure $6 \mathrm{~b}$. Hence, under this approach, we find no reason to suspect that HSY's abnormal returns on the days of interest were the result of mere random variation. ${ }^{256}$

\section{Summary of Empirical Findings}

The evidence is strongly consistent with our hypothesis of agency costs in charitable trust governance. The evidence is also strongly consistent with the widely-held belief that supervision of charitable trusts by state attorneys general is deficient. Indeed, in this case the attorney general's intervention was counterproductive, both reducing aggregate social welfare and imposing unnecessary agency costs on the Trust. Finally, the evidence indicates that the capital markets rated the

256 Our approach of benchmarking abnormal returns to a distribution generated from HSY during periods outside the sale window and to a distribution generated from HSY's competitors bears some similarity to the bootstrapping methods introduced in John D. Lyon, Brad M. Barber, \& Chih-Ling Tsai, Improved Methods for Tests of Long-Run Abnormal Stock Returns, 54 J. Fin. 165 (1999). We thank Dan Rubinfeld and Max Schanzenbach for stimulating our thinking on alternative benchmarks and bootstrapping. 
threat of a takeover as superior to the Trust's controlling position for minimizing agency costs in the Hershey Company. We summarize the evidence and our specific findings here.

Graphical examination of Hershey's stock price, both by itself and in comparison to that of its main NYSE-traded competitors, strongly suggests that news of the trustees' plan to sell the Trust's controlling interest in the Company led to an increase in the Company's stock price. Graphical analysis likewise strongly implies that abandonment of the sale led to a decrease. However, comparison of Hershey's stock price dynamics with those of broad market indexes reveals some comovement of Hershey's stock with the market as a whole, leading us to apply more rigorous methodology to isolate the effects of the proposed sale independent of other effects.

Using a standard event study econometric analysis that isolates stock price movement attributable to sale-related news from general market trends, we find that Hershey's stock experienced a large and statistically significant positive abnormal return on news of the sale and a large and statistically significant negative abnormal return on the trustees' abandonment of the sale. These findings endure across a variety of specifications and numerous robustness checks. ${ }^{257}$ In most specifications we also find that the trial court's issuance of an injunction against the sale led to a statistically significant negative abnormal return.

Put into numerical terms, we find that news of the trustees' plan to sell the Trust's controlling interest in the Company was associated with a statistically significant positive abnormal return of 25.5 percent. This finding implies that the Hershey Company was worth $\$ 2.7$ billion more on the open market than when under the control of the trustees. ${ }^{258}$ Accordingly, in this case the existence of a controlling shareholder was manifestly inferior to the market for corporate control as an alternative mechanism for minimizing corporate agency costs.

257 Indeed, our findings regarding the effect of the sale announcement and sale abandonment were significant in all specifications at better than the 99.8 percent level and in all but one at the 99.9 percent level.

258 The $\$ 2.7$ billion figure is the product of a back-of-the-envelope calculation that reflects 25.5 percent (our point estimate of Hershey's abnormal return) of Hershey's market capitalization of $\$ 10.7$ billion on July 25, 2002. The 95 percent confidence interval implies that the loss lies within the range of $\$ 2.4$ billion and $\$ 3$ billion. We computed Hershey's market capitalization by multiplying the number of outstanding shares by Hershey's July 25, 2002 closing price of $\$ 78.30$. Our share volume data, which reflects the number of shares outstanding on July 26, 2002, comes from The Hershey Company, Form 10-Q, Quarterly Report for the Quarter ended June 30, 2002, at 1 (filed Aug. 7, 2002).

An alternate measure of the social cost might be possible using the negative abnormal return that occurred when the sale was abandoned. We hesitate to use this measure, however, because at various dates in the sale window the abandonment of the sale was probabilistically capitalized into the HSY price. This can be seen most clearly on the day the court issued a preliminary injunction against the sale. Thus, using this alternate measure requires subjective judgments about what total abnormal return we can attribute to expectations that the sale would be abandoned. The first public disclosure of the proposed sale is a cleaner and better identified shock to Hershey's exposure to the market for corporate control. 
Regarding trust law, our findings imply agency costs arising from the Hershey Trust's charitable trust form on the order of $\$ 850$ million, ${ }^{259}$ about 15 percent of the 2002 value of the Trust. 260 Although the trustees controlled more than threequarters of the votes in the Hershey Company, they failed to impose a valuemaximizing strategy on the Company's managers. As we have seen, the market judged the Company as being $\$ 2.7$ billion (or 25.5 percent) more valuable when the Company's managers were expected to be subject to the market for corporate control instead of supervision by the trustees.

Moreover, instead of reducing the agency costs associated with the Trust's charitable trust form, the attorney general's intervention made those agency costs permanent. Without any offsetting financial benefit for the Trust, the attorney general forced the Trust to retain an asset that was worth $\$ 850$ million more on the open market than in the hands of the trustees. While the sale detractors argued that the sale would hurt other stakeholders such as the residents of Hershey and the Hershey workers, one wonders whether their gain offsets the preservation of rampant agency costs. The $\$ 850$ million in Trust assets destroyed translates roughly to a $\$ 67,000$ transfer from the Trust to each resident of Hershey, or a $\$ 62,000$ transfer to each worker at the Hershey Company, plus continued exposure to uncompensated risk. $^{261}$

Given our results in Appendix Table B1 regarding potential leakage, the foregoing estimates may well understate the true measure of agency costs and hence the social welfare loss. If we included the abnormal returns for the three days before the announcement, our estimates would be roughly 8 percent higher. ${ }^{262}$

259 As with our $\$ 2.7$ billion figure, this $\$ 850$ million figure reflects a back-of-the-envelope calculation that extrapolates from our point estimates. Specifically, $\$ 850$ million is the rounded-down product of multiplying the percent of outstanding HSY stock held by the Trust by the $\$ 2.7$ billion figure computed in supra note _. Our 2002 share volume data reported in supra Table 1 comes from The Hershey Company, SEC Form 10-K, Annual Report for the fiscal year ended December 31, 2002, at 66-68 (filed Feb. 28, 2006). The 95 percent confidence interval implies that the loss lies within the range of $\$ 760$ million and $\$ 940$ million.

260 See supra Table 1.

261 The population and employment figures used in this computation come from the 2000 Census and filings by the Hershey Company with the SEC. See http://www.census.gov; The Hershey Company, Form 10-K, Annual Report for the Fiscal Year ended December 31, 2002, at 4 (filed Mar. 26, 2003).

262 Still another alternate measure of the loss to shareholders (including the Trust) from abandoning the sale might be derived from Wrigley's $\$ 12.5$ billion bid. That bid translates to $\$ 89$ per share, which is $\$ 26.50$ or 42.4 percent more than HSY's closing price of $\$ 62.50$ on July 24,2002 , the day before news of the sale broke. Using these figures (see supra notes 258-259 for discussion of methodology), the total loss to shareholders amounts to roughly $\$ 5.1$ billion, of which the Trust's share is $\$ 1.6$ billion. However, we are skeptical of using the Wrigley bid for this purpose. While Wrigley's $\$ 12.5$ billion bid might represent the value of the Hershey Company's assets under the control of Wrigley's management, a portion of that sum might also reflect agency costs in the Wrigley corporate structure. For example, the bid might include a control premium that Wrigley's management was willing to pay for the purposes of empire building or takeover protection. See II.B(1)(b). As such, the Wrigley bid is a less reliable benchmark for assessing the welfare effects of terminating the sale than our estimate of the Hershey Company's abnormal return on July 25. The same analysis applies to the use of other bids. 


\section{IMPlications For Policy ANALYSIS}

\section{A. Charitable Trusts}

We have shown that the Hershey Trust's principal asset, its stock in the Hershey Company, was worth $\$ 850$ million more (about 15 percent of the Trust's 2002 value) on the open market than when in the hands of the trustees-a damning indictment of the trustees' inability to use their voting control of the Hershey Company to maximize value. We have also shown that the attorney general's intervention to block the sale of the Hershey Company forced the Trust to maintain an undiversified and smaller portfolio. Our analysis therefore provides the first quantitative empirical evidence of agency costs in the charitable trust form and the inadequacy of supervision of charitable trusts by the state attorneys general. As such, our findings provide an empirical grounding for at least three policy debates in the law of trusts: (1) the utility of alternative modes of charitable trust supervision; (2) the authorization of cy pres of charitable trusts on the ground of "wastefulness"; and (3) the propriety of social investing by trustees and other fiduciaries.

(1) Alternative modes of supervision. Although it is widely believed that the supervision of charitable trusts by the state attorneys general is inadequate, there is disagreement over the reasons and best remedy for that inadequacy. On one view, supervision is inadequate because of insufficient resources. ${ }^{263}$ Proponents of this view contend that increasing the budget for charitable supervision and perhaps also increasing the mandatory disclosure obligations of charitable organizations will improve oversight. ${ }^{264}$ Another view holds that the state attorneys general are lackadaisical monitors of charities because active supervision has little political payoff. ${ }^{265}$ On this view increased funding and disclosure will have minimal effect because the problem is structural. Instead, alternative modes of supervision by people or entities with better incentives are required.

Our findings tend to support the latter view. As we have seen, even if the attorney general does intervene, the attorney general's narrow political interests might not be congruent with the best interests of the Trust or social welfare-here to the tune of $\$ 850$ million and $\$ 2.7$ billion respectively. The broader point is that no amount of additional funding or increased disclosure will ameliorate the underlying structural problem that the attorney general is typically a political officer whose ambition toward higher office provides little incentive to supervise charitable trusts

263 See, e.g., Johnson, supra note _ , at 389 ("I attribute the failure of the attorneys general not to lack of interest or improper motive, but to the lack of funds devoted specifically to this purpose."). See also Brody, Parochialism, supra note _, at $951 \&$ n.50 (collecting studies on the few resources allocated to charity enforcement).

264 See Johnson, supra note _, at 390 (proposing that charitable trusts pay a fee that would fund the attorney general's supervision); Gary, supra note _, at 639-41 (urging increased disclosure), 646 (proposing increased funding). See also Chester, supra note _ (discussing increased disclosure and charitable enforcement); Reiser, Disclosure, supra note _ (same); Fishman, supra note _ , at 270-72 (same).

265 See, e.g., Brody, Parochialism, supra note__, at 947-49. 
or perverse incentives to impose local political preferences. ${ }^{266}$ In either scenario, resources held by tax-exempt and so publicly-subsidized charitable trusts are not deployed in efficient pursuit of a bona fide charitable purpose for the public good.

To be sure, we do not claim that all charitable trusts host the same magnitude of agency costs as the Hershey Trust. Nor do we claim that all interventions by state attorneys general are as maladroit as the intervention here. Instead our claim is that our results tend to validate the assumption in the theoretical literature, heretofore based chiefly on qualitative anecdotal evidence, of the prevalence of agency costs in charitable trusts and the failure by the state attorneys general adequately to superintend such trusts. Further, by showing that the attorney general's intervention here reduced the value of the Trust and continued its exposure to uncompensated risk, our findings tend to support the view that the incentives of the attorney general may well be misaligned with the best interests of the Trust. Our findings offer tentative support for alternative modes of supervision by agents with better incentives.

For example, some have argued that, because the IRS is less vulnerable to local political capture, its role in supervising the operation of charitable entities should be expanded, ${ }^{267}$ and indeed the IRS has become more aggressive in policing charitable entities. ${ }^{268}$ Others have argued for an independent federal agency, perhaps on the model of the Securities and Exchange Commission. ${ }^{269}$ Almost half the states have given donors standing concurrent with the attorney general to enforce a charitable trust. ${ }^{270}$ And a handful of states allow relator standing to enforce charitable trusts - that is, standing for individuals in cases where the attorney general

266 See Brody, Parochialism, supra note _. See also Mark Sidel, The Nonprofit Sector and the New State Activism, 100 Mich. L. Rev. 1312 (2002) (discussing “activist state authorities”).

${ }^{267}$ See, e.g., Gary, supra note _, at 644-45; Evelyn Brody, A Taxing Time for Bishop Estate: What is the I.R.S. Role in Charity Governance?, 21 U. Haw. L. Rev. 537 (1999).

268 See, e.g., Gary, supra note _, at 629-34; IR-2004-106 (Aug. 10, 2004) (announcing "a new enforcement effort to identify and halt abuses by tax-exempt organizations that pay excessive compensation and benefits to their officers and other insiders"). If the Hershey Trust were a foundation rather than a Trust, its concentration in the Hershey Company would offend I.R.C. 4943. See supra note 75.

269 See, e.g., Fleishman, supra note _, at 188-91; Fleishman, supra note _, at 256-59; Karst, supra note _, at 83. However, such an agency might be vulnerable to capture by charitable managers. See Jonathan R. Macey, Administrative Agency Obsolescence and Interest Group Formation: A Case Study of the SEC at Sixty, 15 Cardozo L. Rev. 909, 913-15 (1994). Further, the English experience with a charities regulatory agency, the English Charity Commission, has not been entirely happy. See, e.g., Debra Morris, New Charity Regulation Proposals for England and Wales: overdue or Overdone?, 80 Chi.-Kent L. Rev. 779 (2005); James J. Fishman, Charitable Accountability and Reform in Nineteenth Century England: The Case of the Charity Commission, 80 Chi.-Kent L. Rev. 723 (2005).

270 See supra note 29. See also Restatement (Third) of Trusts $\$ 94$ cmt. g (P.D. No. 8, 2007). Hansmann urged this reform over 25 years ago. See Henry B. Hansmann, Reforming Nonprofit Corporation Law, 129 U. Pa. L. Rev. 497, 609 (1981). For more recent analysis, see Iris J. Goodwin, Donor Standing to Enforce Charitable Gifts: Civil Society vs. Donor Empowerment, 58 Vand. L. Rev. 1093 (2005); Ronald Chester, Grantor Standing to Enforce Charitable Transfers Under Section 405(C) of the Uniform Trust Code and Related Law: How Important Is It and How Extensive Should It Be?, 37 Real Prop. Prob. \& Tr. J. 611 (2003). For a contrary analysis, see Rob Atkinson, Unsettled Standing: Who (Else) Should Enforce the Duties of Charitable Fiduciaries?, 23 J. Corp. L. 655 (1998). 
elects not to pursue the matter. ${ }^{271}$ Perhaps most intriguing (albeit still theoretical), Geoffrey Manne has urged "the creation of private, for-profit monitoring companies" that would contract with charitable organizations "to monitor both the financial and charitable aspects of the nonprofit's operation." 272

Each of these proposals, of course, presents pros and cons in the particulars that we pass over here. Weighing those pros and cons is beyond the scope of this paper, hence the qualifier that our findings offer "tentative" support. For present purposes, it suffices to note that the theme that ties each of these reforms togetherand what makes each potentially attractive in view of our findings-is that they are more sensitive to the private incentives of the agents charged with supervision. Indeed, several are designed to harness those incentives, particularly donor standing.

(2) Cy Pres for Wastefulness. Under the traditional understanding of the cy pres doctrine, a court may direct the trustees of a charitable trust to apply the trust property to another charitable purpose that approximates the donor's original purpose if the original purpose becomes impossible, impracticable, or illegal. ${ }^{273}$ The principal justification for the doctrine is the risk that, because a charitable trust may have a perpetual existence, there is a good possibility that changed circumstances will render the trust's original purpose obsolete. ${ }^{274}$ As Bruce Mann has explained, "the law of charitable trusts has never regarded a donor's wishes as inviolate, regardless of what anyone, donors included, might think or want. All the law promises is that it will do its best to honor those wishes-literally if possible, by approximation if not." 275 Thus the leading casebook offers the example of a "nineteenth-century trust to care for old horses retired from pulling fire wagons and streetcars" as a good candidate for cy pres. ${ }^{276}$

Recently, however, there has been a movement to broaden the grounds for cy pres to include "wasteful." The idea is to account for "the increasingly frequent problem of trust funds that have become excessive for their stated charitable purpose."277 Under this reformed conception of cy pres, if the trust property so "exceeds what is needed for the particular charitable purpose ... that the continued expenditure of all the funds for that purpose ... would be wasteful," then a court "might broaden the purposes of the trust," for example by "direct application of the surplus funds to

\footnotetext{
271 See Gary, supra note _, at 626-27. See also Restatement (Third) of Trusts $\$ 94$ cmt. e (P.D. No. 8,2007 ) (discussing relator standing). A related idea is the appointment of a trustee ad litem. See Kaufman, supra note _, at 736-37.

272 Manne, supra note _, at 229. A public variant is Fishman's proposal for local charity commissions with members appointed by the governor and attorney general. See Fischman, supra note _, at 272-75.

273 See Restatement (Second) of Trusts §399 (1959).

274 See, e.g., Restatement (Third) of Trusts $§ 67 \mathrm{cmt}$. a (2003); Posner, supra note _, at 546.

275 See Bruce H. Mann, In the End, a Move Was Only Way Out, Phila. Inq., Dec. 15, 2004.

276 Dukeminier et al., supra note _, at 738.

277 Edward C. Halbach, Jr., Uniform Acts, Restatements, and Trends in American Trust Law at Century's End, 88 Cal. L. Rev. 1877, 1902 (2000).
} 
a like purpose in a different community."278 The 2000 Uniform Trust Code, now adopted in 19 states, the 2003 Restatement (Third) of Trusts, and the most recent preliminary draft of the Principles of Nonprofit Organizations all adopt "wasteful" as a basis for cy pres. ${ }^{279}$

Whatever the other merits of broadening the grounds for cy pres, our findings suggest that cy pres in the case of an excess endowment may have the salutary effect of minimizing agency costs. Given the Hershey Trust's excess endowment, another $\$ 850$ million would have had little effect on the Trust's ability to fund the dayto-day operation of the School. As a result, there was little pressure on the trustees to maximize value, and little risk for the attorney general that blocking the sale would immediately imperil the School. Indeed, opponents of the trustees' diversification plan argued that the Trust had more money than it needed for its specific purpose and hence the Trust should not be allowed to diversify.

By contrast, if the trustees were under pressure to use the Trust's excess endowment to fund similar schools in other communities (recall that the trust instrument gives preference to local orphans but allows for admission of orphans from across the country ${ }^{280}$ ), the social welfare loss from failing to maximize the value of the Trust would have been more apparent. Recall that although the Trust's corpus has grown dramatically, the School "served no more children at the start of 2005 than it did in 1963." 281

Put more broadly, our findings tend to confirm the theoretical intuitions that an excess endowment provides a cushion for managerial laxity ${ }^{282}$ and invites imposition of local political preferences by state officials. ${ }^{283}$ Recall that upon amending the state's prudent investor law to make it difficult for the trustees in the future to jus-

278 Restatement (Third) of Trusts $\$ 67$ cmt. c(1) (2003).

279 See Uniform Trust Code $§ 413(\mathrm{a})$; Restatement (Third) of Trusts $§ 67$ (2003); Principles of the Law of Nonprofit Organizations $\S \S 240,440$ (P.D. No. 4, 2007). All but 3 of the 19 UTC states have enacted UTC $§ 413(\mathrm{a})$. See http://www.utcproject.org/utc/DesktopDefault.aspx?tabindex=0\&tabid=1 (providing UTC enactment charts). See also David M. English, The Uniform Trust Code (2000): Significant Provisions and Policy Issues, 67 Mo. L. Rev. 144, 179 \& n.164 (2002) (explaining that, under the UTC, cases of waste would "normally involve situations where the funds allocated to the particular charitable scheme far exceed what is needed").

280 See text accompanying supra note 53.

281 D'Antonio, supra note _, at 266.

282 See Henry Hansmann, Why Do Universities Have Endowments?, 19 J. Leg. Stud. 3, 29 (1990). Our agency costs justification of permitting cy pres on the ground of "wasteful" shares an analytical overlap with the proposal by Richard Posner and others that charitable foundations be required to spend down all property received within a limited timeframe. Posner, supra note _, at 547; Joel L. Fleishman, The Foundation: A Great American Secret 235-48 (2007). Perhaps the most prominent example is the Gates Foundation's decision to terminate 50 years after the death of the survivor of Bill Gates, Melinda Gates, and Warren Buffett. See Sally Beatty, Gates Sets Time Frame To Spend Assets, Wall St. J. A10 (Dec. 1, 2006). Our analysis also fits neatly with the literature on agency problems associated with excess endowments in operating nonprofit firms. See Core et al., supra note _ ; Raymond Fisman \& R. Glenn Hubbard, The Role of Nonprofit Endowments, in Glaeser, supra note _, at 217-33. 283 See Brody, Parochialism, supra note _. See also text accompanying note 161. 
tify selling the Trust's interest in the Company, the state Senate majority leader explained that "[w]e have to be active and protect our economic assets." 284

(3) Propriety of Social Investing by Trustees and Other Fiduciaries. There is ongoing debate about whether trustees and other fiduciaries may properly engage in social investing, that is, "investing in pursuit of an investment strategy that tempers the conventional objective of maximizing the investor's financial interests by seeking to promote nonfinancial social goals as well." ${ }^{285}$ As we have seen, the $\$ 850$ million in assets not realized by the Trust is roughly equivalent to a $\$ 67,000$ transfer from the Trust to each resident of Hershey, or a $\$ 62,000$ transfer to each worker at the Hershey Company. ${ }^{286}$ By quantifying the loss to the Trust and the gain to these other constituencies, our findings bring into sharp relief the important policy questions of (a) whether the gain to these other constituencies offsets the wealth destruction experienced by the Trust, the Trust's continuing exposure to uncompensated risk, and the wealth destruction experienced by the Company's other shareholders, and (b) whether that question is even relevant as a matter of law or policy. ${ }^{287}$

Under orthodox trust fiduciary law, "[n]o form of so-called 'social investing' is consistent with the duty of loyalty if the investment entails sacrificing the interests of trust beneficiaries ... in favor of the interests of the persons supposedly benefited by pursuing the particular social cause." 288 Because the Hershey Trust's charitable purpose is to board and educate needy children from across the country, not to subsidize life in Hershey, Pennsylvania, the Trustees could not permissibly maintain the Trust's controlling interest in the Company for the purpose of promoting the interests of the town and the Company's workers.

284 See supra notes 157-161 and text accompanying.

285 Langbein \& Posner, supra note _, at 73. See, e.g.,Michael S. Knoll, Ethical Screening in Modern Financial Markets: The Conflicting Claims Underlying Socially Responsible Investment, 57 Bus. Law. 681 (2002); Lewis D. Solomon \& Karen C. Coe, Social Investments by Nonprofit Corporations and Charitable Trusts: A Legal and Business Primer for Foundation Managers and Other Nonprofit Fiduciaries, 66 UMKC L. Rev. 213 (1997); Joel C. Dobris, Arguments in Favor of Fiduciary Divestment of "South African" Securities, 65 Neb. L. Rev. 209 (1986).

286 See supra note _ and text accompanying.

287 Our analysis has an analogy in the question of whether corporate managers should consider the welfare of constituencies other than shareholders. See, e.g., Einer Elhauge, Sacrificing Corporate Profits in the Public Interest, 80 N.Y.U. L. Rev. 733 (2005); Jonathan R. Macey, An Economic Analysis of the Various Rationales for Making Shareholder the Exclusive Beneficiaries of Corporate Fiduciary Duties, 21 Stetson L. Rev. 23 (1991).

288 Uniform Prudent Investor Act $\$ 5 \mathrm{cmt}$ (1994). For a more general treatment, see Langbein \& Posner, supra note _. Federal pension law follows the orthodox view. See Interpretive Bulletin IB 941, codified at 29 C.F.R. §2509.94-1; Ian D. Lanoff, The Social Investment of Private Pension Plan Assets: May It Be Done Lawfully Under ERISA?, 31 Labor L.J. 387 (1980). In 2002, however, Pennsylvania modified its prudent investor rule to require the trustee of a charitable trust to consider "the special relationship of [a trust asset] and its economic impact as a principal business enterprise on the community.” See supra notes _ and text accompanying. 
But suppose the Trustees could permissibly take into account the interests of these other constituencies. ${ }^{289}$ Even if the Trust's purpose were to subsidize life in Hershey, it is hardly obvious that maintaining control of the Hershey Company would be an efficient way to do so. For example, the Trust could have sold its interest in the Hershey Company, thereby realizing the $\$ 850$ million gain and diversifying its portfolio, and then it could have paid out every dollar of that $\$ 850$ million gain to the local community. In this scenario, the community would have received an $\$ 850$ million transfer from the Trust, the Company would thereafter be subject to the pressures of the takeover market, and the Trust would have at least achieved salutary portfolio diversification. Instead, the Trust was forced to maintain its interest in the Company (and so an undiversified portfolio), the community did not receive a cash transfer, and the Company remained subject to the less efficient monitoring of the trustees. The bill for this inefficiency ultimately came due in early 2007 when, after further erosion of the Company's market share, the Company announced that it would close one-third of its assembly lines, layoff 1,500 workers (12 percent of its workforce), and open a new factory in Mexico. ${ }^{290}$

A similar analysis pertains to shareholder welfare. To make the abandonment of the sale welfare neutral (i.e., Kaldor-Hicks efficient) with respect to shareholders, each of Hershey's 13,700 workers on average would have to value blocking the sale at more than $\$ 199,000$, or, alternately, each of Hershey's 12,771 residents on average would have to value blocking the sale at $\$ 214,000 .{ }^{291}$ To be sure, the public shareholders knew or should have known that the Trust had voting control over the Company, and hence those shareholders bought their shares at a discount reflecting the Trust's continuing control. Nonetheless, from an aggregate social welfare perspective, canceling the sale preserved a suboptimal capital structure on the order of $\$ 2.7$ billion.

289 Indeed, as amended in 2002 in the wake of the aborted sale, see supra notes 157-161 and text accompanying, the Pennsylvania prudent investor law now deviates from the norm by expressly allowing the trustee of a charitable trust to consider "the special relationship of the asset and its economic impact as a principal business enterprise on the community in which the beneficiary of the trust is located and the special value of the integration of the beneficiary's activities with the community where that asset is located" when making investment decisions. Pa. Con. Stat., tit. 20, §7203(c)(6).

290 See Food Brief-Hershey CO.: Work Force Will Be Cut 12\% In Three-Year Restructuring, Wall St. J. B5 (Feb. 17, 2007); Hershey Cutting Work Force 12\%, N.Y. Times C2 (Feb. 16, 2007). Local media coverage suggested that that 3,000 local jobs would be lost, replaced by 1,500 jobs in Mexico. See Barbara Miller \& Monica Von Dobeneck, Patriot News A1 (Feb. 17, 2007).

291 These figures were computed using the same employment and population figures as before, see supra note _, but substituting $\$ 2.7$ billion for $\$ 850$ million. The Kaldor-Hicks efficiency criterion holds that an action is efficient if those who gain from the action benefit, in the aggregate, more than those who lose from the action, in the aggregate, such that it would be possible for the winners to compensate the losers, leaving everyone better off after the action is taken. In this case, if the workers (or residents) valued blocking the sale, on average, at an amount less than those provided above, it would not be possible for them to compensate shareholders for the wealth loss from blocking the sale. For a useful introductory discussion of efficiency measures, see William T. Allen, Reinier Kraakman, \& Guhan Subramanian, Commentaries and Cases on the Law of Business Organization 3-5 (2d ed. 2007); Francesco Parisi \& Jonathan Klick, Functional Law and Economics: The Search for Value-Neutral Principles of Lawmaking, 79 Chi.-Kent L. Rev. 431, 438 (2004). 


\section{B. Corporate Governance}

Our analysis bears on two policy debates in corporate governance: (1) the role of controlling shareholders or large blockholders in minimizing corporate agency costs, and (2) the role of the market for corporate control (i.e., the takeover market) in minimizing corporate agency costs.

(1) Controlling Shareholders in Corporate Governance. The incidence of controlling shareholders and minority blockholders is increasing among public U.S. firms and is even more common among public companies in Europe. ${ }^{292}$ We have shown, however, that the markets valued the Hershey Company as being $\$ 2.7$ billion more valuable (an increase of more than 25 percent) when its managers were subject to market discipline instead of supervision by the trustees as agents for the Trust. This finding suggests that a controlling shareholder, at least one whose agents are poorly motivated, provides less discipline against corporate agency costs than the takeover market. Indeed, the existence of a listless controlling shareholder or minority blockholder might have perverse governance consequences if it insulates the managers by foreclosing the possibility of a takeover.

To be sure, our results do not imply that a controlling shareholder can never effectively monitor agency costs within the firm. We cannot disentangle the role of the agency costs owing to the Hershey Trust's weak governance structure from the role of switching from a controlling shareholder to the market for corporate control as alternative explanations for our findings. But our findings do suggest that corporate agency costs will not be controlled if the individuals who make decisions for the controlling shareholder have little to gain from better performance. Although this point has been made in general terms before ${ }^{293}$ our empirical analysis puts the problem into sharp relief, suggesting a pair of related implications, one concerning the future empirical research agenda and the other concerning policy.

First, our analysis suggests that a blockholder's organizational form should be included as a variable in future empirical work on whether the existence of the blockholder has a positive effect on firm value. Indeed, the failure to control systematically for agency problems within the blockholder's form may explain why existing studies generally do not arrive at robust conclusions. ${ }^{294}$ By contrast, because our study is by necessity limited to a single blockholder whose governance structure is evident, we can speculate that it was the agency costs inherent to the Hershey Trust's charitable trust form that caused it to be a deficient monitor. With only one firm, however, we are not able to identify this incentive effect separately from Hershey's other idiosyncracies. Accordingly, our hypothesis regarding the importance of the blockholder's organizational form calls out to be tested in future studies.

292 See supra note _ and text accompanying.

293 See, e.g., Coffee, supra note _, at 1326; Black, supra note _, at 873.

294 See Holderness, supra note _, at 60 ("I would summarize the current learning on blockholders and firm value as follows. First, it has not been definitely established whether the impact of blockholders on firm value is positive or negative. Second, there is little evidence that the impact of blockholders on firm value - whatever that impact may be - is pronounced.”). 
Second, our analysis tends to validate the existing, generalized concern about agency costs within a controlling shareholder's internal structure. As we have seen, the Hershey Trust was a poor monitor of the Hershey Company, but the fact of the Trust's deficient supervision does not negate the possibility of efficacious supervision by a blockholder that is not impaired by its own agency problems. Thus, perhaps hedge fund activism, as championed by Marcel Kahan and Edward Rock, ${ }^{295}$ will be more effective and occur more frequently ${ }^{296}$ than activism on the part of mutual funds and pension funds. ${ }^{297}$ Unlike mutual fund and pension fund managers, who receive management fees on the order of 0.5 to 3 percent, ${ }^{298}$ hedge fund managers receive performance rewards in the neighborhood of an additional 15 percent. ${ }^{299}$ Further, because hedge funds tend to have fewer investors, the investors themselves may have more of an incentive to monitor actively. ${ }^{300}$

(2) The Market for Corporate Control. Our results make a modest contribution to the empirical literature that investigates the takeover model. Consistent with previous studies of the effect of a takeover bid on share prices, ${ }^{301}$ our finding of a large, significant positive abnormal return on exposing the Hershey Company's managers to the market for corporate control suggests that the disciplining effect of the takeover threat improves shareholder value. Indeed, we improve on those studies in that we are better able to exclude the alternative hypotheses that the observed increase in the target's price reflects (a) new information provided by the fact of the

295 See, Kahan and Rock, supra note _.

296 Consistent with the notion that hedge fund managers will have an incentive to engage in activism, April Klein \& Emanuel Zur, Hedge Fund Activism, NYU Law and Economics Research Paper No 06-41 (2006), available at http://ssrn.com/abstract=913362, finds that, in a sample covering 2003-2005, hedge funds did engage in significant activism and were generally successful in their efforts (Table 5), but Klein and Zur did not find that hedge funds target underperforming firms (Table 3) and they found mixed evidence regarding whether the hedge fund activism improved target firm efficiency (Tables IV and VI). Alon Brav, Wei Jiang, Frank Partnoy, \& Randall S. Thomas, Hedge Fund Activism, Corporate Governance, and Firm Performance, ECGI Finance Working Paper No. 139/2006, available at http://ssrn.com/abstract=948907 (2006), presents complementary evidence for a longer time series of hedge fund activism (see especially Tables 5-7). In another sample covering roughly the same time period, William W. Bratton, Hedge Funds and Governance Targets, 95 Geo. L.J. 1375, 1405 (2007), also finds that hedge funds appear to play relatively activist roles in target firms, and that they exhibit a high level of success with respect to their proposals.

297 Though as pointed out in Rock, supra note _, at 479-480, in some cases mutual fund and pension managers will indeed find it in their self interest to engage in monitoring and activism.

298 See Brad M Barber, Terrance Odean, \& Lu Zheng, Out of Sight, Out of Mind: The Effect of Expenses on Mutual Fund Flows, 78 J. of Bus. 2095, 2102 Table 1 (2005), which provides expense ratios for a large sample of diversified U.S. equity funds. Management fees are a subset of expenses, so the numbers presented here are upper bound estimates.

299 See William N. Goetzmann, Jonathan E. Ingersoll, Jr., \& Stephen A. Ross, High Water Marks and Hedge Fund Management Contracts, 58 J. Fin. 1685, 1685-1686 (2003).

300 In fact, it is common for the hedge fund managers themselves to have a significant portion of their own capital invested in the fund. See Erik J. Greupner, Comment: Hedge Funds Are Headed Down-Market: A Call for Increased Regulation, 40 San Diego L. Rev. 1555, 1559 (2003).

301 See Bhagat \& Romano, supra note _, at 46-49, 61-70, 106-108 (Table 3) (surveying the literature). 
takeover attempt itself or (b) the accumulation of shares by a bidder in advance of announcing the bid. ${ }^{302}$ We can exclude (a) because the Hershey sale was not instigated by an outside party and the observed price appreciation largely disappeared once the sale was abandoned for exogenous reasons. ${ }^{303}$ We can exclude (b) because the attempted takeover of the Hershey Company was invited by the Trust, before a prospective outside bidder would have begun buying shares to obtain a toehold in the Company. 304

Like other existing studies of share price movement on news of a takeover, we cannot rule out the possibility that the observed appreciation was driven by a capitalized control premium or expected synergies between Hershey and the eventual acquirer. However, compared to the existing studies, these effects should be attenuated in our study because the takeover announcement came from the target before a buyer had been identified. The existence of a bidder-specific control premium or synergy was therefore uncertain when news of the trustees' plan to sell broke.

Although we improve on the existing literature in the forgoing ways, we nonetheless characterize our contribution to the takeover literature as modest for two reasons. First, given the possibility that the Trust might have imposed something other than wealth maximization on the Company's managers, we cannot exclude the possibility that the observed price movement represents the market's expectation of a shift in management objective rather than the containment of corporate agency costs. In other words, our results may reflect only charitable trust agency costs. Second, our study is by necessity limited to a single firm. Given these limitations, the existing literature, which includes a host of multiple-firm takeover studies, supplies crucial interpretive context for our findings. When multiple studies using different research designs with different strengths and weaknesses produce similar results, confidence in the general validity of those results increases. ${ }^{305}$

302 Further, relative to studies that examine changes in state takeover law, our results do not suffer from the potential omitted variables bias inherent in such studies. Changes in state takeover laws may themselves be the result of broader changes in the state's business climate.

303 Although others have found that takeover premiums tend to disappear after a takeover is abandoned, see, e.g., Michael Bradley, Anand Desai, and E. Han Kim, The Rationale Behind Interfirm Tender Offers: Information or Synergy, 11 J. Fin. Econ. 183 (1983), it is difficult to rule out the possibility that a takeover is abandoned for reasons that are germane to firm value such as a downward revision of expected future profit streams or the implementation of a new takeover defense. In our case, this endogeneity problem may be ruled out because the sale was abandoned for reasons unrelated to the Hershey Company's underlying business prospects.

${ }^{304}$ For a discussion of the role of upward sloping supply curves for shares in a target firm as a determinant of takeover premiums, see Michael Bradley, Anand Desai, and E. Han Kim, Synergistic Gains from Corporate Acquisitions and Their Division Between the Stockholders of Target and Acquiring Firms, 21 J. Fin. Econ. 3 (1988). For evidence of this possibility generally, see Andrei Shleifer, Do Demand Curves for Stocks Slope Down?, 41 J. Fin. 579 (1986), though the notion of non-horizontal demand curves for equities is controversial in both law and finance. This debate has also been touched on in the case law. See, e.g., West v. Prudential Securities, 282 F.3d 935, 939 (7th Cir. 2002) (Easterbrook, J.).

305 Cf. Roberta Romano, The Need for Competition in International Securities Regulation, 2 Theo. Inq. L. 387, 505-06 (2001). 


\section{CONCLUSION}

This paper uses the aborted 2002 sale of the Hershey Company by the Hershey Trust as a quasi-natural experiment to investigate theoretical claims in the literatures of trust law and corporate law. In so doing, this paper makes fresh contributions to both literatures, and it also contributes to the technical literature on event study methodology.

Trust Law. Our analysis provides the first quantitative empirical assessment of the prevailing scholarly view that agency costs are rampant in charitable trusts. Because a charitable trust must be for the benefit of a charitable purpose, not an identifiable beneficiary, there is no one with both an economic interest and legal standing to ensure that the trustee efficiently pursues the trust's charitable purpose. Although the state attorneys general have formal authority to enforce charitable trusts, the attorney general is typically a political official for whom supervision of such trusts has little political payoff.

Our findings imply agency costs in the high-profile, politically salient Hershey Trust on the order of $\$ 850$ million (about 15 percent of the 2002 value of the Trust). Moreover, instead of reducing the agency costs associated with the Trust's charitable trust form, the attorney general's intervention to block the Trust's sale of the Hershey Company made those agency costs permanent. To be sure, we do not claim that all charitable trusts host the same magnitude of agency costs as the Hershey Trust. Nor do we claim that all interventions by state attorneys general are as maladroit as the intervention here. Instead our claim is that our results tend to validate the assumption in the theoretical literature, heretofore based chiefly on qualitative anecdotal evidence, of the prevalence of agency costs in charitable trusts and the failure by the state attorneys general adequately to superintend such trusts. Accordingly, our analysis throws light on current policy debates in trust law such as (1) alternative modes of supervision for charitable trusts, (2) expanding the cy pres doctrine to address excess endowments, and (3) the propriety of social investing by trustees.

Corporate Law. Agency costs are the central concern of the study and practice of corporate law. The difficult task is to align the incentives of managers with the interests of shareholders, or at least to constrain the extent to which managers can advance their own interests at the expense of shareholders. A growing empirical literature suggests that the takeover threat posed by exposure to the market for corporate control and monitoring by controlling shareholders or large blockholders are among the most powerful levers available to induce managers to act in the best interests of shareholders. Our analysis contributes to this literature by suggesting that, at least in the case of the Hershey Trust and Hershey Company, the takeover threat provided more managerial discipline than the presence of a controlling shareholder. ${ }^{306}$ Although we cannot disentangle the role of the Trust's weak internal governance structure from the role of switching from a controlling shareholder to the

306 We consider the potentially conflating influences of a capitalized control premium or expected synergies in the text following supra note 304 . 
takeover market as alternative explanations for this finding, our results nonetheless highlight the need to consider the incentives of a blockholder's agents when analyzing the efficacy of relying on the blockholder to police managerial agency costs. The $\$ 2.7$ billion increase in the value of the Hershey Company on exposure to the takeover market is a damning indictment of the trustee's failure as agents of the Trust to maximize value.

Financial Econometrics. Although the event study technique is a wellaccepted tool of financial econometrics, and single-firm event studies appear in the academic literature and are routinely employed in securities litigation, ${ }^{307}$ such a study poses special problems on account of the increased volatility associated with a portfolio of one. The concern is that a single firm's observed abnormal returns might not be normally distributed, and if so, that we might attribute statistical significance to an abnormal return that in fact reflects only random variation. To address this worry, we develop and present a method of assessing statistical significance that uses an empirical distribution of abnormal returns based on randomization inference as a substitute for using the critical values for statistical significance from the standard normal distribution. This randomization inference technique has been used in other applications outside of financial economics, and it bears a similarity to recently-developed bootstrapping methods, but we believe that we are the first to use it in an event study in the law and economics literature. Because the technique can easily be implemented in most single-firm event studies, and because it improves confidence in assessments of statistical significance, we commend its use in future single-firm event studies.

307 See supra notes 251-252. 


\section{APPENDIX A: EXTENDEd PRICE DyNAMIC GRAPHS}

Figure A1:

HSY Price History

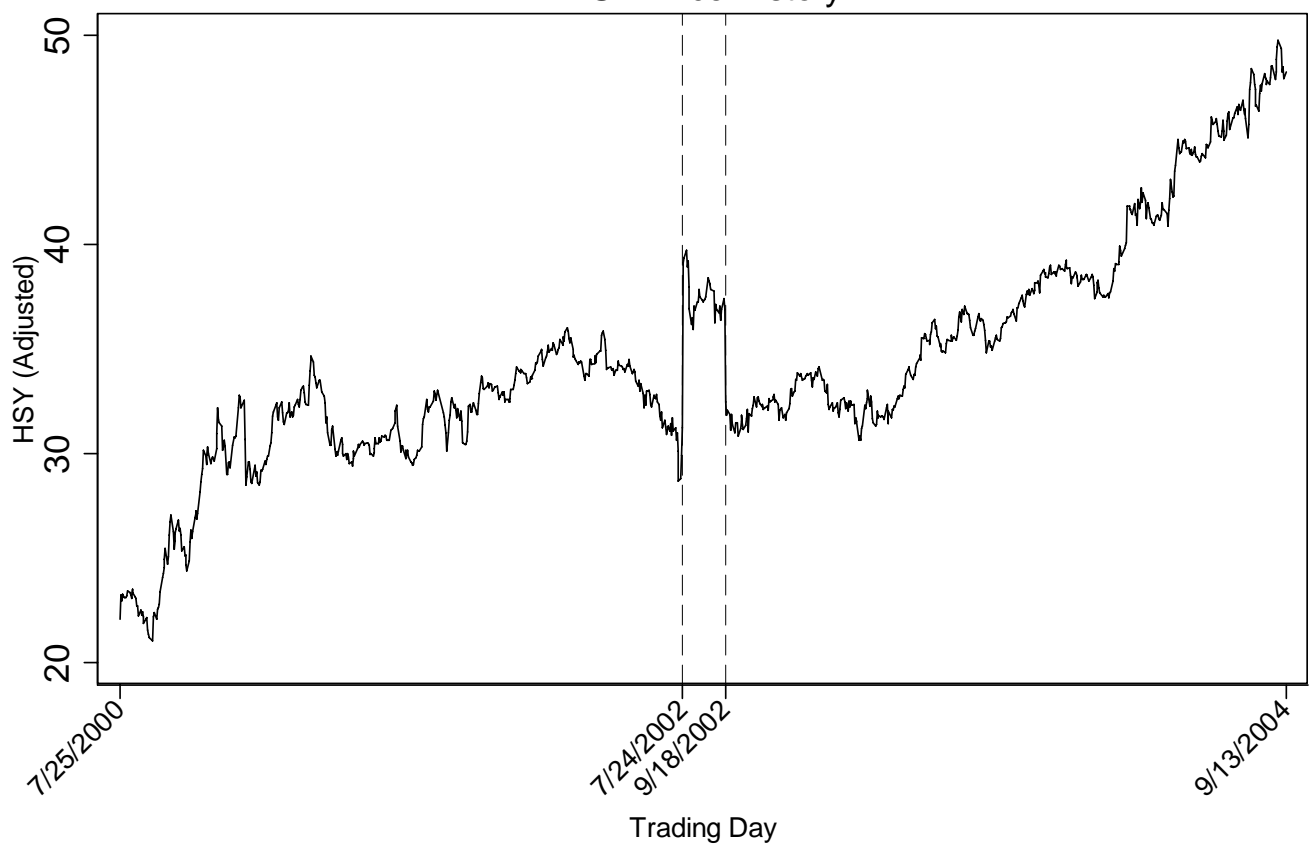

Figure A2:

HSY vs. Chocolate Competitors

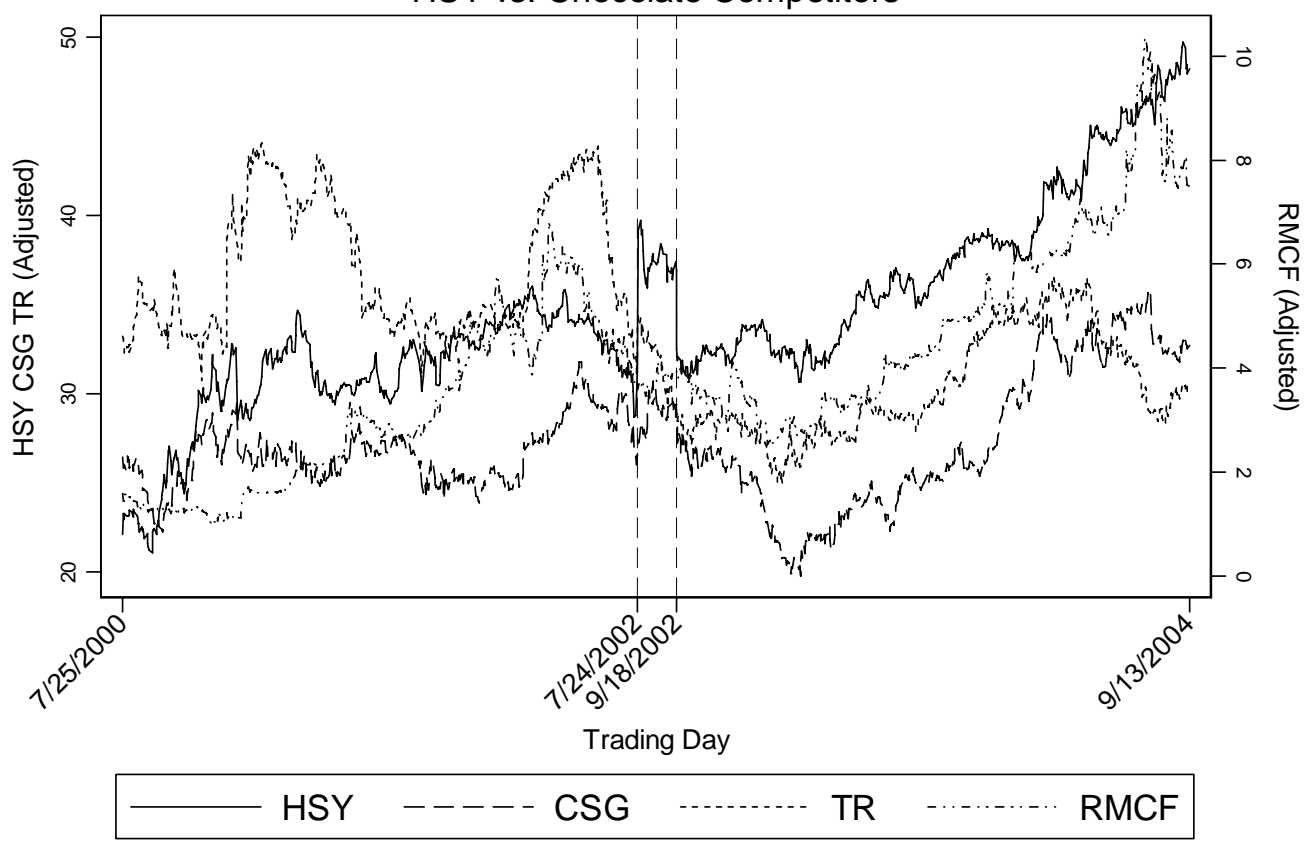


Figure A3:

HSY vs. Food Competitors

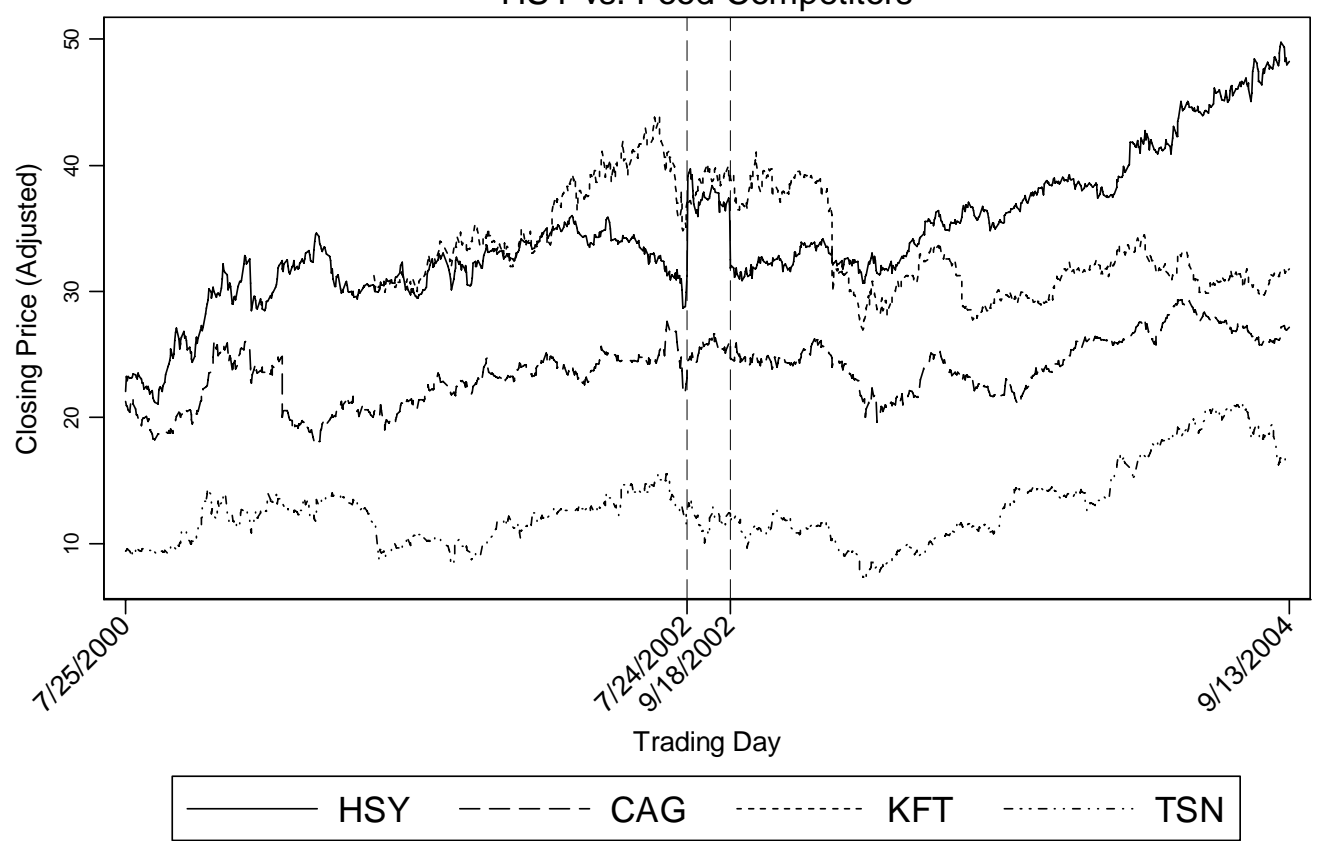

Figure A4a:

HSY vs. S\&P 500

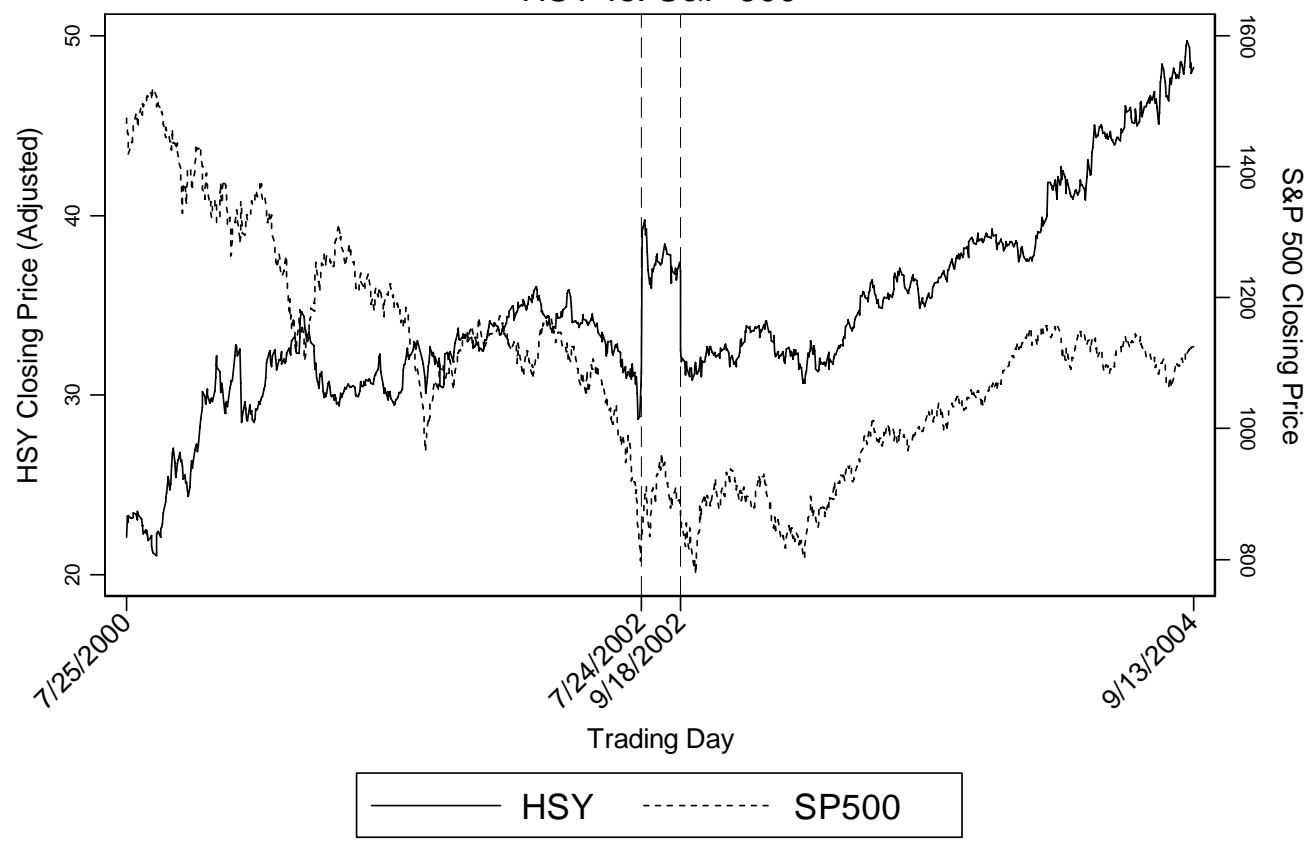


Figure A4b:

HSY vs. Dow Jones Industrial Average

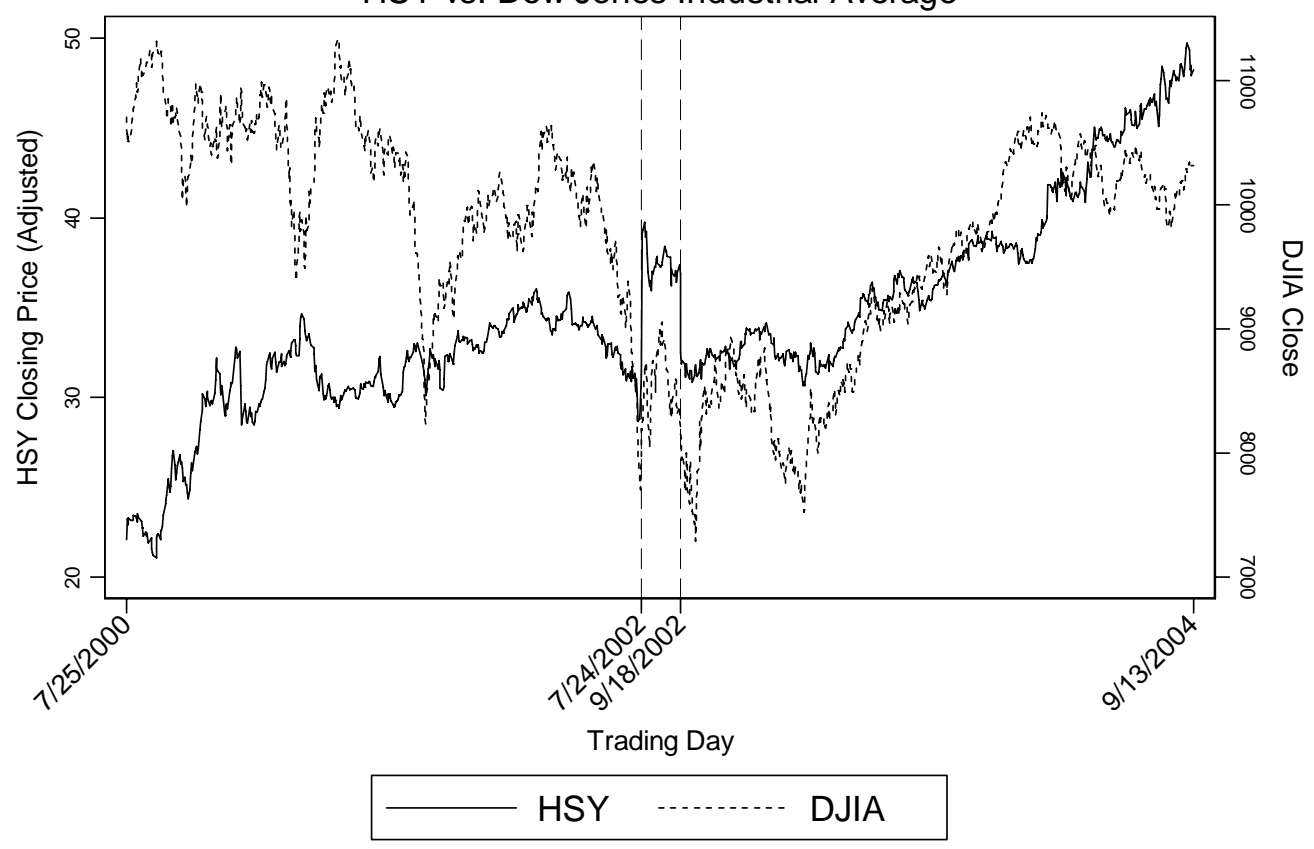




\section{APPendix B: The Possibility of Leakage}

A concern in event studies is the possibility that insiders might use their advance knowledge of a pending material announcement to trade for their own gain or for the benefit of third parties. ${ }^{308}$ In the present case, the possibility of leakage would suggest that HSY may have started to appreciate in a non-random way before the July 25, 2002 sale announcement. If the price of HSY started climbing earlier as a result of leakage trading, our measure of the abnormal return associated with the sale is underestimated. Such a scenario is consistent with the depiction of cumulative abnormal returns in Figure 5a. To examine the possibility of leakage more formally, we present the abnormal returns for the ten days before and after the sale window in Appendix Table B1. 309

Appendix Table B1

Evidence of Leakage Before Sale Announcement

\begin{tabular}{lllll}
\hline Date & Actual & Expected & Abnormal & $\begin{array}{l}\text { Standardized } \\
\text { Abnormal }\end{array}$ \\
\hline Pre Sale Window & & & & \\
\hline $7 / 11 / 2002$ & 0.027 & 0.001 & 0.026 & $2.737^{\star \star}$ \\
$7 / 12 / 2002$ & -0.021 & -0.002 & -0.019 & $-2.000^{\star}$ \\
$7 / 15 / 2002$ & 0.006 & -0.002 & 0.007 & 0.737 \\
$7 / 16 / 2002$ & -0.020 & -0.005 & -0.015 & -1.579 \\
$7 / 17 / 2002$ & 0.013 & 0.000 & 0.012 & 1.263 \\
$7 / 18 / 2002$ & -0.029 & -0.007 & -0.022 & $-2.316^{\star}$ \\
$7 / 19 / 2002$ & -0.048 & -0.009 & -0.039 & $-4.105^{\star \star \star}$ \\
$7 / 22 / 2002$ & 0.004 & -0.008 & 0.012 & 1.263 \\
$7 / 23 / 2002$ & 0.039 & -0.007 & 0.045 & $4.737^{\star \star \star}$ \\
$7 / 24 / 2002$ & 0.045 & 0.012 & 0.033 & $3.474^{\star \star \star}$ \\
\hline Post Sale Window & & & -1.263 \\
\hline $9 / 19 / 2002$ & -0.020 & -0.007 & -0.012 & 0.737 \\
$9 / 20 / 2002$ & 0.007 & -0.000 & 0.007 & -0.316 \\
$19 / 23 / 2002$ & -0.006 & -0.004 & -0.003 & -1.895 \\
$9 / 24 / 2002$ & -0.023 & -0.005 & -0.018 & -0.105 \\
$9 / 25 / 2002$ & 0.003 & 0.005 & -0.001 & 1.789 \\
$9 / 26 / 2002$ & 0.020 & 0.003 & 0.017 & -0.737 \\
$9 / 27 / 2002$ & -0.015 & -0.008 & -0.007 & -0.842 \\
$9 / 30 / 2002$ & -0.012 & -0.004 & -0.008 & 0.737 \\
$10 / 1 / 2002$ & 0.015 & 0.008 & 0.007 & 0.632 \\
$10 / 2 / 2002$ & 0.000 & -0.006 & 0.006 & \\
\hline \hline
\end{tabular}

Note: ${ }^{\star \star \star} p<0.001 ;{ }^{\star \star} p<0.01 ;{ }^{\star} p<0.05$ (i.e., abnormal return is statistically significant at the $0.1 \%, 1 \%$, and $5 \%$ levels respectively).

308 Under semi-strong form market efficiency, stock prices reflect all public information, so there are potential gains from trading on nonpublic information.

309 Because in Appendix Table B1 we examine the 10 trading days prior to the July 25 sale announcement, in estimating expected returns we used 100 trading days prior to those 10 days as our estimation period. In Table 3, by contrast, we used the 100 trading days prior to July 25 for our estimation period. The results in Table 3 would not change, however, if we used the same estimation period as in Appendix Table B1. 
We do find some evidence of leakage during the two trading days prior to the sale announcement, as the abnormal returns for those days were about 5 and 3 percent respectively, both statistically significant at the 0.1 percent level. If these abnormal positive returns indeed represent leakage, our original measure of the effect of the sale announcement is underestimated by about 8 percent. However, our confidence in this evidence of leakage is weak, as the price movements during the 10 day pre sale window appear to be especially volatile. Given the large negative abnormal returns earlier in the 10 day period before the sale announcement, the positive abnormal returns on the two days prior to the sale announcement could simply represent reversion to the mean. ${ }^{310}$ Moreover, on July 23 the Company issued a positive earnings announcement, ${ }^{311}$ which further undermines our confidence in inferring leakage trading from the July 23 and 24 abnormal returns. Accordingly, in the main text we do not increase our estimate of the abnormal return associated with the sale announcement to account for the possibility of leakage.

We observe no significant abnormal returns in the 10 day period after the sale window.

310 These results bring into view the related concern of volatility in a one-firm event study. We address the problem of a one-firm event study in supra Part III.C.4.

311 See Herhsey’s Net Rises 20\% Despite a Strike, Wall St. J. A10 (July 24, 2002). 


\section{APPENDIX C: How UNLIKELY ARE THE ABNORMAL RETURNS?}

Hypothesis testing in econometrics involves comparing a test statistic to critical values for statistical significance that are chosen from the standard normal distribution. This is the method implied by the discussion in supra Part [crossreference]. However, use of the standard normal distribution assumes the applicability of a central limit theorem, which holds that the sample average of abnormal returns converges to the standard normal distribution, regardless of the population distribution. ${ }^{312}$ Unfortunately, in our study we have relatively few sample draws arising from the sale "shock" (and, arguably, those draws are not independent of each other), which limits our ability to rely on a central limit theorem. ${ }^{313}$

However, for our primary results of interest (i.e., the abnormal return on the day the sale was announced and the abnormal return on the day the sale was abandoned), it turns out that the observed abnormal returns are so large that they would rarely occur by chance under any feasible distribution of abnormal returns. That is, we do not need to rely on a central limit theorem or on any assumptions about the underlying "true" distribution of abnormal returns for Hershey to have confidence that it is unlikely that the observed abnormal returns were simply the result of normal variation in returns.

This claim hinges on the Chebyshev inequality, ${ }^{314}$ which states that:

$$
\operatorname{Pr}\left(\left|\frac{x-\mu}{\sigma}\right|>\alpha\right) \leq \frac{1}{\alpha^{2}}
$$

In our application, $x$ is the observed abnormal return, $\mu$ is the hypothesized value (i.e., 0 ), and $\sigma$ is the standard deviation of observed abnormal returns, making the entire argument inside of the absolute value operator equivalent to our standardized abnormal return. Thus, for our purposes, Chebyshev's inequality states that the probability that the absolute value of a standardized abnormal return is greater than some arbitrary value $\alpha$ is less than or equal to one over $\alpha$ squared. Crucially, Chebyshev's inequality holds for any possible distribution, which means that a claim of statistical significance derived from it does not require any assumptions about the generation of the underlying data or convergence via a central limit theorem.

Applied to our data, Chebyshev's inequality implies that the likelihood of observing the standardized abnormal return associated with the day the Hershey sale was announced (21.250) by random coincidence is less than or equal to 0.0022. For the abnormal return observed on the day the preliminary injunction was announced

312 See, e.g., William H. Greene, Econometric Analysis 116-118 (4th ed. 2000); James H. Stock \& Mark W. Watson, Introduction to Econometrics 52-55 (2d ed. 2007).

313 See Jack Johnston and John DiNardo, Econometric Methods 55 (4th ed. 1997).

314 See Russell Davidson and James G. MacKinnon, Estimation and Inference in Econometrics 799-800 (1993). 
(3.917), the likelihood of observing this by chance is less than or equal to 0.0652 . Finally, the likelihood associated with the abnormal return on the day the sale was abandoned (9.833) is less than or equal to 0.0103 . 